Universidade de São Paulo

Faculdade de Medicina de Ribeirão Preto

Harnôldo Colares Coêlho

\title{
PRESENÇA DOS VÍRUS HBV E HCV E SEUS FATORES DE RISCOS NOS PRESIDIÁRIOS MASCULINOS DA PENITENCIÁRIA DE RIBEIRÃO PRETO
}

Ribeirão Preto

2008 


\section{Harnôldo Colares Coêlho}

\section{PRESENÇA DOS VÍRUS HBV E HCV E SEUS FATORES DE RISCOS NOS PRESIDIÁRIOS MASCULINOS DA PENITENCIÁRIA DE RIBEIRÃO PRETO}

Tese apresentada à Faculdade de Medicina de Ribeirão Preto da Universidade de São Paulo para obtenção do Título de Doutor.

Área de Concentração: Clínica Médica.

Orientador: Prof. Dr. José Fernando de C.

Figueiredo

Ribeirão Preto

2008 


\section{FICHA CATALOGRÁFICA}

Coêlho, Harnôldo Colares.

Presença dos vírus HBV e HCV e seus fatores de riscos nos presidiários masculinos da Penitenciária de

Ribeirão Preto. Ribeirão Preto, 2008.

121 p.: il.; $30 \mathrm{~cm}$

Tese de Doutorado apresentada à Faculdade de Medicina de Ribeirão Preto - Universidade de São

Paulo - Área de concentração: Clínica Médica.

Orientador: Prof. Dr. Figueiredo, José Fernando de Castro.

1. Hepatite B. 2. Hepatite C. 3. Prisões.

4. Prevalência. 5. Fatores de Risco. 
Às minhas filhas, Clara e Cecília, pela alegria irradiada contínua e estímulo a tornar-se melhor.

À minha esposa, Raquel, por ser minha âncora, meu porto seguro e fonte do mais sincero amor. 


\section{AGRADECIMENTOS}

Ao Prof. Dr. José Fernando de Castro Figueiredo por sua orientação através de dedicação, disponibilidade, paciência, objetividade, serenidade e amizade.

Ao Prof. Dr. Afonso Dinis Costa Passos que foi o início de tudo isso, por sua atenção, amizade e eterna orientação.

À Profa. Dra. Gleici Perdoná pelo seu ardoroso empenho na realização da análise estatística.

Ao Programa de DSTIAIDS da Secretaria de Saúde de Ribeirão Preto pelo financiamento do material de coleta.

À direção da Penitenciária de Ribeirão Preto por dar permissão à realização deste trabalho, principalmente o Dr. Maurici Antonio Turnes, exchefe da divisão médica.

À auxiliar de enfermagem Maria do Carmo Prado Logarezi e à enfermeira Maria do Carmo Coutinho de Oliveira por participarem ativamente na coleta de sangue dos presidiários.

Às funcionárias do laboratório de sorologia do HCRP Margarida Maria Passeri e Maria Helena Malta pelo grande auxílio na centrifugação de todo material coletado.

Ao Laboratório de Referência Nacional para Hepatites Virais do Departamento de Virologia do Instituto Oswaldo Cruz da FIOCRUZ na pessoa da Dra. Maria de Lourdes Aguiar Oliveira, responsável pela realização dos exames sorológicos. 
À funcionária da pós-graduação Rossana Minghelli Ribeiro por sua competência e atenção.

Aos amigos Profs. Marta Edna e Juan Stuardo Rocha pela permanente amizade e atenção desde sempre.

Aos colegas e amigos Valdes Roberto Bollela e Anna Christina Tojal pelo incentivo e apoio incondicional.

Aos amigos e primos Keny Colares e Danielle Malta que deixaram enorme saudade e maravilhosas lembranças.

Ao grupo de agentes penitenciários da Penitenciária de Ribeirão Preto pela colaboração à realização deste trabalho.

Aos presidiários participantes que tornaram este trabalho em realidade. 


\section{RESUMO}

COELHO, H.C. Presença dos vírus HBV e HCV e seus fatores de riscos nos presidiários masculinos da Penitenciária de Ribeirão Preto. 2008. 121p. Tese de Doutorado. Faculdade de Medicina de Ribeirão Preto, Universidade de São Paulo, Ribeirão Preto - SP.

Infecções pelos vírus da hepatite B (HBV) e vírus da hepatite C (HCV) na população prisional apresentam prevalências bastante elevadas, alcançando taxas, algumas vezes, de mais de 40\%. Contribuem para isso diversos comportamentos de risco, adotados já antes do encarceramento ou desenvolvidos durante o período de reclusão. Entre eles, destacam-se o uso de drogas ilícitas intravenosas com compartilhamento de agulhas, tatuagens e atividade sexual desprotegida. Esta pesquisa objetivou estimar a prevalência dos marcadores do HBV e HCV com seus respectivos fatores de risco para estas exposições na população masculina carcerária da Penitenciária de Ribeirão Preto - SP, no período de maio a agosto de 2003. Do total de 1030 presidiários, foram sorteados 333 participantes por amostragem casual simples, os quais foram submetidos à aplicação de um questionário padronizado e tiveram coletada uma amostra de sangue. Para diagnóstico do HBV e HCV foi utilizado o ensaio imunoenzimático para detecção do HBsAG, anti-HBc total, anti-HBs e anti-HCV. A confirmação deste foi feita através de reação de polimerase em cadeia (HCV RNA). As prevalências encontradas para $\mathrm{HBV}$ e $\mathrm{HCV}$ nos presidiários foram de 19,5\%\% (IC 95\%: 15,2 - 23,8) e 8,7\% (IC 95\%: 5,7 - 11,7), respectivamente . Todas as variáveis que apresentaram "p" abaixo de 0,25 , através de análise univariada, foram submetidas a um modelo multivariado de regressão logística. Nesta análise, as variáveis que se mostraram preditoras de forma independente da infecção pelo HBV foram: idade acima de 30 anos e passado de droga injetável. Já para o HCV, as variáveis foram idade acima de 30 anos, história prévia de hepatite, tatuagem, passado de droga injetável e passado de compartilhamento de agulhas.

Palavras-chave: 1. Hepatite B; 2. Hepatite C; 3. Prisões; 4. Prevalência; 5. Fatores de risco. 


\section{ABSTRACT}

COELHO, H.C. Prevalence and risk factors for HBV and HCV infection in male prisoners in Ribeirão Preto. 2004. 121p. Tese de Doutorado. Faculdade de Medicina de Ribeirão Preto, Universidade de São Paulo, Ribeirão Preto - SP.

The hepatitis B virus (HBV) and hepatitis C virus (HCV) infections in correctional settings have quite high prevalences, reaching rates of up to $40 \%$. Several risk behaviors, adopted before or during the imprisonment, accounts for that. Among them, the use of intravenous illicit drugs, sharing of needles, tattoos and unprotect sexual activity are the most important. This survey aimed to estimate the prevalence of HBV and HCV serological marker and risk factors for these infections in men inmates at the Penitentiary of Ribeirão Preto, State of São Paulo, Brazil, between May and August 2003. Out of 1030 inmates, a simple random sample of 333 participants was chosen. The participants were interviewed in a standardized questionnaire and provided blood for serological tests. An enzyme-linked immunosorbent assay (ELISA) was used for diagnosis of $\mathrm{HBV}$ and $\mathrm{HCV}$ infection (HBsAg, anti-HBs, anti-HBc, anti-HCV). Polymerase chain reaction (HCV RNA) was used to confirm HCV infection. The overall prevalence for HBV and HCV markers in inmates was 19,5\% (Cl 95\%: 15,2 - 23,8) and 8,7\% (Cl 95\%: 5,7 $-11,7$ ), respectively. The variables that displayed $p<0,25$, through univariate analysis, were assessed by a logistic regression multivariate model. At the level of $5 \%$, HBV infection was associated with age $>30$ years and previous injecting drug use. For HCV infection, age > 30 years, previous injecting drug use, previous sharing of needles, tattoos and previous hepatitis.

Key words: 1. Hepatitis B; 2. Hepatitis C; 3. Prisons; 4. Prevalence; 5. Risk fators. 


\section{LISTA DE TABELAS}

Tabela 1- Distribuição dos presidiários nos pavilhões estudados e seus respectivos participantes.

Tabela 2- Valores da média, desvio padrão, mediana e amplitude de variação nos presidiários.

Tabela 3- Distribuição dos presidiários segundo idade e pavilhão...

Tabela 4- Distribuição dos presidiários segundo local de nascimento e pavilhão

Tabela 5- Distribuição dos presidiários segundo local de residência e pavilhão.

Tabela 6- Distribuição dos presidiários segundo estado civil e pavilhão.

Tabela 7- Distribuição dos presidiários segundo tipo de droga não injetável usada no passado e pavilhão.

Tabela 8- Distribuição dos presidiários segundo idade e uso de drogas ilícitas não injetáveis.

Tabela 9- Distribuição dos presidiários segundo idade e uso de drogas ilícitas injetáveis.

Tabela 10- Distribuição dos marcadores do HBV nos presidiários expostos.

Tabela 11- Distribuição dos marcadores do HCV nos presidiários......

Tabela 12- Distribuição dos presidiários segundo idade e infecção pelo HBV.

Tabela 13- Distribuição dos presidiários segundo escolaridade e infecção pelo HBV

Tabela 14- Distribuição dos presidiários segundo idade e infecção pelo HCV.

Tabela 15- Distribuição dos presidiários segundo escolaridade e infecção pelo HCV 
Tabela 16- Distribuição dos presidiários segundo tempo da pena total e infecção pelo HBV e HCV.

Tabela 17- Distribuição dos presidiários segundo tempo da pena cumprida e infecção pelo HBV e HCV

Tabela 18- Distribuição dos presidiários segundo DST prévia e infecção pelo HBV e HCV.

Tabela 19- Distribuição dos presidiários segundo preferência sexual e infecção pelo HBV e HCV

Tabela 20- Distribuição dos presidiários segundo uso de preservativo na visita íntima e infecção pelo $\mathrm{HBV}$ e $\mathrm{HCV}$

Tabela 21- Distribuição dos presidiários segundo já ter tido relações sexuais com usuária de drogas ilícitas e infecção pelo HBV e HCV

Tabela 22- Distribuição dos presidiários segundo passado de drogas não injetáveis e infecção pelo HBV e HCV

Tabela 23- Distribuição dos presidiários segundo uso de drogas ilícitas injetáveis no passado e infecção pelo HBV e HCV

Tabela 24- Distribuição dos presidiários segundo compartilhamento de agulha no passado e infecção pelo HBV e HCV.

Tabela 25- Distribuição dos presidiários segundo transfusão sanguínea no passado e infecção pelo HBV e HCV ..........

Tabela 26- Distribuição dos presidiários segundo passado de hepatite e infecção pelo HBV e HCV.

Tabela 27- Distribuição dos presidiários segundo antecedente de icterícia e infecção pelo HBV e HCV.

Tabela 28- Distribuição dos presidiários segundo tatuagem e infecção pelo HBV e HCV.

Tabela 29- Distribuição dos presidiários segundo infecção do HIV e infecção pelo HBV e HCV.

Tabela 30- Distribuição dos presidiários segundo infecção pelo HBV e infecção pelo HCV.

Tabela 31- Modelo de regressão logística para HBV.....

Tabela 32- Modelo de regressão logística para HCV. 


\section{SUMÁRIO}

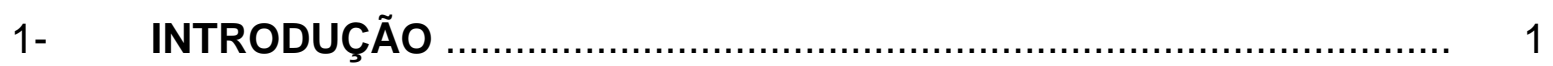

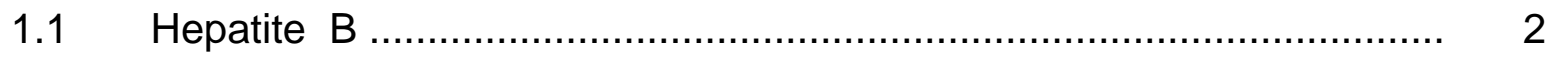

1.1.1 Prevalência do vírus da hepatite B ………...................................... 7

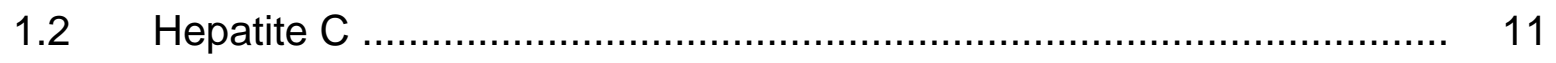

1.2.1 Prevalência do vírus da hepatite $C$................................................... 14

1.3 O sistema carcerário e as hepatites B e C ........................................... 16

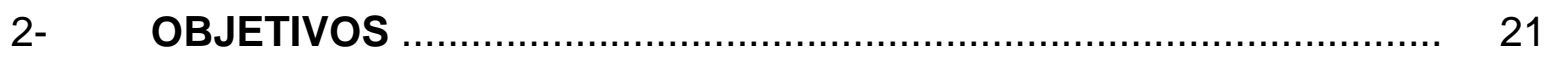

3- POPULAÇÃO, MATERIAL E MÉTODOS ...................................... 22

3.1 Modelo de Estudo ....................................................................... 22

3.2 Divisão da População Carcerária.......................................................... 22

3.3 População de Referência............................................................. 23

3.4 População de Estudo e Tamanho Amostral.......................................... 23

3.5 Critérios de Inclusão................................................................. 24

3.6 Critérios de Exclusão......................................................................... 24

3.7 Localização da Penitenciária e Local de Estudo.................................. 24

3.8 Coleta de Informações.............................................................. 25

3.9 Variáveis Estudadas Através do Questionário..................................... 25

3.10 Coleta de Sangue ................................................................. 31

3.11 Análise Sorológica............................................................... 32

3.12 Descrição dos Métodos Sorológicos................................................. 32

3.12.1 Métodos imunoenzimáticos ............................................................... 33

3.12.2 Método imunocromatográfico .................................................... 35

3.12.3 Método de reação de polimerase em cadeia ..................................... 36

3.13 Digitação e Organização dos Dados.................................................. 36

3.14 Análise Estatística.................................................................. 36

3.15 Aspectos Éticos................................................................... 36 
4- RESULTADOS

4.1 Aspectos Descritivos da População de Estudo............................. 37

4.2 Resultados do Estudo de Associação entre Positividade Sorológica ao HBV e HCV e Possíveis Fatores de Riscos respectivos.................... 45

4.2.1 Estudo do HBV com "faixa etária" e "escolaridade" isoladamente........ 47

4.2.2 Estudo do HCV com "faixa etária" e "escolaridade" isoladamente........ 49

4.2.3 Estudo do HBV e HCV em conjunto com outras varáveis................... 50

4.3 Análise Multivariada............................................................... 60

4.3.1 Co-variáveis relacionadas ao HBV.......................................... 61

4.3.2 Co-variáveis relacionadas ao HCV .............................................. 62

4.3.3 Análise multivariada para HBV............................................. 63

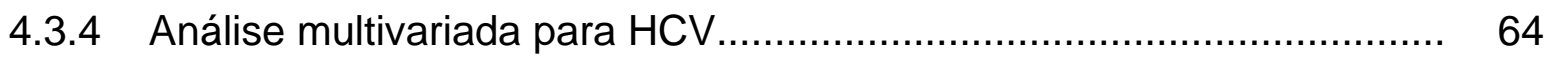

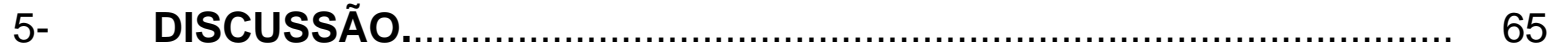

5.1 Considerações Gerais...................................................... 65

5.1.1 Divulgação da Pesquisa entre os Presidiários................................. 66

5.1 .2 Inclusão dos Participantes.................................................. 67

5.1.3 Acesso e Contato com os Presidiários......................................... 68

5.1.4 Considerações sobre Aplicação do Questionário............................ 70

5.1 .5 Coleta do Exame de Sangue..................................................... 71

5.2 Discussão dos Resultados........................................................ 71

5.2.1 Aspectos descritivos da população estudada................................ 71

5.2.2 Resultados do estudo de associação de marcadores do HBV e HCV com fatores de risco.......................................................... 77

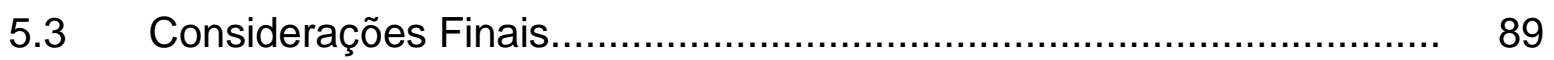

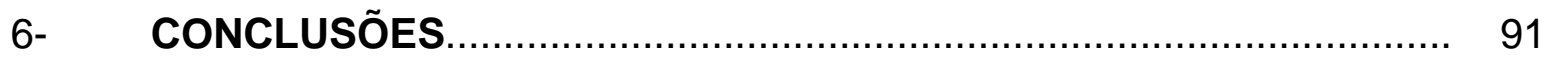

REFERÊNCIAS BIBLIOGRÁFICAS....................................... 92

APÊNDICE 1 - Termo de consentimento................................. 117

APÊNDICE 2 - Questionário........................................... 119 


\section{INTRODUÇÃO}

Existem vírus que, a partir de uma infecção sistêmica, podem acometer o fígado e originar uma hepatite. Em muitos casos, esta inflamação hepática somente é detectada em exames laboratoriais. Neste grupo de agentes etiológicos está o Cytomegalovirus, o vírus Epstein-Barr, o vírus da febre amarela entre outros. Mas há vírus que se desenvolvem nos hepatócitos, causando como manifestação predominante uma hepatite aguda. O termo hepatites virais está convencionalmente vinculado a esses vírus hepatotrópicos (FREITAS, 2003).

Relatos de surtos de icterícia remontam aos primórdios da civilização e estavam quase sempre associadas aos períodos de guerras. No ano 752 , o Papa Zacarias, em carta, alertava pela primeira vez para "uma icterícia de natureza contagiosa", recomendando a quarentena dos doentes e seus cavalos. Inúmeras epidemias de icterícia ocorreram com o passar dos séculos, mas vale destacar duas delas, estudadas, uma por Lürman e outra por Jehn, nas cidades de Bremen e Merzig, respectivamente, por volta de 1885 na Alemanha. Lürman - em trabalhadores de estaleiros - e Jehn - em detentos de um asilo - inocularam vacina para varíola preparada com linfa humana glicerinada e observaram enormes surtos de icterícia de longo período de incubação (REUBEN, 2002). A descrição da epidemia de Lürman, até hoje, é considerada como modelo de estudo epidemiológico de hepatite. Este estudo representa, retrospectivamente, o reconhecimento da exposição parenteral como potencial forma de transmissão de hepatite, sendo considerada, retrospectivamente, a primeira epidemia de hepatite $B$ que foi relatada (FREITAS, 2003).

Com base em estudos epidemiológicos, este tipo de infecção por contágio parenteral - denominada à época como hepatite sérica - se diferenciava daquela icterícia advinda das aglomerações de populações específicas, especialmente de soldados em guerras. Desta forma, alguns termos surgiram como "icterícia de campanha" e "doença do soldado" devido 
a epidemias surgidas durante batalhas e guerras que posteriormente passou a ser conhecida como doença de contágio fecal-oral, sendo denominada de hepatite infecciosa. Em 1947, Maccallum e Bauer propuseram a atual nomenclatura de hepatite A para hepatite infecciosa e hepatite B para a sérica (FREITAS, 2003). Estas evidências, que apontavam para dois tipos distintos de hepatite, foram confirmadas em um trabalho clássico, e polêmico, de Krugman, Giles e Hammond (1967), em que crianças internas de uma instituição para deficientes mentais eram submetidas à administração de material infeccioso, pelas vias parenteral e oral, à medida que davam entrada no local. Observando os resultados, comprovou-se a existência de dois vírus que causavam quadros clínicos e epidemiológicos diferentes e com características imunológicas próprias.

Atualmente, cinco vírus são apontados como os agentes causadores das hepatites virais: vírus da hepatite A (HAV), da hepatite B (HBV), da hepatite $C(\mathrm{HCV})$, da hepatite $D(H D V)$ e da hepatite $E(H E V)$. São conhecidas suas estruturas, formas de transmissão e gravidade da doença (FOCACCIA; BARALDO; SOUZA, 2003). Na presente pesquisa serão estudados os vírus da hepatites $\mathrm{B}$ e $\mathrm{C}$, sob ponto de vista epidemiológico.

\subsection{Hepatite B}

O vírus da hepatite B (HBV) - ou na verdade, um seu constituinte - foi descoberto, por acaso, por Blumberg, Alter e Visnich (1965) que descreveram uma imunoprecipitina presente no plasma de um paciente aborígene australiano com leucemia. Reconhecido como um antígeno, foi denominado "Austrália" e confirmado em trabalhos subseqüentes (GILES et al., 1969; PRINCE, 1968a,b).

O HBV é transmitido através de exposições percutânea e permucosa a sangue e outros fluidos corporais contaminados. As maiores concentrações do vírus são encontradas no sangue e secreções serosas, e em menor quantidade no sêmen, secreção vaginal e saliva. Atualmente, as formas predominantes de infecção pelo HBV são: uso de drogas ilícitas 
injetáveis, onde se compartilham agulhas e seringas, acidentes com agulhas em profissionais de saúde não vacinados e não imunizados, transmissão perinatal, transplante de órgãos ou tecidos, transfusão de sangue e derivados e atividade sexual. O antígeno de superfície do HBV (HBsAg) tem sido encontrado também nas fezes, urina, lágrimas, suor, leite materno, líquor, líquido sinovial, e no sangue do cordão umbilical (ROBINSON, 2000).

A presença do antígeno de replicação $(\mathrm{HBeAg})$ no soro relaciona-se com altos títulos do HBV e grande aumento da infectividade, tornando a transfusão de sangue e derivados a forma mais eficaz de contaminação (HINDMAN et al., 1976). Todavia, esta maneira de transmissão não tem grande relevância no cenário atual devido aos poucos casos advindos dos bancos de sangue, mas adquire certo grau de importância nos países do terceiro mundo, onde a qualidade de coleta do sangue não é a ideal (SCHMUNIS et al., 1998). Por outro lado, há relatos de transmissão do HBV em pacientes submetidos a transplantes de órgãos como rim e coração (LUNEL et al., 2000).

Os profissionais da saúde passaram a ser considerados um subgrupo populacional de maior risco para infecção pelo HBV do que a população em geral a partir década de 1970 (LEWIS et al., 1973; MOSLEY; EDWARDS; CASEY, 1975). Isto ocorre, sem dúvida por eles estarem mais expostos, especialmente os dentistas e cirurgiões, a pacientes infectados. A exposição ocupacional com agulha a partir de paciente fonte portador do HBV com HBeAg reagente acarreta até $30 \%$ de risco de contaminação. Já no portador com ausência do HBeAg, este risco varia de 1 a 6\% (WERNER; GRADY, 1982). Embora a inoculação acidental seja um excelente modo de transmissão, provavelmente esta forma seja minoria entre as infecções pelo HBV entre os profissionais de saúde. Em algumas investigações de surtos nosocomiais de hepatite $\mathrm{B}$, a maioria dos profissionais de saúde não se recordava de ter sofrido um acidente percutâneo evidente, contudo mais de um terço referia cuidar de pacientes portadores do HBsAg (CALLENDER; WHITE; WILLIAMS, 1982; CHAUDURI; FOLLET, 1982). A possibilidade dessa forma de transmissão foi demonstrada por Bond et al. (1981), pela 
presença do HBV em sangue ressecado, em temperatura ambiente, nas superfícies de materiais utilizados até uma semana após os procedimentos. Dessa forma, o contágio pelo HBV em profissionais de saúde vítimas de acidentes ocupacionais não pérfuro-cortantes, pode ser resultado de exposição direta ou indireta a sangue ou fluidos corporais infectados a partir de feridas, arranhões ou outras lesões, além de superfícies mucosas (FRANCIS; FAVERO; MAYNARD, 1981).

Apesar de aparentar reduzido risco, casos de transmissão do vírus da hepatite $B$ de profissionais de saúde para seus pacientes foram observados previamente na literatura (GRAF; MOESCHLIN, 1975; LEVIN; MADDREY; WANDS, 1974). Corroborando esses dados, na década de 1970 a prevalência da infecção pelo HBV na população de profissionais de saúde norte americana era dez vezes maior do que na população em geral (DENES et al., 1978). Com o advento da vacinação para hepatite B, estes tipos de relatos diminuíram, devido à imunização específica em massa indicada aos profissionais de saúde.

A transmissão perinatal por mães portadoras crônicas do HBV ou por mães com hepatite $B$ aguda no terceiro trimestre ou nos primeiros dois meses após o parto tem sido descrita nos Estados Unidos (EUA), assim como em populações com alta prevalência (ROBINSON, 2000). Okada et al. (1976) estimaram que 40 a 50\% dos portadores crônicos do HBV de Taiwan se infectaram no período perinatal. A transmissão da mãe para o filho pode ocorrer ainda no útero ou por intermédio de sangue ou fluidos orgânicos contaminados com o vírus da hepatite B ou durante o parto. Transmissão intra-útero é rara sendo estimada em $2 \%$ em um estudo realizado na China (XU et al., 1985). O risco da infecção perinatal está associado com a presença ou ausência, na mãe, do HBeAg (LEE et al., 2006). Se a mãe é reagente para o HBsAg e HBeAg, 70 a $90 \%$ dos seus filhos se tornarão infectados nos primeiros seis meses de vida (STEVENS et al., 1975), sendo que $90 \%$ destas crianças permanecerão cronicamente infectadas ( $X U$ et al., 1985). Já crianças nascidas de mães portadoras do HBeAg não reagentes têm de 10 a 40\% de risco de se tornarem infectadas e, destas, 40 a 70\% 
continuarão portadoras crônicas. As crianças filhas de mães $\mathrm{HBeAg}$ negativas, que não se contaminaram durante o período perinatal, tiveram risco de $40 \%$ de se infectarem até os cinco anos de idade (XU et al., 1985).

Mudanças no padrão do comportamento humano estão associadas a agravos na saúde dos indivíduos. Um exemplo clássico é a introdução de seringas - pelos usuários de drogas injetáveis (UDI) - para administração de substâncias ilícitas por via endovenosa, onde se compartilham as agulhas levando a disseminação de doenças. Uma vez introduzido o vírus da hepatite $\mathrm{B}$ em uma comunidade de UDI, há disseminação rápida da infecção entre seus componentes, com uma alta eficácia de transmissão. Além de atuar de forma direta na transmissão do vírus, sabe-se que as drogas injetáveis levam também a prática de sexo inseguro. Observou-se que esta inter-relação (drogas-sexo), devia-se a comportamento sexual de maior risco, como atividades sexuais com múltiplos parceiros ou diminuição dos cuidados de proteção durante a relação sexual, ou seja, a não utilização de preservativos (LEWIS; WATTERS; CASE, 1990). Dessa forma, o uso de drogas ilícitas endovenosas é importante fator de risco para difusão do HBV, sendo responsável por $17 \%$ dos 73.000 novos casos de hepatite $B$ ocorrido nos Estados Unidos (EUA), no ano de 2000 (CDC, 2002).

Mesmo em uma convivência domiciliar habitual, o risco de infecção do HBV por contato não parenteral é mais comum, a partir do portador do vírus. (HEATHCOTE; GATEAU; SHERLOCK, 1974; HERSCH et al., 1971). Existe presença do HBsAg na secreção vaginal, sêmen e saliva, embora sua concentração seja menor do que no soro do portador (DARANI; GERBER, 1974; HEATHCOTE; CAMERON; DANE, 1974). Conseqüentemente, uma das principais formas de contaminação pelo HBV na forma permucosa é a relação sexual, sendo que os homens que fazem sexo com homens são uma das populações de práticas sexuais de maior risco. Nestes indivíduos, o contágio está associado a relação anal receptiva e ao grande número de parceiros. Outro fator de risco importante é o número de anos de atividade sexual, onde $70 \%$ destes homens que têm relação com mesmo sexo estão infectados após cinco anos de práticas sexuais. Por conseguinte, homens 
que fazem sexo com homens apresentam taxas de prevalências ao HBV de 10 a 15 vezes mais elevadas do que nos pacientes heterossexuais ou doadores de sangue (ALTER; MARGOLIS, 1990).

De maneira análoga, os indivíduos heterossexuais masculinos e femininos também têm como fatores associados à infecção pelo vírus da hepatite $\mathrm{B}$ o número de parceiros sexuais, o número de anos de atividade sexual e, ainda, história prévia de doenças sexualmente transmissíveis (DSTs). (ALTER; MARGOLIS, 1990).

No entanto, não há fatores de riscos evidentes para contaminação em cerca de 20 a $30 \%$ dos portadores do vírus B. Isso ocorre, talvez, por relutância dos pacientes em assumir comportamentos de riscos ou existam outras vias de transmissão desconhecidas (LEE, 1997). Evidências apontam para infecções pelo vírus B por meio de contatos íntimos, principalmente em familiares, entre pessoas. Transmissão horizontal de criança a criança é reconhecida como uma dessas formas, apesar de ainda não se saber com exatidão como ocorre (LEE, 1997). Acredita-se que lesões de continuidade cutâneas associadas a contato íntimo representem um papel fundamental nesse modo de transmissão (KIFFER; VIANA; CHEINQUER, 2003). Comportamento inerente ao estilo de vida dos adolescentes em geral também representa risco mais elevado de aquisição do HBV (MEHEUS, 2000).

Ainda que alguns utensílios pessoais como escova de dente, lâmina de barbear, agulha, brinquedo, e outros, possam mediar à transmissão pessoa a pessoa, não há envolvimento habitual de alimentos e água (ROBINSON, 2000). Outras situações de exposição ao vírus da hepatite B têm sido descritas em indivíduos que se submeteram a tratamento com agulhas de acupuntura (KENT et al., 1988) e a tatuagens (LIMENTANI et al., 1979). Formas mais raras de contaminação pelo HBV são relatadas. Johnson e Hepatits B Outbreak Investigation Team (2000) descreveram em Toronto, um surto de hepatite $B$ em pacientes que frequentavam clínica neurológica, causado por eletrodos - aplicados abaixo da derme reutilizados em exames de eletroencefalograma. Em outra situação de 
infecção atípica, Redd et al. (2007) relataram transmissão do HBV - em consultório odontológico - de um paciente a outro que foi atendido cerca de duas horas e meia depois. Por último, Rosenheim et al. (2006) identificaram vírus idênticos em pacientes que realizaram biópsia endomiocárdica transvenosa.

Apesar da área da saúde ter praticamente eliminado a transmissão do HBV por transfusões de derivados do sangue, o risco ainda persiste por inadequação de esterilização de instrumentos médicos reutilizáveis e reutilização de materiais descartáveis (CDC, 2005). Exposições a seringas e agulhas utilizadas em tratamento médico são comuns em países, especialmente os subdesenvolvidos, por vários motivos: ausência de normas de biosegurança para controle de infecções; ausência de recursos para esterilização de materiais e para compra de equipamentos descartáveis; e preferências culturais favorecendo o uso de medicações injetáveis em detrimento a via oral (SHEPARD et al., 2006).

Presença do HBsAg em equipamento de diálise predipõe a um risco excepcional de contaminação do vírus da hepatite B aos pacientes (WONG et al., 2005). A transmissão do HBV entre os pacientes de hemodiálise está associada com a presença de pacientes cronicamente infectados, à ausência de isolamento destes pacientes em salas com equipamento e equipe individualizados, e à falência na cobertura vacinal a todos que se submetem à diálise (ALTER, 2003b).

\subsubsection{Prevalência do vírus da hepatite B}

Com grande disseminação em todo planeta, a hepatite $B$ já atingiu dois bilhões de pessoas no mundo - um terço dos habitantes - e por volta de 400 milhões de indivíduos estão cronicamente infectados (LAl et al., 2003). A cada ano, mais de um milhão de pessoas morrem de doença hepática crônica causada pelo vírus da hepatite $B$, incluindo cirrose e carcinoma hepatocelular (ALTER, 2003a). O carcinoma hepatocelular é uma das neoplasias mais prevalentes em todo mundo e sua etiologia, em $75 \%$ dos casos, está relacionado ao HBV (BEASLEY, 1988). 
A importância da forma de transmissão do vírus da hepatite $B$, no geral, varia de acordo com a taxa de prevalência em determinada região. Nas áreas de grande endemicidade ( 70 a $90 \%$ da população com contato prévio ao HBV), o risco de adquirir a infecção durante a vida é maior do que $60 \%$, e a contaminação ocorre, em sua grande maioria, durante o período perinatal, a partir de mães portadoras. Estas áreas englobam países que apresentam prevalência do HBsAg igual ou superior a 8\% e correspondem a $45 \%$ da população mundial. Áreas de elevada endemicidade compreendem a maior parte da Ásia (exceto Japão e Índia), e a maioria do Oriente Médio, a Bacia Amazônica na América do Sul, a maioria dos grupos das ilhas do Pacífico, a África, e algumas populações restritas como: os nativos do Alasca, os aborígines australianos e os Maoris da Nova Zelândia (MAHONEY, 1999).

Já nas áreas de endemicidade intermediária (10 a 60\% da população com contato prévio ao HBV), o risco de contágio durante a vida é de 20 a $60 \%$, e sua contaminação ocorre em todas as faixas etárias, tendo um misto de infecção perinatal, transmissão durante a infância - tipo padrão horizontal - e transmissão na fase adulta. Nestas áreas, a transmissão viral na infância precoce pode variar bastante nas mais diversas regiões e entre diferentes grupos étnicos de um mesmo país. A doença aguda tende a incidir em grupos de mesmo comportamento de risco, assim como nos países desenvolvidos. As áreas nesta situação de prevalência abrangem: o Brasil (fora a Amazônia), o norte da África, em parte da Ásia, o Leste europeu e parte da Europa Ocidental (ALTER, 2003a; MAHONEY, 1999).

As baixas taxas de prevalência ( 5 a $7 \%$ da população com contato prévio ao HBV e risco menor de $20 \%$ de infecção durante a vida) ocorrem nos países do primeiro mundo, e as infecções provêm de adultos com comportamentos de risco bem definidos: do uso de drogas ilícitas não injetáveis, de homens que fazem sexo com homens, de heterossexuais com múltiplos parceiros, de contactantes intradomiciliares de portadores crônicos do HBV, dos hemofílicos, dos pacientes em hemodiálise e dos profissionais de saúde e seus assistentes, dos presidiários de longas penas, das pessoas 
em exposição ocupacional a sangue e fluidos corporais, e de pessoas institucionalizadas com déficit da cognição (ALTER, 2003a; MAHONEY, 1999). Nestas regiões estão, além dos países ricos, parte das Américas do Sul e Central.

As estimativas apontam para o surgimento de pelo menos 140.000 casos por ano de hepatite B aguda na América Latina. Destes, 76.000 ocorrem no Brasil e 10.000 na Argentina (FAY, 1990). Região que apresenta característica bastante particular, a América Latina exibe os três padrões geográficos de transmissão do vírus da hepatite B. A prevalência do HBsAg nesta região varia de 0,5 a $3 \%$, com o total de portadores atingindo, aproximadamente, 11 milhões de pessoas. Conduto há uma área em especial que contém parte do Brasil central e ocidental e países adjacentes como Colômbia, Peru e Venezuela (Bacia Amazônica), que pode alcançar taxas acima de 8\% (CUSTER et al., 2004). Na América Latina, diversos fatores sócio-econômicos e culturais influenciam a variabilidade desta distribuição. O intenso fluxo migratório da população rural, se deslocando para centros urbanos a procura de melhores oportunidades, e a falta de recursos para campanhas preventivas influenciam a disseminação da doença (PARANÁ; ALMEIDA, 2005).

Relação sexual parece ser o principal mecanismo de transmissão do HBV na América Latina (TANAKA, 2000). A infecção perinatal não exerce um papel importante, exceto nas áreas com alta endemicidade como a Bacia Amazônica. Nesta região, elevadas prevalências ao vírus da hepatite $B$ são encontradas em populações indígenas (BLACK; PANDEY; CAPPER, 1986; COIMBRA et al., 1996; FERRARI et al., 1999) e estão associadas a práticas culturais peculiares como sangrias, escarificações, tatuagens, mastigação de alimentos para dar aos filhos e outras mais. Além disso, outro fator possível descrito na relação do HBV com os povos indígenas é a presença, nesta população, de reduzido nível de variabilidade genética, levando a uma maior predisposição para determinadas infecções (SANTOS et al., 1995).

Estudo de soroprevalência ao marcador anti-HBc mostrou taxas que variaram de $0,6 \%$ no Chile a $21,4 \%$ na República Dominicana (SILVEIRA et 
al., 1999). Leon et al. (1999) estudaram, na Bolívia, populações que apresentaram prevalências variando de 11,2 a 74\%. Já no México, VázquezMartínez et al. (2003) encontraram, em gestantes, prevalência de 1,65\%.

No Brasil, o número de casos de hepatite $\mathrm{B}$ é subestimado devido falha nas notificações da doença, apesar da melhora nos últimos anos. Segundo dados do Sistema de Informação de Agravos de Notificação (SINAN) (BRASIL, 2007a), a partir de 2001, o total de casos notificados de hepatite B acumula 13.679 indivíduos. Estes números vêm em elevação desde 2005, que exibiu 1.973 notificações, saltando para 10.802 casos notificados em 2006. Os dados destes dois últimos anos contabilizam mais de $90 \%$ de todas as notificações a partir de 2001. Talvez, isto deva corresponder muito mais ao maior registro dos casos do que, propriamente, a um incremento da infeç̧ão. Não há registros da taxa de portadores crônicos em nosso país.

O Brasil apresenta padrões geográficos de transmissão ao HBV de primeiro a terceiro mundo. Com alta prevalência, encontram-se a Amazônia, o Nordeste de Minas Gerais, algumas áreas do Espírito Santo e oeste de Santa Catarina; com prevalência intermediária aparecem as Regiões Nordeste, Centro-Oeste e Sudeste; e de menor prevalência, a Região Sul do país (BRASIL, 2004).

Diversos grupos étnicos nativos da Amazônia brasileira apresentam o HBsAg em taxas que podem ultrapassar $10 \%$ da população (AZEVEDO et al., 1996; FRANCO et al., 1985; GAYOTTO; QUARENTEl; CABRAL, 1984). Uma das grandes referências no mundo em relação à sua elevada endemicidade para hepatite B, a Amazônia Brasileira localiza suas altas taxas de prevalência, principalmente, nos vales dos rios Juruá, Purus e Madeira, na Amazônia Ocidental, e no vale do rio Tapajós, na Amazônia Oriental. As principais formas de contaminação nestes locais são a transmissão perinatal e, principalmente, o contato interpessoal por via sexual ou por contatos domiciliares (BENSABATH; LEÃO, 2003).

Focaccia et al. (1998) conduziram estudo sobre prevalência de hepatites virais no munić́pio de São Paulo, encontrando 5,94\% de 
contaminação com HBV, com 1,04\% em infecção ativa, e ausência de infecção na faixa etária abaixo dos 15 anos de idade, colocando esta cidade em patamar de baixa endemicidade.

\subsection{Hepatite C}

A hepatite $C$ é uma doença aguda ou crônica que acomete ao fígado, causada por um singular flavivirus hepatotrópicos: o vírus $C$ da hepatite (HCV). A partir do início da década de 1970, foi possível identificar, em especial, casos de hepatite que mostravam testes sorológicos - que começam a estar disponíveis à época - para hepatite $A$ e $B$ não reagentes. Denominada de hepatite não $A$ não $B$, a maioria destes casos estava associada à icterícia pós-transfusional (FEINSTONE et al., 1975; PRINCE et al., 1974). Em 1989, foi identificado o genoma do agente viral causador desta hepatite pós-transfusional, sendo então reconhecido o $\mathrm{HCV}$ ( $\mathrm{CHOO}$ et al., 1989). Este vírus apresenta particularidades que o distingue dos outros vírus hepatotrópicos (HOUGHTON et al., 1991). Em seguida à sua identificação, o desenvolvimento de um teste sorológico veio dar um grande passo na redução da incidência da infecção do $\mathrm{HCV}$, sobretudo nas transfusões de sangue e derivados (ALTER et al., 1989). Estima-se que esta primeira geração de testes diagnósticos por meio de ensaio imunoenzimático para o vírus da hepatite $C$ veio a prevenir, no primeiro ano de uso, por volta de 40.000 mil novas infecções (ALTER, 1999).

A contaminação pelo HCV ocorre essencialmente por exposição a sangue infectado, entretanto este contato não esclarece integralmente sua transmissão. Através de técnicas sensíveis, o HCV RNA pode ser detectado em fluidos corporais como saliva, líquido seminal, lágrima, líquor e líquido ascítico (LIOU et al., 1992; MENDEL et al., 1997). Transfusão sanguínea e de seus derivados era o principal modo de infecção antes da disponibilização da sorologia de hepatite $\mathrm{C}$ em bancos de sangue. Indivíduos com condições clínicas que favoreciam transfusões de sangue e derivados continuamente como hemofilia, insuficiência renal crônica, talassemia 
cirurgias cardíacas mostraram declínio no risco de contaminação pelo HCV por conta da introdução de métodos diagnósticos sorológicos. (BLAJCHMAN; BULL; FEINMAN, 1995; DONAHUE et al., 1992).

A população de UDI representa um enorme reservatório do HCV. O vírus parece ser adquirido rapidamente após o inicio da prática de injeção da droga em corrente sanguínea, mesmo em usuários eventuais (MATHEl; BUNTINX; VAN DAMME, 2002). Dentro de seis a doze meses após o início do uso de drogas ilícitas por via endovenosa, até $80 \%$ dos usuários tornamse soropositivos, tendo como fatores de risco: co-infecção com o Vírus da Imunodeficiência Humana (HIV) e/ou HBV e o tempo e a frequência de uso da droga (FOCACCIA; BARALDO; SOUZA, 2003). O uso de agulhas contaminadas em injeções de substâncias ilícitas pelos UDIs é a principal causa de contaminação pelo $\mathrm{HCV}$ em vários países desenvolvidos. Nos EUA, mais de $60 \%$ dos infectados pelo vírus da hepatite C são advindos do uso de drogas injetáveis com compartilhamento de agulhas e seringas (ALTER, 1997). Outro fator que parece estar associado à infecção pelo HCV em UDIs é a história prévia de encarceramento (CROFTS et al., 1993). A via injetável de drogas ilícitas não é a única com risco à contaminação de HCV. Conry-Cantilena et al. (1996) encontraram, em doadores de sangue com hepatite $\mathrm{C}$, forte associação da infecção com uso de drogas ilícitas por via inalatória intranasal.

Exposição a sangue ou fluidos corporais em acidente percutâneo ou permucoso pelos profissionais de saúde é um risco para infecção do HCV não desprezível. A taxa de soroconversão para anti-HCV - em alguns estudos - variou de 2,7 a 5,4\% (KIYOSAWA et al, 1991; MITSUI et al, 1992; SODEYAMA et al, 1993). O risco de contágio por acidente com agulha contendo sangue contaminado pelo HCV é estimado, de uma maneira geral, em $3 \%$, sendo cerca de dez vezes menor que com o HBV, e dez vezes maior em relação ao HIV (THOMAS; LEMON, 2000). Não obstante que a transmissão do HCV, mais freqüente, para os profissionais de saúde sejam nos acidentes pérfuro-cortantes, há relato de transmissão do $\mathrm{HCV}$ por respingos de sangue em mucosa de conjuntiva (SARTORI et al., 1993). Há 
risco de transmissão do HCV do profissional de saúde para paciente (ESTEBAN et al., 1996) e risco de paciente para paciente, como o relatado por Bronowicki et al. (1997), onde um indivíduo adquiriu HCV pelo uso de colonoscópio utilizado, imediatamente antes, em outro paciente infectado pelo vírus.

A transmissão perinatal do vírus da hepatite $\mathrm{C}$ é incomum, contudo é possível, com taxas de transmissão variando de 0 a 8,4\% (ROUDOTTHORAVAL et al., 1993; LAM et al., 1993; OHTO et al, 1994; THOMAS et al. 1998). Há correlação entre a viremia do HCV na mãe e a subseqüente infecção da criança. Além disso, uma hepatite $\mathrm{C}$ aguda durante a gravidez aumenta o risco de transmissão vertical do HCV para a criança (RESTI et al., 1998). A transmissão perinatal do HCV é facilitada nas mães coinfectadas com o HIV devido à elevação da carga viral do HCV determinada pela imunodeficiência (THOMAS et al., 1998). Não há consenso sobre a via e o momento da transmissão do HCV nos casos de transmissão perinatal. A detecção do HCV RNA na criança já ao nascer sugere que o momento da contaminação possa ocorrer ainda intra-útero. Ao mesmo tempo, Weiner et al. (1993) em estudo de biologia molecular apontam, também, transmissão no período perinatal. Embora o HCV RNA seja detectado no leite humano (OGASAWARA et al., 1993), não há evidências que sugiram risco de transmissão deste vírus para a criança por meio do aleitamento materno (ZANETTI; TANZI; NEWELL, 1999).

Embora a transmissão do HCV por via sexual seja infrequente, há estudos que mostram esta possibilidade (TEDDER et al., 1991; UTSUMI et al., 1995), reforçadas por pesquisas utilizando técnicas moleculares (HALFON et al., 2001; LU et al., 2007). Se esta ineficiência na transmissão sexual é devida a níveis baixos do vírus em fluidos genitais ou ausência de células alvos apropriadas no trato genital não se sabe (LAUER; WALKER, 2001). O HCV RNA pode ser detectado no sêmen e saliva (LIOU et al., 1992), o que pode favorecer à contaminação de indivíduos com início precoce da vida sexual e populações como profissionais do sexo. Indivíduos heterossexuais que freqüentam serviços de tratamento para DSTs, homens 
que fazem sexo com homens e parceiros sexuais de UDls têm soroprevalência maior do HCV (KEW et al., 2004; MEMON; MEMON, 2002). A transmissão do $\mathrm{HCV}$ entre casais é mais freqüente quanto maior for o tempo de convivência em comum (KAO et al., 1996), entretanto o uso compartilhado de utensílios de higiene pessoal pode dificultar a interpretação de dados que possam indicar a contaminação por via sexual entre casais (CAVAlHEIRO, 2004). Portadores do HCV co-infectados com HIV aparentam ter um maior risco de contaminação sexual (THOMAS et al., 1998).

Indivíduos em convivência domiciliar com portadores do $\mathrm{HCV}$ apresentam de 5 a 10 vezes maior positividade à sorologia anti-HCV comparados à população em geral. A maneira de transmissão do vírus da hepatite $\mathrm{C}$ em moradores do mesmo domicílio não é conhecida, todavia pode estar associada a compartilhamento de objetos de uso pessoal com a escova de dentes, lâminas de barbear e equipamento para cortar unhas (MEMON; MEMON, 2002).

Dados sobre outras vias de transmissão do HCV são mais especulativos. Outras vias têm sido propostas em alguns estudos e incluem: uso de cocaína intranasal, uso de piercing no corpo, tatuagem, tratamento com acupuntura, barbear em barbearias comunitárias, salões de beleza com uso compartilhado de equipamento para cortar unhas. (HENDERSON, 2003).

\subsubsection{Prevalência do vírus da hepatite $\mathrm{C}$}

Segundo a Organização Mundial da Saúde (OMS), há uma estimativa de 170 milhões de indivíduos infectados pelo $\mathrm{HCV}$ no mundo, o que corresponde a quase 3\% da população do planeta (WHO, 1999). Estes dados se baseiam, em grande parte, em estudos realizados com base em grupos populacionais, especialmente, em doadores de sangue.

De acordo com Wasley e Alter (2000), os poucos trabalhos com grupos de populações específicas demonstram, pelo menos, três perfis epidemiológicos distintos de transmissão do HCV pelo mundo. 
No primeiro padrão, a prevalência do HCV é baixa nos jovens menores de 20 anos e aumenta nos adultos de 30 a 49, diminuindo intensamente nos acima de 50 anos. Este padrão é encontrado nos EUA e Austrália. Prevalência baixa em crianças e adultos é encontrada no segundo padrão geográfico. Neste, a prevalência se eleva fortemente nas pessoas mais velhas. Este comportamento é visto no Japão e na Itália, onde há uma indicação de que o risco de infecção do HCV foi maior em um período de 30 a 50 anos atrás. Aumentando continuamente com a idade, o terceiro e último padrão mostra elevadas taxas de infecção do vírus da hepatite $\mathrm{C}$ em todos os grupos etários. Um representante deste perfil é o Egito, que apresenta risco de contaminação em passado distante e que se manteve nos períodos subseqüentes.

Injeções não seguras, aplicadas em serviços de saúde dos países em desenvolvimento, contribuem de forma extraordinária na disseminação do $\mathrm{HCV}$. Materiais de injeções contaminados mostram-se como o principal fator de risco de contaminação em diversos países, incluindo vários dos mais populosos no mundo (SHEPARD; FINELLI; ALTER, 2005). Como exemplo, o Egito apresenta prevalência que varia de 10 a 30\%, fazendo com que este país seja o de mais elevada soroprevalência em todo planeta. Este demasiado grau de infecção é imputado ao uso de seringas de vidro contaminadas nas campanhas de tratamento de esquistossomose (FRANK et al., 2000). Estimativas apontam que os usos de injeções não seguras geraram dois milhões de novas infecções pelo HCV no ano de 2000 (HAURI; ARMSTRONG; HUTIN, 2004).

Segundo dados do SINAN (BRASIL, 2007a), 15.276 casos confirmados de hepatite C foram notificados de 2001 a 2006 no Brasil. Até 2004, o número de casos notificados estava em três dígitos, todavia triplicou de 2005 para 3.150, e saltou para 9.917 no ano seguinte. Como na hepatite $B$, este aumento de casos pode ser devido ao aperfeiçoamento nas notificações. Em quase metade destes casos (47,8\%), a fonte de infecção foi ignorada. Entre as fontes identificadas, a transfusão de sangue e derivados 
$(15,1 \%)$ foi a mais comum seguido pelo, uso de drogas injetáveis $(14,3 \%)$ e pelo tratamento cirúrgico/dentário (5,6\%).

Não há dados precisos sobre a prevalência da hepatite C no Brasil. Taxa de 1,42\% foi encontrada em estudo de prevalência geral de Focaccia et al (1998), em 1059 indivíduos do Município de São Paulo. Em inquérito realizado pela Sociedade Brasileira de Hepatologia (Fonseca, 1999), foram analisadas sorologias para hepatite $\mathrm{C}$ em algumas populações específicas como: doadores de sangue, doentes hematológicos e pacientes hemodializados. Nos primeiros, foram encontrados valores que variam de 0,65, na Região Sul a 2,12\% na Norte. Como exemplo para pacientes hematológicos, os hemofílicos apresentaram soropositividade ao HCV de $51,57 \%$. Já em indivíduos submetidos à diálise de rotina, encontraram-se números bem mais elevados por região, variando de 23,8 na Nordeste até 45,5 na Norte.

\subsection{O sistema carcerário e as hepatites B e C}

No Brasil, segundo o Ministério da Justiça, existiam 419.551 presidiários até junho de 2007 , dos quais quase $95 \%$ pertencentes ao sexo masculino (BRASIL, 2007b). Estão distribuídos em estabelecimentos prisionais como penitenciárias, cadeias públicas, colônias agrícolas e outros, que não são suficientes para atender a demanda de presos. O sistema prisional do Estado de São Paulo, em dezembro de 2006, abrigava 144.430 indivíduos, mais de 30\% de todos os presos do Brasil (SÃO PAULO, 2006).

No Estado de São Paulo, a cidade de Ribeirão Preto conta com duas unidades prisionais, para indivíduos com penas já estabelecidas, que são a Penitenciária de Ribeirão Preto e a Cadeia Pública de Vila Branca, hoje transformada em presídio feminino. Além destas, há o Centro de Detenção Provisória (CDP), que abriga detentos à espera de julgamento. $\mathrm{O}$ total de encarcerados nestas prisões está por volta de 2000 pessoas.

A população prisional é considerada de alto risco para infecções relacionadas às condições de confinamento, como: HIV, hepatite $B$, hepatite 
C e DSTs em geral. Fatores de risco como marginalização, dependência de drogas ilícitas, baixo nível socioeconômico e precárias condições do sistema de saúde de nosso país são fatores facilitadores da alta disseminação destas doenças (MASSAD, 1997). Muitos destes indivíduos, freqüentemente, praticam sexo sem uso de preservativos em práticas homossexuais, compartilham seringas quando usam drogas ilícitas por via endovenosa ou tatuam suas peles sem boas condições de higiene.

Evidência de infecção pelo HBV em aprisionados já remonta desde II Guerra Mundial, quando soldados australianos, presos no Japão, tiveram seus sangues testados para marcadores da hepatite B quarenta anos após (SMITH et al., 1987). Já no final da década de 1960, a presença da hepatite B entre presidiários foi estudada por Hok et al. (1970) que comparou, neste grupo, a relação entre positividade do antígeno Austrália com a elevação da aspartato aminotransferase (AST). A partir do início da década de 1970, alguns estudos começaram a observar que a presença do HBsAg em população carcerária era maior que na população em geral, com taxas que variavam de 1,5 a 2,1\% (KLIMAN, 1971; KROTOSKI, 1972; MUÑIZ; MALAYSKA; LEVIN, 1971;). Àquela época, os presos eram usados para doação de sangue e derivados. Com o surgimento de surtos de hepatite em pacientes receptores destes sangues e a comprovação de que os presidiários apresentavam mais frequentemente hepatite B, Krotoski et al. (1972) levantaram a discussão sobre a restrição do uso deste sangue e implementação de testes rotineiros para a detecção de HBsAg para todo doador deste grupo populacional. Com a melhora da qualidade dos testes dos testes laboratoriais, números mais elevados de prevalência da infecção pelo HBV foram relatados. Ainda na década de 1970, Koplan, Walker e Bryan (1978) encontraram taxas de $8 \%$ para HBsAg e 33,2\% para anticorpo contra o antígeno de superfície (anti-HBsAg), sugerindo que a presença desse vírus nos presidiários era maior do que se pensava. No início da década de 1980, já era praticamente consensual entre os autores a maior prevalência para a infecção do HBV nas prisões e seu amplo risco de disseminação, considerando a possibilidade da vacinação dos reclusos 
como política de saúde pública (BADER, 1983; KIBBY; DEVINE; LOVE, 1982). Com a disponibilidade de testes para a detecção do anticorpo contra antígeno do núcleo (anti-HBc), que indica infecção natural pelo HBV, foi constatada prevalência mais elevada para este vírus nos encarcerados, independente de ser portador do HBsAg. Dessa forma, ainda nos anos de 1980, pesquisas realizadas em prisões norte americanas confirmaram altas taxas de infectados pelo vírus da hepatite B, que variavam de 19 a 47\% (ANDA et al., 1985; DECKER et al., 1984; HULL et al., 1985).

Em vários países do mundo a situação do HBV no sistema carcerário também é motivo de estudo. Na Inglaterra foi encontrada uma prevalência para o anti-HBc de 8\% (WEILD et al., 2000). Na Itália, a presença do HBsAg em estudo realizado na prisão, em 1982, era de 6,7\% (CHIARAMONTE et al., 1982). Na cidade de Marselha, na França, 32\% dos presidiários apresentou marcador para HBV presente (ROTILY et al., 1997). Em prisões espanholas, a taxa de positividade para anti-HBc era de 54\% (ACEDO et al., 1989). No continente africano, Gana apresentou índice de $17,4 \%$ presos com exame reagente ao HBsAg (ADJEl et al., 2006). Na Austrália, Butler et al. (1997) fizeram pesquisa de hepatite $B$ e hepatite $C$ na penitenciária de New South Wales e encontram forte associação da presença dessas infecções com uso de drogas ilícitas injetáveis. A soroprevalência para anti$\mathrm{HBc}$ foi de $31 \%$.

Em nosso país, há poucos estudos sobre a questão, além de terem sido realizados há mais de dez anos. A maior parte destes estudos investigou-se apenas a presença do HBsAg, muitas vezes de forma isolada, sendo descrita prevalência deste antígeno de 26,4\% em Goiânia-GO (MARTELLI et al., 1990); 1,89\% na cadeia pública de Londrina-PR; (JABUR; BALDY; QUESADA, 1991); 17,5\% na cadeia mineira de Manhuaçu (CATALAN-SOARES; ALMEIDA; PROIETTI, 2000). Em duas cadeias paulistas, Veronesi et al. (1993) encontraram $6,5 \%$ e $48,8 \%$, respectivamente. Em pesquisa mais recente, avaliação do anti-HBc em adolescentes infratores da Fundação CASA (Centro de Atendimento Sócio- 
Educativo ao Adolescente), antiga FEBEM, encontrou-se taxa de $16 \%$ (CARVALHO et al., 2003).

Em relação ao $\mathrm{HCV}$, os números apontam para valores mais elevados do que o HBV. Reindollar (1999) afirma que a alta prevalência da hepatite $\mathrm{C}$ no sistema correcional é resultante de um ciclo bem definido, formado de indivíduos provenientes de ambiente de alto risco, com comportamento de risco dentro das prisões. Como exemplo, Tsang, Horowitz e Vugia, (2001) relataram caso de um preso na Califórnia que apresentou hepatite C aguda, sendo seu único fator de risco para a doença uma tatuagem feita em sua cela menos de dois meses antes. Nos EUA, a evidência sorológica para hepatite C nas prisões é estimada entre 15 a 30\%, indicando taxa maior que 20 vezes que na população em geral (BOUTWELL; ALLEN; RICH, 2005).

Em outros países, a prevalência para presidiários infectados com hepatite C também é elevada. Na Inglaterra, encontrou-se valor de 7\% (WEILD et al., 2000). Já na Nova Zelândia, estudo englobando penitenciárias femininas e masculinas resultou em uma prevalência de $39 \%$ para infecção pelo HCV (BUTLER et al., 1999). Na Noruega (HOLSEN, 1993) e em Gana (ADJEl et al., 2006) 46\% e 19,2\% de sorologia reagente, respectivamente.

Quase não há dados sobre infecção da hepatite $C$ em prisões brasileiras. Para ilustrar, destaca-se pesquisa nos anos de 1993 e 1994 na Casa de Detenção em São Paulo revelou 41\% de indivíduos com anti-HCV positivo (GUIMARÃES, 2001).

A disseminação de doenças infecciosas nas prisões é uma preocupação real de todo profissional de saúde da área preventiva. A situação de confinamento, nos moldes do nosso atual sistema carcerário, constitui uma condição sanitária de difícil controle, uma vez que atinge milhares de pessoas que entram para cumprir pena e retornam à sociedade de forma contínua, além das que trabalham nestas instituições e as que as visitam. 
As altas taxas de infecção com HIV e HCV entre os encarcerados, comparado com a população em geral, indicam que programas de prevenção devem ser instituídos com base no conhecimento da situação de transmissão nesses locais. Por isso, mais informações sobre a real situação de prevalência de nossas penitenciárias são necessárias para se traçar metas de ação, visando a prevenção e assistência, evitando que estes presos possam atuar como fontes transmissoras do HBV, HCV e HIV para outros presos e para as parceiras sexuais durante a visita íntima.

No Brasil, a epidemia de aids e, especialmente, a hepatite $C$ na população prisional não estão sendo tratadas da forma mais adequada há vários anos. A falta de definições centralizadas para a abordagem deste problema enfatiza a necessidade de realização de estudos de abrangência nacional que permitam a elaboração de estratégias eficazes para seu controle. Portanto, torna-se urgente uma penetração, ainda maior do que já existe, em todo sistema prisional brasileiro, para levar adiante um programa de assistência e prevenção de qualidade. 


\section{OBJETIVOS}

$\mathrm{Na}$ população carcerária masculina da Penitenciária de Ribeirão Preto, SP, este estudo objetivou:

1. Estimar a prevalência de infecção pelo HBV.

2. Investigar os fatores de riscos associados à infecção pelo HBV.

3. Estimar a prevalência de infecção pelo HCV.

4. Investigar os fatores de riscos associados à infecção pelo HCV. 
3 POPULAÇÃO, MATERIAL E MÉTODOS

\subsection{Modelo de Estudo}

Este estudo foi realizado utilizando-se o modelo transversal.

\subsection{Divisão da População Carcerária}

A penitenciária de Ribeirão Preto divide seus 1.030 presidiários (número de maio de 2003) em basicamente três ambientes:

A. Pavilhões. São em número de quatro e abrigam mais de $80 \%$ dos presos em regime fechado, assim distribuídos:

\begin{tabular}{ll} 
Pavilhão I & 189 presos. \\
Pavilhão II & 234 presos. \\
Pavilhão III & 236 presos \\
Pavilhão IV & 234 presos \\
\cline { 2 - 2 } Total & 893 presos
\end{tabular}

B. "Seguro". Ala dos presos que correm risco de morte e necessitam de isolamento. Contava com 30 presos.

C. Ala de progressão continuada (APP). Área que contém os presos que saem do regime fechado dos pavilhões para o semiaberto. Existiam 107 presos. 


\subsection{População de Referência}

A população de referência foi representada pela totalidade dos 893 presidiários confinados em regime de prisão fechada nos 4 pavilhões da Penitenciária Ribeirão Preto, excluídos os 137 detentos do "Seguro" e da APP, no início do estudo, em maio de 2003.

\subsection{População de Estudo e Tamanho Amostral}

A partir da população de referência foi realizada uma amostragem de indivíduos baseando-se na prevalência para infecção do HBV em presídios, com base na fórmula utilizada para determinação do $n$ em levantamentos:

$$
n=\frac{Z^{2} P Q}{d^{2}}
$$

onde:

$\mathrm{n}=$ tamanho amostral mínimo;

$Z$ = variável reduzida, cujo valor para um alfa de 0,05 é 1,96;

$\mathrm{P}=$ prevalência estimada de se encontrar o fenômeno estudado;

$\mathrm{Q}=$ complemento da prevalência estimada $(1-\mathrm{P})$;

$\mathrm{d}$ = precisão desejada, ou seja, a diferença admitida entre a verdadeira prevalência e a prevalência estimada pela pesquisa.

De acordo com estudos anteriores em outras penitenciárias brasileiras, o P foi definido baseado na estimativa de prevalência da infecção pelo HBV da ordem de 20,0\%. Para a precisão desejada (d), visando uma compatibilização com os recursos disponíveis, empregou-se o valor de 5 .

Assim sendo, assumindo um alfa de 0,05, uma precisão (d) de 5 e uma prevalência estimada de infecção pelo HBV da ordem de 20,0\%, o tamanho amostral mínimo determinado foi de 245 indivíduos. Ao final, participaram do estudo 333 indivíduos, que constituíram a amostra de 
estudo.

Empregando-se um processo de amostragem casual simples, foram sorteados 100 presos de cada um dos quatro pavilhões. Destes 400, concordaram em participar do estudo 333 presos, no período de 13 de maio a 14 de agosto de 2003, assim distribuídos:

\begin{tabular}{ll} 
Pavilhão I & 87 presos \\
Pavilhão II & 83 presos \\
Pavilhão III & 86 presos \\
Pavilhão IV & 77 presos \\
\cline { 2 - 2 } Total & 333 presos
\end{tabular}

\subsection{Critérios de Inclusão}

Foram incluídos todos os presidiários sorteados que manifestaram concordância em participar da pesquisa mediante assinatura do termo de consentimento livre, após tomar conhecimento dos seus objetivos e metodologia (Apêndice 1).

\subsection{Critérios de Exclusão}

Foram inicialmente excluídos os presos do "seguro" - por questão de segurança dos próprios - e os da APP, por serem de alta rotatividade e se alojarem em área de difícil acesso ao local da realização do estudo. Dos presos sorteados, foram excluídos apenas os que se recusaram a participar do estudo, após tomar conhecimento dos seus objetivos e metodologia, em número de 67.

\subsection{Localização da Penitenciária e Local do Estudo}

O presente estudo foi realizado na Penitenciária de Ribeirão Preto, situado na Rodovia Abrão Assed (SP-333), KM 47, em Ribeirão Preto-SP. Esta unidade prisional conta com ala para cuidados em saúde Nesta área há 
duas salas de ambulatório para atendimento médico, uma sala devidamente equipada para atendimento odontológico, um posto de coleta de exames laboratoriais e um posto de enfermagem, com salas para administrar medicamentos e para realização de curativos. O local conta ainda com oito celas individuais para presos que necessitem isolamento por motivo de ordem médica.

\subsection{Coleta de Informações}

Foram fornecidas a todos os presos contatados, em linguagem acessível, informações sobre aids, hepatites B e C e outras DSTs: principais aspectos de transmissão e evolução, riscos associados a diferentes práticas sexuais e importância do diagnóstico sorológico. Àqueles que concordaram em participar, solicitou-se leitura do termo de consentimento (Apêndice 1), seguido de assinatura. Em seguida o participante foi submetido à aplicação de questionário específico (Apêndice 2), através de entrevista realizada pelo próprio pesquisador, garantindo-se sigilo absoluto de todas as informações coletadas, bem como dos resultados sorológicos, acordado em termo de consentimento (Apêndice 1). Cada entrevista para preenchimento do questionário durava cerca de 10 a 15 minutos e era realizada na dependência destinada à aplicação de medicamentos.

\subsection{Variáveis Coletadas Através do Questionário}

Foram estudadas 38 variáveis, a seguir discriminadas:

3.9.1 Nome: identificação verdadeira do participante, idêntica à lista fornecida pela administração da penitenciária.

3.9.2 Nascimento e idade: dia, mês e ano do nascimento e idade completa. 
3.9.3 Estado civil: codificado como:

1. casado

2. solteiro

3. amasiado

4. viúvo

5. divorciado/separado

3.9.4 Filhos: número total de filhos do participante

3.9.5 Local de nascimento: codificado como:

1. Ribeirão Preto

2. região de Ribeirão Preto

3. outra região do Estado de São Paulo

4. outro estado.

3.9.6 Local de residência: anotado de modo análogo ao item 3.9.5.

3.9.7 Escolaridade: tempo de estudo do participante, assim codificado:

1. nenhuma

2. até 2 anos

3. 2 a 5 anos

4. 5 a 8 anos

5. colegial incompleto

6. colegial completo

7. superior incompleto

8. superior completo.

3.9.8 Tempo total da pena: período total do encarceramento do participante.

3.9.9 Tempo já cumprido: tempo contado a partir da prisão do participante até o momento do estudo.

3.9.10 Internação em reformatório/FEBEM: internação em instituições corretivas quando o participante era menor de idade, assim codificado:

1. sim

2. não

3. não sabe 
3.9.11 Antecedentes de doenças sexualmente transmissíveis (DSTs) do tipo ulcerativa: qualquer episódio de uma ou mais DSTs com úlcera, assim codificado:
1. não
2. uma vez
3. mais de uma vez

3.9.12 Tratamento das DSTs do tipo ulcerativa: se houve por parte do participante tratamento das DSTs do tipo ulcerativa, e onde tratou, de acordo com as opções:
1. médico
2. não tratou
3. não se aplica
4. farmácia

3.9.13 Antecedentes de DSTs do tipo não ulcerativa: qualquer episódio de uma ou mais DST sem úlcera, seguindo as opções:
1. não
2. uma vez
3. mais de uma vez.

3.9.14 Tratamento das DSTs do tipo não ulcerativa: se houve por parte do participante tratamento das DSTs do tipo ulcerativa, e onde tratou, de acordo com as opções:
1. médico
2. não tratou
3. não se aplica
4. farmácia

3.9.15 Circuncisão: o participante já realizou cirurgia de postectomia, apresentando as opções:
1. sim
2. não

3.9.16 Tatuagem: o participante tinha realizado e/ou apresentava tatuagem. As respostas classificadas em:

1. $\operatorname{sim}$

2. não

3.9.17 Piercing: o participante realizou e/ou apresentava piercing. As respostas foram classificadas como:

$\begin{array}{ll}\text { 1. } & \text { sim } \\ \text { 2. não }\end{array}$ 
3.9.18 Sorologia para HIV previamente: o participante já realizou exame para HIV e quantas vezes. As opções de resposta foram classificadas em:
1. não
2. uma vez
3. mais de uma vez
4. não sabe

3.9.19 Resultado da sorologia para HIV previamente: se o participante realizou sorologia para HIV previamente, qual seu resultado. As respostas foram classificadas como:
1. positivo
2. negativo
3. não sabe
4. não se aplica

3.9.20 Transfusão: se o participante tinha recebido transfusão de sangue. As respostas foram classificadas em:
1. não
2. uma vez
3. mais de uma vez
4. não sabe

3.9.21 Relacionamento sexual com usuários de drogas ilícitas: o participante teve relação sexual com alguma pessoa que tivesse usado algum tipo de droga ilícita. As respostas foram definidas como:
1. sim
2. não

3.9.22 Uso de drogas ilícitas não injetáveis agora ou no passado: consumo atual ou passado de drogas ilícitas não injetáveis; se a resposta fosse afirmativa, especificar nome (s). As respostas foram classificadas em:
1. sim
2. não
3. não sabe

3.9.23 Uso de drogas ilícitas injetáveis no passado: consumo no passado de drogas ilícitas injetáveis, classificado em:
1. freqüentemente
2. às vezes
3. raramente
4. uma vez
5. nunca
6. não se aplica 
3.9.24 Tempo de uso de drogas ilícitas injetáveis no passado: se o participante fez uso de drogas injetáveis por quanto tempo. As opções foram:

1. mais de 5 anos

2. 3 a 5 anos

3. 1 a 3 anos

4. menos de um ano

5. não se aplica.

3.9.25 Compartilhamento no passado de agulhas ou seringas: uso compartilhado de agulhas e/ou seringas para injetar drogas ilícitas no passado. As opções foram classificadas como:

1. freqüentemente

2. às vezes

3. raramente

4. uma vez

5. nunca

6. não se aplica

3.9.26 Uso atual de drogas ilícitas injetáveis: consumo atual de drogas ilícitas injetáveis, assim codificadas:

1. freqüentemente

2. às vezes

3. raramente

4. uma vez

5. nunca

6. não se aplica.

3.9.27 Compartilhamento atual de agulhas ou seringas: uso compartilhado de agulhas e/ou seringas para injetar drogas ilícitas atualmente. As opções foram classificadas como:

1. freqüentemente

2. às vezes

3. raramente

4. uma vez

5. nunca

6. não se aplica

3.9.28 Preferência sexual: o participante tem preferência por algum tipo de sexo abaixo relacionado. As respostas foram classificadas em:

1. heterossexual

2. homossexual

3. bissexual

4. desconhecido 
3.9.29 Quantos parceiros teve um ano antes da prisão: número de parceiros com quem o participante teve relação sexual um ano antes da prisão.

3.9.30 Visita íntima: se o participante tem visita íntima com parceiro (a). As opções foram assim codificadas:

1. sim

2. não

3.9.31 Uso de preservativo na visita íntima: freqüência de uso de preservativo, pelo participante nas relações sexuais da visita íntima, classificada em:
1. sempre
2. às vezes;
3. nunca
4. não se aplica

3.9.32 Sexo com colegas na prisão: se o participante tem relações sexuais com colegas da prisão. As respostas foram codificadas em:

1. freqüentemente

2. às vezes

3. raramente

4. uma vez

5. nunca

6. não sabe

3.9.33 Forma de sexo com os colegas: Tipo de sexo praticado entre o participante e colegas de prisão, classificado da seguinte maneira:
1. ativo
2. passivo
3. ativo/passivo
4. só oral
5. só masturbação
6. não se aplica

3.9.34 Uso de preservativo em relação sexual com os colegas: freqüência de uso de preservativo nas relações sexuais com colegas de prisão, classificada em:
1. sempre
2. às vezes
3. nunca
4. não se aplica 
3.9.35 Antecedentes de icterícia: se o participante apresentou no passado evidências de icterícia. As respostas foram classificadas em:

1. $\operatorname{sim}$

2. não

3. não sabe

3.9.36 Antecedentes de hepatite: se o participante apresentou no passado manifestações clínicas de hepatite, segundo ele próprio. As respostas foram classificadas em:

1. sim

2. não

3. não sabe

3.9.37 Tabagismo: se o participante fuma cigarros atualmente. As respostas foram classificadas em:

1. sim

2. não

3. não sabe

\subsection{Coleta de Sangue}

Para a coleta de sangue, foram utilizadas agulhas descartáveis e dois tubos do tipo vacutainer, sendo um com capacidade de $5 \mathrm{ml}$, para sorologias do HIV e sífilis, e outro de $10 \mathrm{ml}$, para sorologias de hepatite B e C. Cada tubo foi identificado com as iniciais dos nomes e com o número de ordem do questionário aplicado. As amostras foram coletadas, na grande maioria, na semana seguinte à aplicação do questionário. O sangue foi colhido por auxiliar de enfermagem, funcionária concursada da penitenciária e, posteriormente, por enfermeira graduada designada para esse fim pelo pesquisador. Todo material de consumo utilizado para obtenção destas amostras foi adquirido pelo Programa de DSTIAIDS da Secretaria de Saúde de Ribeirão Preto.

Após a coleta, as amostras foram armazenadas em caixa de isopor, dentro da qual havia estantes de madeira projetadas especialmente para permitir que os tubos permanecessem em uma inclinação de aproximadamente $15^{\circ}$, para facilitar a retração do coágulo e possibilitar melhor rendimento do soro de cada amostra. $O$ isopor foi mantido 
refrigerado com barras de gelo reciclável, colocadas entre as estantes, o que manteve a temperatura $\mathrm{a}-10^{\circ} \mathrm{C}$ por 3 horas.

Terminada a coleta, as amostras eram encaminhadas, pelo próprio pesquisador, ao laboratório de referência de sorologias para DSTs da Secretaria de Saúde de Ribeirão Preto, no posto de saúde do Castelo Branco, onde eram deixados os tubos com sangue para a realização das sorologias do HIV e sífilis. O restante era conduzido ao Hospital das Clínicas da Faculdade de Medicina de Ribeirão Preto da Universidade de São Paulo (HCFMRP-USP), onde foram centrifugados e estocados a $-20^{\circ} \mathrm{C}$ e, posteriormente, enviados ao Centro de Referência Nacional de Hepatites Virais do Instituto Oswaldo Cruz (FIOCRUZ). A estocagem não excedeu oito meses.

\subsection{Análise Sorológica}

Inicialmente, os exames para hepatite B e C foram realizados no Centro de Referência Nacional de Hepatites Virais do Instituto Oswaldo Cruz (FIOCRUZ). Para hepatite B, foram feitos testes para três marcadores: antígeno de superfície ( $\mathrm{HBsAg}$ ), anticorpo contra antígeno de superfície (anti-HBsAg) e anticorpo contra core (anti-HBc total). Para hepatite C realizou-se a sorologia anti-HCV. As amostras positivas para hepatite $\mathrm{C}$ foram submetidas a novo teste sorológico e de reação de polimerase em cadeia no Laboratório de Sorologia e Laboratório de Gastroenterologia, respectivamente, do Hospital das Clínicas da Faculdade de Medicina de Ribeirão Preto da USP.

\subsection{Descrição dos Métodos Sorológicos}

Serão descritos os métodos imunoenzimáticos para HBsAg, anti-HBc total, anti-HBs e anti-HCV; o método imunocromatográfico para anti-HCV e a pesquisa do RNA HCV. 


\subsubsection{Métodos imunoenzimáticos}

\section{- HBsAg:}

Produzido pelo fabricante Biokit, o Bioelisa HBsAg é um teste imunoenzimático direto, do tipo "sanduíche", para detecção qualitativa do antígeno de superfície do vírus da Hepatite B (HBsAg) em amostras de soro e plasma humano. Os controles e as amostras são adicionados à microplaca, previamente sensibilizada com anticorpos anti-HBs (cobaia). Após incubação o antígeno HBsAg, se presente, se ligará aos anticorpos anti-HBs ocorrendo a reação antígeno-anticorpo. Após lavagem para a remoção de material não ligado e outros componentes séricos, adiciona-se o conjugado (anticorpo anti-HBs de cabra conjugado à peroxidase). Ao longo da incubação, os anticorpos marcados presentes no conjugado ligam-se ao HBsAg capturado na fase sólida. Após nova lavagem, é adicionada uma solução de substrato/cromógeno. A reação enzima-substrato produz uma coloração azul, proporcional à quantidade de HBsAg presente na amostra. Esta última reação é concluída pela adição de ácido sulfúrico $1 \mathrm{~N}$ e a intensidade da cor amarela será medida por leitura espectrofotométrica a $450 \pm 2 \mathrm{~nm}$, com comprimento de onda de referência na faixa de $620 \mathrm{~nm}$. Todas as amostras com resultados inicialmente reativos foram retestadas em duplicata. O resultado final foi considerado reagente se, ao menos, duas das três replicatas apresentarem reatividade para o marcador.

\section{- anti-HBc total:}

O Hepanostika anti-HBc UNI-FORM, da Biomerieux, é um teste imunoenzimático (ELISA) para a detecção qualitativa de anticorpos totais contra o antígeno core do vírus da hepatite B (Anti-HBc total) em amostras de soro ou plasma, baseado num princípio único de inibição competitiva. Após o término do ensaio, o desenvolvimento de cor sugere a ausência de anti-HBc, enquanto que o não aparecimento de cor ou apenas 0 aparecimento de uma coloração leve sugere a presença de anti-HBc. A 
microplaca é revestida com antígeno core. $\mathrm{O}$ anticorpo anti-HBc conjugado com peroxidase é utilizado como conjugado. As amostras e os controles são incubados juntamente com o conjugado. Quando a amostra não contém anti$\mathrm{HBc}$, forma-se um complexo entre o anticorpo marcado e o antígeno imobilizado na fase sólida. Após a lavagem e a incubação com o substrato tetrametilbenzidina (TMB), a ação da enzima sobre o TMB ocasionará o desenvolvimento de coloração azul. A adição da solução de parada produzirá uma coloração amarela. Todas as amostras com resultados inicialmente reativos foram retestadas em duplicata. $O$ resultado final foi considerado reagente se, ao menos, duas das três replicatas apresentarem reatividade para o marcador.

\section{- anti-HBs:}

O Bioelisa anti-HBs, produzido pelo Biokit, é um teste imunoenzimático, do tipo "sanduíche" para detecção qualitativa de anticorpos anti-HBs em amostras de soro. Os controles e as amostras são adicionados à microplaca, previamente sensibilizada com HBsAg. Após a incubação, os anticorpos anti-HBs, se presentes, se ligam ao antígeno HBsAg. Após a lavagem para a remoção de material não ligado e outros componentes séricos, adiciona-se o conjugado (HBsAg humano conjugado à peroxidase). Durante a incubação, o antígeno HBsAg marcado se liga ao complexo antígeno-anticorpo capturado na fase sólida. Após a lavagem e incubação com o substrato/cromógeno há a formação de cor azul decorrente da reação enzima-sustrato, na presença de anti-HBs. Esta última reação é concluída pela adição de ácido sulfúrico $1 \mathrm{~N}$ e a intensidade da cor amarela será medida por leitura espectrofotométrica a $450 \pm 2 \mathrm{~nm}$, com comprimento de onda de referência na faixa de $620 \mathrm{~nm}$. Todas as amostras com resultados inicialmente reativos foram retestadas em duplicata. $\mathrm{O}$ resultado final foi considerado reagente se, ao menos, duas das três replicatas apresentarem reatividade para o marcador. 
O Bioelisa HCV é um teste imunoenzimático fabricado pela Biokit para detecção qualitativa de anticorpos anti-HCV em amostras de soro ou plasma. O teste emprega antígenos recombinantes, correspondentes às regiões de capsídeo (core), NS3, NS4 e NS5 do vírus. Os controles e as amostras são adicionados à microplaca, previamente sensibilizada com os antígenos. Se anticorpos anti-HCV estiverem presentes na amostra, após a incubação, ocorrerá a reação antígeno-anticorpo. A próxima etapa consiste na lavagem da microplaca, de modo a remover anticorpos não ligados e outros componentes séricos. Na segunda fase do teste, acrescenta-se o conjugado (anticorpo de coelho anti-IgG humano, conjugado à enzima peroxidase). Ao longo da incubação, os anticorpos marcados presentes no conjugado ligam-se aos anticorpos capturados na fase sólida. Após nova lavagem, onde o material não ligado é removido, adiciona-se uma solução de substrato/cromógeno. A reação enzima-substrato produz uma coloração azul, proporcional à quantidade de anticorpos anti-HCV presentes na amostra. Esta última reação é concluída pela adição de ácido sulfúrico $1 \mathrm{~N}$ e a intensidade da cor amarela será medida por leitura espectrofotométrica a $450 \pm 2 \mathrm{~nm}$, com comprimento de onda de referência na faixa de $620 \mathrm{~nm}$. Todas as amostras com resultados inicialmente reativos foram retestadas em duplicata. O resultado final foi considerado reagente se, ao menos, duas das três replicatas apresentarem reatividade para o marcador.

\subsubsection{Método imunocromatográfico}

\section{- anti-HCV}

O teste imunocromatográfico é feito por kit comercial HCV Rapid Test Bioeasy, Bioeasy Diagnóstica, Belo Horizonte, MG, Brasil, empregando proteínas NS3 NS4 e NS5 do HCV, desenvolvido e analisado de acordo com as especificações do fabricante. 


\subsubsection{Método de reação de polimerase em cadeia}

\section{- RNA HCV}

Pesquisa do RNA HCV: feita por método qualitativo, com limite de detecção e $50 \mathrm{UI} / \mathrm{ml}$, empregando o teste AMPLICOR ${ }^{\circledR}$ (Hepatitis C virus (HCV) test), version 2, Roche Molecular Systems Inc., Branchburg, NJ, USA, desenvolvido e analisado de acordo com as especificações do fabricante.

\subsection{Digitação e Organização dos Dados}

Os dados da pesquisa foram digitados pelo próprio autor, criando-se um banco de dados no Programa EPIINFO 6.04 (EPIINFO, 1994), que posteriormente foram transferidos para o Programa STATA 6.0. (STATA, 1999).

\subsection{Análise Estatística}

As possíveis associações entre as variáveis qualitativas ou quantitativas estratificadas e as presenças dos marcadores para o HBV e HCV foram testadas inicialmente através de uma análise univariada pelo teste do $\chi^{2}$. Nas ocasiões em que o teste não pode ser aplicado, em razão do reduzido número de participantes, optou-se pelo teste exato de Fischer. Estas análises foram realizadas através do pacote STATA na sua versão 6.0 (STATA, 1999). As variáveis que na análise univariada apresentaram um valor de "p" igual ou inferior a 0,25 foram selecionadas para uma análise multivariada, através de um modelo de regressão logística (HOSMER; LEMESHOW, 2000).

\subsection{Aspectos Éticos}

O presente projeto foi aprovado pelo Comitê de Ética e Pesquisa do HCFMRP-USP, em sua $152^{a}$ Reunião Ordinária realizada em 28/04/2003. 


\section{RESULTADOS}

\subsection{Aspectos descritivos da população de estudo}

Inicialmente, assinaram o termo de consentimento e responderam ao questionário 345 presos. Contudo, somente 333 foram submetidos à coleta de sangue, tendo ocorrido 12 desistências no momento da coleta.

As tabelas de 1 a 9 são apenas descritivas e mostram características gerais da população estudada. As tabelas seguintes apresentam a análise da distribuição da sorologia para o $\mathrm{HBV}$ e HCV, de acordo com diferentes variáveis, e constituem o estudo da associação entre a exposição a esse vírus e seus possíveis fatores preditores.

Conforme pode ser visto na Tabela 1, existia no início dessa investigação um total de 893 presidiários dispostos em quatro pavilhões, com uma distribuição numérica muito semelhante em três deles (2, 3 e 4) e um valor menor no pavilhão 1 (189). Os 333 participantes desse estudo representam $37,3 \%$ do total de presidiários inicialmente encontrados nos quatro pavilhões, com um predomínio percentual de participação dos residentes no pavilhão 1 (46,0\%) e uma distribuição que oscilou entre 32,9\% e 36,4\% nos demais. Vale frisar que existiam ainda outros 138 presidiários, incluindo-se os do "seguro" e os da ala de progressão continuada (APP), perfazendo um total de 1030 pessoas. Assim, o percentual de participação em relação à totalidade da população do presídio foi de 32,3\% (333/1030). 
Tabela 1 - Distribuição dos presidiários nos pavilhões estudados e seus respectivos participantes. Penitenciária de Ribeirão Preto, 2003.

\begin{tabular}{cccc}
\hline \multirow{2}{*}{ PAVILHÃO } & NÚMERO DE & \multicolumn{2}{c}{ PARTICIPANTES } \\
\cline { 3 - 4 } & PRESIDIÁRIOS & $\mathrm{n}$ & $\%$ \\
\hline 1 & 189 & 87 & 46,0 \\
2 & 234 & 83 & 35,5 \\
3 & 236 & 86 & 36,4 \\
4 & 234 & 77 & 32,9 \\
\hline Total & 893 & 333 & 37,3 \\
\hline
\end{tabular}

Em relação a variável idade (Tabela 2), os presidiários apresentavam uma média de 30,1 anos com desvio padrão de 8,2. A mediana é de 28 anos e a amplitude de variação mostrou-se consideravelmente larga, variando de 19 a 69 anos.

Tabela 2 - Valores da média, desvio padrão, mediana e amplitude de variação da idade nos presidiários. Penitenciária de Ribeirão Preto, 2003.

\begin{tabular}{cc}
\hline IDADE & PRESIDIÁRIO \\
\hline Média & 30,06 \\
Desvio padrão & 8,18 \\
Mediana & 28 \\
Amplitude de variação & 19 a 69 \\
\hline
\end{tabular}


O estudo dos participantes segundo o pavilhão e o grupo etário (Tabela 3) revela uma concentração nos grupos de 25 a 30 anos (32,1\%) e de 19 a 24 anos (28,9\%), mostrando que até os 30 anos de idade concentram-se mais de $60 \%$ deles. Os grupos de 31 a 35 e de 36 a 45 anos participam com percentuais menores e muito próximos entre si $(16,5 \%$ e $18 \%$, respectivamente). No extremo superior de idade ( $>45$ anos) observa-se o mais baixo percentual de participação (4,5\%). A superioridade do grupo de 25 a 30 se dá, predominantemente, nos pavilhões 1 e 2 (32,2\% e 34,9\%, respectivamente). Por outro lado, o grupo de 19 a 24 anos tem uma participação maior nos pavilhões 3 e 4 (34,9\% e 6,3\%, respectivamente).

Tabela 3 - Distribuição dos presidiários segundo idade e pavilhão. Penitenciária de Ribeirão Preto, 2003.

\begin{tabular}{ccccccccccc}
\hline \multirow{2}{*}{ FAIXA } & \multicolumn{10}{c}{ PAVILHÃO } \\
\cline { 2 - 11 } ETÁRIA & \multicolumn{1}{c}{1} & \multicolumn{1}{c}{2} & \multicolumn{1}{c}{3} & & 4 & \multicolumn{2}{c}{ Total } \\
\cline { 2 - 11 } & $\mathrm{n}$ & $\%$ & $\mathrm{n}$ & $\%$ & $\mathrm{n}$ & $\%$ & $\mathrm{n}$ & $\%$ & $\mathrm{n}$ & $\%$ \\
\hline 19-24 anos & 17 & 19,6 & 21 & 25,3 & 30 & 34,9 & 28 & 36,3 & 96 & 28,9 \\
25-30 anos & 28 & 32,2 & 29 & 34,9 & 27 & 31,4 & 23 & 29,9 & 107 & 32,1 \\
31-35 anos & 13 & 14,9 & 15 & 18,1 & 16 & 18,6 & 11 & 14,3 & 55 & 16,5 \\
36-45 anos & 23 & 26,4 & 16 & 19,3 & 11 & 12,8 & 10 & 13,0 & 60 & 18,0 \\
$>45$ anos & 06 & 6,9 & 02 & 2,4 & 02 & 2,3 & 05 & 6,5 & 15 & 4,5 \\
\hline Total & 87 & 100,0 & 83 & 100,0 & 86 & 100,0 & 77 & 100,0 & 333 & 100,0
\end{tabular}


A Tabela 4 mostra que a maioria dos participantes nasceu em cidades da região de Ribeirão Preto $(31,6 \%)$, seguida dos nascidos em outra região do Estado de São Paulo (24,6\%) e nos outros estados do País (22,5\%). Nascidos em Ribeirão Preto representam 21,3\% dos participantes, concentrando-se de modo mais evidente no pavilhão 1 (28,7\%), quando comparado aos demais.

Tabela 4 - Distribuição dos presidiários segundo local de nascimento e pavilhão. Penitenciária de Ribeirão Preto, 2003.

\begin{tabular}{|c|c|c|c|c|c|c|c|c|c|c|}
\hline \multirow{3}{*}{$\begin{array}{c}\text { LOCAL DE } \\
\text { NASCIMENTO }\end{array}$} & \multicolumn{10}{|c|}{ PAVILHÃO } \\
\hline & \multicolumn{2}{|r|}{1} & \multicolumn{2}{|r|}{2} & \multicolumn{2}{|r|}{3} & \multicolumn{2}{|r|}{4} & \multicolumn{2}{|c|}{ Total } \\
\hline & $\mathrm{n}$ & $\%$ & $\mathrm{n}$ & $\%$ & $\mathrm{n}$ & $\%$ & $\mathrm{n}$ & $\%$ & $\mathrm{n}$ & $\%$ \\
\hline $\begin{array}{l}\text { Ribeirão Preto } \\
\text { Região de }\end{array}$ & 25 & 28,7 & 16 & 19,3 & 16 & 18,6 & 14 & 18,2 & 71 & 21,3 \\
\hline $\begin{array}{l}\text { Ribeirão Preto } \\
\text { Outra região de }\end{array}$ & 25 & 28,7 & 27 & 32,5 & 28 & 32,6 & 25 & 32,4 & 105 & 31,6 \\
\hline São Paulo & 18 & 20,7 & 20 & 24,1 & 22 & 25,6 & 22 & 28,6 & 82 & 24,6 \\
\hline Outro estado & 19 & 21,9 & 20 & 24,1 & 20 & 23,2 & 16 & 20,8 & 75 & 22,5 \\
\hline Total & 87 & 100,0 & 83 & 100,0 & 86 & 100,0 & 77 & 100,0 & 333 & 100,0 \\
\hline
\end{tabular}

Analisando-se o local de residência (Tabela 5), verifica-se que apenas $3 \%$ têm moradia fixada fora do Estado de São Paulo e 21,3\% em outras regiões do Estado. Chama atenção que mais de três quartos dos participantes moravam em Ribeirão Preto e região (34,8\% na cidade e 40,9\% na região). A distribuição dentro dos pavilhões evidencia predomínio dos que residem na cidade de Ribeirão Preto, entre os habitantes do pavilhão $1(54,0 \%)$. 
Tabela 5 - Distribuição dos presidiários segundo local de residência e pavilhão. Penitenciária de Ribeirão Preto, 2003.

\begin{tabular}{|c|c|c|c|c|c|c|c|c|c|c|}
\hline \multirow{3}{*}{$\begin{array}{c}\text { LOCAL DE } \\
\text { RESIDÊNCIA }\end{array}$} & \multicolumn{10}{|c|}{ PAVILHÃO } \\
\hline & \multicolumn{2}{|r|}{1} & \multicolumn{2}{|r|}{2} & \multicolumn{2}{|r|}{3} & \multicolumn{2}{|r|}{4} & \multicolumn{2}{|c|}{ Total } \\
\hline & $\mathrm{n}$ & $\%$ & $\mathrm{n}$ & $\%$ & $\mathrm{n}$ & $\%$ & $\mathrm{n}$ & $\%$ & $\mathrm{n}$ & $\%$ \\
\hline $\begin{array}{l}\text { Ribeirão Preto } \\
\text { Região de }\end{array}$ & 47 & 54,0 & 27 & 32,5 & 23 & 26,8 & 19 & 24,7 & 116 & 34,8 \\
\hline $\begin{array}{c}\text { Ribeirão Preto } \\
\text { Outra região }\end{array}$ & 28 & 32,2 & 34 & 41,0 & 43 & 50,0 & 31 & 40,2 & 136 & 40,9 \\
\hline de São Paulo & 11 & 12,6 & 18 & 21,7 & 18 & 20,9 & 24 & 31,2 & 71 & 21,3 \\
\hline Outro estado & 01 & 1,2 & 04 & 4,8 & 02 & 2,3 & 03 & 3,9 & 10 & 3,0 \\
\hline Total & 87 & 100,0 & 83 & 100,0 & 86 & 100,0 & 77 & 100,0 & 333 & 100,0 \\
\hline
\end{tabular}

A distribuição em relação ao estado civil (Tabela 6) revela que praticamente a metade dos participantes (49,0\%) situa-se na categoria "amasiado", com a segunda colocação sendo ocupada pelos solteiros $(32,7 \%)$. Casados e divorciados/viúvos mostram percentuais semelhantes e bastante inferiores aos grupos anteriormente mencionados (9,0\% e 9,3\%, respectivamente). Comparado aos demais, o pavilhão 1 concentra percentuais mais elevados de indivíduos casados. 
Tabela 6 - Distribuição dos presidiários segundo estado civil e pavilhão. Penitenciária de Ribeirão Preto, 2003

\section{PAVILHÃO}

\begin{tabular}{|c|c|c|c|c|c|c|c|c|c|c|}
\hline \multirow[t]{2}{*}{$\begin{array}{l}\text { ESTADO } \\
\text { CIVIL }\end{array}$} & \multicolumn{2}{|r|}{1} & \multicolumn{2}{|c|}{2} & \multicolumn{2}{|r|}{3} & \multicolumn{2}{|r|}{4} & \multicolumn{2}{|c|}{ Total } \\
\hline & $\mathrm{n}$ & $\%$ & $\mathrm{n}$ & $\%$ & $\mathrm{n}$ & $\%$ & $\mathrm{n}$ & $\%$ & $\mathrm{n}$ & $\%$ \\
\hline Casado & 12 & 13,8 & 07 & 8,4 & 05 & 5,8 & 06 & 7,8 & 30 & 9,0 \\
\hline Solteiro & 19 & 21,8 & 33 & 39,7 & 34 & 39,5 & 23 & 29,9 & 109 & 32,7 \\
\hline Amasiado & 39 & 44,8 & 40 & 48,3 & 44 & 51,2 & 40 & 51,9 & 163 & 49,0 \\
\hline $\begin{array}{c}\text { Divorciado - } \\
\text { viúvo }\end{array}$ & 17 & 19,6 & 03 & 3,6 & 03 & 3,5 & 08 & 10,4 & 31 & 9,3 \\
\hline Total & 87 & 100,0 & 83 & 100,0 & 86 & 100,0 & 77 & 100,0 & 333 & 100,0 \\
\hline
\end{tabular}

A Tabela 7 mostra a distribuição dos participantes segundo história de consumo de drogas ilícitas não injetáveis, bem como dos tipos de drogas referidas. Percebe-se um amplo consumo dessas drogas na população de estudo, com menos de um quinto dos participantes negando o seu uso em algum momento da vida $(18,6 \%)$. Como droga de uso isolado, referida por 108 (32,4\%) dos presidiários, destaca-se a maconha. Esta substância ilícita, quando associada ao crack e/ou cocaína, eleva seu consumo para mais de 70\% (234/333) do total de participantes. Em relação aos pavilhões, os de número 3 e 4 relatam maiores percentuais de uso de maconha isoladamente (37,2\% e $37,6 \%$, respectivamente), quando comparados aos pavilhões 1 e 2 . Quando se consideram combinações de drogas, a associação maconha/cocaína é a mais relatada (19,3\%), seguida por maconha/cocaína/crack (14,7\%). Cocaína, isolada ou combinada, ocupa o segundo lugar na preferência de uso (38,7\%, ou 129/333), seguida do crack, também isolado ou combinado $(22,2 \%, 74 / 333)$. 
Tabela 7 - Distribuição dos presidiários segundo tipo de droga não injetável usada no passado e pavilhão. Penitenciária de Ribeirão Preto, 2003.

\begin{tabular}{|c|c|c|c|c|c|c|c|c|c|c|}
\hline \multirow{3}{*}{$\begin{array}{c}\text { TIPO DE } \\
\text { DROGA } \\
\text { NÃO } \\
\text { INJETÁVEL }\end{array}$} & \multicolumn{10}{|c|}{ PAVILHÃO } \\
\hline & \multicolumn{2}{|r|}{1} & \multicolumn{2}{|r|}{2} & \multicolumn{2}{|c|}{3} & \multicolumn{2}{|r|}{4} & \multicolumn{2}{|c|}{ Total } \\
\hline & $\mathrm{n}$ & $\%$ & $\mathrm{n}$ & $\%$ & $\mathrm{n}$ & $\%$ & $\mathrm{n}$ & $\%$ & $\mathrm{n}$ & $\%$ \\
\hline Maconha & 27 & 31,1 & 20 & 24,1 & 32 & 37,2 & 29 & 37,6 & 108 & 32,4 \\
\hline Cocaína & 03 & 3,4 & 03 & 3,6 & 02 & 2,3 & 02 & 2,6 & 10 & 3,0 \\
\hline Crack & 02 & 2,3 & 02 & 2,4 & 00 & 0,0 & 02 & 2,6 & 06 & 1,8 \\
\hline $\begin{array}{l}\text { Maconha/ } \\
\text { Cocaína }\end{array}$ & 19 & 21,9 & 14 & 16,9 & 14 & 16,3 & 17 & 22,1 & 64 & 19,3 \\
\hline $\begin{array}{c}\text { Maconha/ } \\
\text { Crack }\end{array}$ & 05 & 5,7 & 03 & 3,6 & 03 & 3,5 & 02 & 2,6 & 13 & 3,9 \\
\hline $\begin{array}{l}\text { Crack/ } \\
\text { Cocaína }\end{array}$ & 02 & 2,3 & 01 & 1,2 & 02 & 2,3 & 01 & 1,3 & 06 & 1,8 \\
\hline $\begin{array}{l}\text { Maconha/ } \\
\text { Crack/ } \\
\text { Cocaína }\end{array}$ & 09 & 10,3 & 14 & 16,9 & 16 & 18,7 & 10 & 13,0 & 49 & 14,7 \\
\hline Outros tipos & 05 & 5,7 & 03 & 3,6 & 02 & 2,3 & 05 & 6,5 & 15 & 4,5 \\
\hline $\begin{array}{c}\text { Nunca } \\
\text { usaram }\end{array}$ & 15 & 17,3 & 23 & 27,7 & 15 & 17,4 & 09 & 11,7 & 62 & 18,6 \\
\hline Total & 87 & 100,0 & 83 & 100,0 & 86 & 100,0 & 77 & 100,0 & 333 & 100,0 \\
\hline
\end{tabular}


O uso de drogas não injetáveis segundo a faixa etária (Tabela 8) revela uma nítida tendência decrescente à medida que aumenta a idade, passando de 88,5\%, entre os mais jovens, a 53,3\% entre aqueles acima de 45 anos $\left(\chi^{2}\right.$ para tendência linear $\left.=16,715 ; p<0,0001\right)$. Destaca-se novamente o enorme consumo de drogas ilícitas não injetáveis nos presidiários estudados, atingindo $81,4 \%$ deles. Agrupando-se as faixas etárias "19 a 24" com "25 a 30", e cotejando-as com o agrupamento formado pelas demais, verifica-se associação estatisticamente significante entre as variáveis $\left(\chi_{(1 \mathrm{GL})}^{2}=11,58 ; \mathrm{p}=0,001\right)$.

Tabela 8 - Distribuição dos presidiários segundo idade e uso de drogas ilícitas não injetáveis. Penitenciária de Ribeirão Preto, 2003.

\begin{tabular}{ccccccc}
\hline & \multicolumn{2}{c}{ DROGAS NÃO INJETÁVEIS } \\
\cline { 2 - 7 } FAIXA ETÁRIA & \multicolumn{2}{c}{ SIM } & \multicolumn{2}{c}{ NÃO } & \multicolumn{2}{c}{ Total } \\
\cline { 2 - 7 } & $\mathrm{n}$ & $\%$ & $\mathrm{n}$ & $\%$ & $\mathrm{n}$ & $\%$ \\
\cline { 2 - 7 } 19-24 anos & 85 & 88,5 & 11 & 11,5 & 96 & 100,0 \\
$25-30$ anos & 92 & 86,0 & 15 & 14,0 & 107 & 100,0 \\
$31-35$ anos & 45 & 81,8 & 10 & 18,2 & 55 & 100,0 \\
$36-45$ anos & 41 & 68,3 & 19 & 31,7 & 60 & 100,0 \\
$>45$ anos & 8 & 53,3 & 7 & 46,7 & 15 & 100,0 \\
\hline Total & 271 & 81,4 & 62 & 18,6 & 333 & 100,0 \\
\hline$p=0,001$ & & & & & &
\end{tabular}

A análise do uso de drogas injetáveis (Tabela 9) mostrou, no geral, sensível diferença quanto ao item anterior. Observa-se baixo consumo deste tipo de droga (8,7\%), mais concentrada nos participantes de 31 a 35 anos (21,8\%) e de 36 a 45 anos (10,0\%). Chama atenção a não referência ao uso de drogas injetáveis entre os presos com idade acima de 45 anos. Agrupando-se as faixas etárias até 30 anos e as de 31 ou mais, verifica-se associação entre as variáveis $\left(\chi^{2}{ }_{(1 \mathrm{GL})}=7,07 ; p=0,008\right)$. 
Tabela 9 - Distribuição dos presidiários segundo idade e uso de drogas ilícitas injetáveis. Penitenciária de Ribeirão Preto, 2003.

\begin{tabular}{ccccccc}
\hline \multirow{2}{*}{ FAIXA ETÁRIA } & \multicolumn{3}{c}{ DROGAS INJETÁVEIS } \\
\cline { 2 - 7 } & \multicolumn{2}{c}{ SIM } & \multicolumn{2}{c}{ NÃO } & \multicolumn{2}{c}{ Total } \\
\cline { 2 - 7 } & $\mathrm{n}$ & $\%$ & $\mathrm{n}$ & $\%$ & $\mathrm{n}$ & $\%$ \\
\hline 19-24 anos & 04 & 4,2 & 92 & 95,8 & 96 & 100,0 \\
$25-30$ anos & 07 & 6,5 & 100 & 93,5 & 107 & 100,0 \\
$31-35$ anos & 12 & 21,8 & 43 & 78,2 & 55 & 100,0 \\
$36-45$ anos & 06 & 10,0 & 54 & 90,0 & 60 & 100,0 \\
$>45$ anos & 00 & 0,0 & 15 & 100,0 & 15 & 100,0 \\
\hline Total & 29 & 8,7 & 304 & 91,3 & 333 & 100,0 \\
\hline $\mathrm{p}=0,008$ & & & & & &
\end{tabular}

\subsection{Resultados do estudo de associação entre infecção pelo HBV e HCV e possíveis fatores de riscos respectivos}

Para infectado pelo HBV, foram considerados os participantes que apresentaram o seguinte perfil de marcadores para este vírus: HBsAg e anti$\mathrm{HBc}$ total reagentes; anti-HBc total e anti-HBs reagentes; HBsAg reagente isoladamente; e anti-HBc total reagente isoladamente. $\mathrm{Na}$ Tabela 10 , visualiza-se a distribuições dos marcadores em cada uma dessas situações. Observa-se que a maioria dos testados (43/65) já apresenta resolução do quadro e, chama a atenção, o número 18,5\% (12/65) de presos com infecção em atividade. O percentual com HBsAg reagente é 3,6\% (12/333). A positividade de exposição para o HBV ocorreu em 65 presos, representando um valor de prevalência total igual a 19,5\% (IC $95 \%$ : 15,2 23,8). Encontrou-se que, 9,9\% (33/333) dos indivíduos apresentaram, isoladamente, apenas presença do anti-HBs, sugerindo vacinação prévia, porém não houve questionamento aos presos sobre vacina para hepatite B. 
Tabela 10 - Distribuição dos marcadores do HBV nos presidiários expostos. Penitenciária de Ribeirão Preto, 2003.

\begin{tabular}{ccc}
\hline Marcadores HBV positivos & $\mathrm{N}$ & $\%$ \\
\hline HBsAg e anti-HBC & 04 & 6,1 \\
anti-HBs e anti-HBC & 43 & 66,2 \\
HBsAg isolado & 08 & 12,3 \\
anti-HBc isolado & 10 & 15,4 \\
Total & 65 & 100,0 \\
\hline
\end{tabular}

Em relação à hepatite $C$ (Tabela 11), foram considerados expostos aqueles participantes que apresentaram o marcador anti-HCV reagente. Isto ocorreu em 29 presidiários, estimando o valor de prevalência total igual a 8,7\% (IC $95 \%: 5,7$ - 11,7). Destes com sorologia reagente, 25 soros apresentaram infecção em atividade por presença do HCV RNA.

Tabela 11 - Distribuição dos marcadores do HCV nos presidiários. Penitenciária de Ribeirão Preto, 2003.

Marcadores HCV positivos $\mathrm{N}$

Anti-HCV $29 *$

HCV RNA 25

* 28 presos mantiveram positividade pelo método imunocromatográfico. 
Nas tabelas seguintes serão mostradas algumas co-variáveis e suas associações às positividades ao HBV e HCV.

\subsubsection{Estudo do HBV com "faixa etária" e "escolaridade" isoladamente}

A distribuição dos portadores do HBV dentro dos grupos etários (Tabela 12) mostra-se ser significantemente maior nos presos de 31 a 35 anos $(29,1 \%)$ e nos de 36 a 45 anos (33,3\%) e acima de 45 anos (33,3\%). Os indivíduos mais jovens mostram valores de prevalência mais reduzidos, com 6,3\% entre 19 e 24 anos. Já os que estão entre 25 e 30 anos de idade, o valor é intermediário entre mais jovens e mais velhos (16,8\%). Agrupando-se as faixas etárias em duas - até 30 e acima de 30 anos - encontra-se forte associação estatística com a presença da infecção pelo HBV ( $\chi^{2}{ }_{(1 G L)}=$ 19,60; $p=0,000)$.

Tabela 12 - Distribuição dos presidiários segundo idade e infecção do HBV. Penitenciária de Ribeirão Preto, 2003.

\begin{tabular}{ccccccc}
\hline & \multicolumn{7}{c}{ INFECÇÃO HBV } \\
\cline { 2 - 7 } FAIXA ETÁRIA & \multicolumn{2}{c}{ POSITIVO } & \multicolumn{2}{c}{ NEGATIVO } & \multicolumn{2}{c}{ Total } \\
\cline { 2 - 7 } & $\mathrm{n}$ & $\%$ & $\mathrm{n}$ & $\%$ & $\mathrm{n}$ & $\%$ \\
\hline 19-24 anos & 06 & 6,3 & 90 & 93,7 & 96 & 100,0 \\
$25-30$ anos & 18 & 16,8 & 89 & 83,2 & 107 & 100,0 \\
$31-35$ anos & 16 & 29,1 & 39 & 70,9 & 55 & 100,0 \\
$36-45$ anos & 20 & 33,3 & 40 & 66,7 & 60 & 100,0 \\
$>45$ anos & 05 & 33,3 & 10 & 66,7 & 15 & 100,0 \\
\hline Total & 65 & 19,5 & 268 & 80,5 & 333 & 100,0 \\
\hline $\mathrm{p}=0,000$ & & & & & &
\end{tabular}


A Tabela 13 revela que os extremos do tempo de escolaridade têm distribuições inversamente proporcionais à presença sorológica ao HBV, variando de $10,0 \%$, nos mais escolarizados, a $25,5 \%$ naqueles com menos tempo na escola. Em segundo lugar vem o grupo de 5 a 8 anos, com 20,0\% de positividade. O grupo de 2 a 5 anos tem uma prevalência de 19,7\% e reúne $44,6 \%(29 / 65)$ dos reagentes detectados. No geral, destaca-se o reduzido nível de escolaridade da população de estudo, com a maioria situando-se entre 2 e 5 anos de freqüência à escola (147/333, ou 44,1\%) e somente $12,0 \%$ (40/333) com pelo menos o colegial concluído. Agrupandose as categorias de escolaridade até 8 anos e acima desta faixa, a análise estatística não evidencia diferenças significativas (teste exato de Fisher: $p=$ $0,136)$.

Tabela 13 - Distribuição dos presidiários segundo escolaridade e infecção do HBV. Penitenciária de Ribeirão Preto, 2003.

\begin{tabular}{|c|c|c|c|c|c|c|}
\hline \multirow{3}{*}{ ESCOLARIDADE } & \multicolumn{6}{|c|}{ INFECÇÃO HBV } \\
\hline & \multicolumn{2}{|c|}{ POSITIVO } & \multicolumn{2}{|c|}{ NEGATIVO } & \multicolumn{2}{|c|}{ Total } \\
\hline & $\mathrm{n}$ & $\%$ & $\mathrm{n}$ & $\%$ & $\mathrm{n}$ & $\%$ \\
\hline Até 2 anos & 13 & 25,5 & 38 & 74,5 & 51 & 100,0 \\
\hline 2 a 5 anos & 29 & 19,7 & 118 & 80,3 & 147 & 100,0 \\
\hline 5 a 8 anos & 19 & 20,0 & 76 & 80,0 & 95 & 100,0 \\
\hline Colegial e acima & 4 & 10,0 & 36 & 90,0 & 40 & 100,0 \\
\hline Total & 65 & 19,5 & 268 & 80,5 & 333 & 100,0 \\
\hline
\end{tabular}




\subsubsection{Estudo do HCV com "faixa etária" e "escolaridade" isoladamente}

A distribuição dos infectados do HCV nos grupos etários (Tabela 14) apresenta-se maior nos presos de 36 a 45 anos (20,0\%), nos de 31 a 35 anos $(14,5 \%)$, seguido de perto da faixa acima de 45 anos $(13,3 \%)$. Os indivíduos mais jovens mostram valores de prevalência mais reduzidos com $5,6 \%$ entre 25 e 30 anos e, com destaque, os de menor faixa etária (19-24 anos) com apenas um representante (1,0\%) com sorologia reagente ao HCV. Agrupando-se as faixas etárias em duas - até 30 e acima de 30 anos - encontra-se associação estatística significativa com positividade ao HCV (teste exato de Fisher: $p=0,000$ ).

Tabela 14 - Distribuição dos presidiários segundo idade e infecção do HCV. Penitenciária de Ribeirão Preto, 2003.

\begin{tabular}{ccccccc}
\hline & \multicolumn{7}{c}{ INFECÇÃO HCV } \\
\cline { 2 - 7 } FAIXA ETÁRIA & \multicolumn{2}{c}{ POSITIVO } & \multicolumn{2}{c}{ NEGATIVO } & \multicolumn{2}{c}{ Total } \\
\cline { 2 - 7 } & $\mathrm{n}$ & $\%$ & $\mathrm{n}$ & $\%$ & $\mathrm{n}$ & $\%$ \\
\hline 19-24 anos & 01 & 1,0 & 95 & 99,0 & 96 & 100,0 \\
$25-30$ anos & 06 & 5,6 & 101 & 94,4 & 107 & 100,0 \\
$31-35$ anos & 08 & 14,5 & 47 & 85,5 & 55 & 100,0 \\
$36-45$ anos & 12 & 20,0 & 48 & 80,0 & 60 & 100,0 \\
$>45$ anos & 02 & 13,3 & 13 & 86,7 & 15 & 100,0 \\
\hline Total & 29 & 8,7 & 304 & 91,3 & 333 & 100,0 \\
\hline $\mathrm{p}=0,000$ & & & & & &
\end{tabular}


A Tabela 15 apresenta os infectados pelo $\mathrm{HCV}$ se concentrando menos nos dois opostos de escolaridade, até 2 anos com 5,9\% e colegial e acima com 7,5\%. O grupo de presos onde a presença do anti-HCV reagente foi mais elevado é o de 5 a 8 anos com 10,5\%. Já o de 2 a 5 anos, revelou maior quantidade de indivíduos contaminados, 44,8\% (13/29). Agrupando-se as categorias de escolaridade até 8 anos e acima desta faixa, a análise estatística não evidencia significância (teste exato de Fisher: $p=1,000$ ).

Tabela 15 - Distribuição dos presidiários segundo escolaridade e infecção do HCV. Penitenciária de Ribeirão Preto, 2003.

\begin{tabular}{crrrrrrc}
\hline & \multicolumn{7}{c}{ SOROLOGIA HCV } \\
\cline { 2 - 8 } ESCOLARIDADE & \multicolumn{2}{c}{ POSITIVO } & \multicolumn{2}{c}{ NEGATIVO } & \multicolumn{2}{c}{ Total } \\
\cline { 2 - 8 } & $\mathrm{n}$ & $\%$ & $\mathrm{n}$ & $\%$ & $\mathrm{n}$ & $\%$ \\
\hline Até 2 anos & 3 & 5,9 & 48 & 94,1 & 51 & 100,0 \\
2 a 5 anos & 13 & 8,8 & 134 & 91,2 & 147 & 100,0 \\
5 a 8 anos & 10 & 10,5 & 85 & 89,5 & 95 & 100,0 \\
Colegial e acima & 3 & 7,5 & 37 & 92,5 & 40 & 100,0 \\
\hline Total & 29 & 8,7 & 304 & 91,3 & 333 & 100,0 \\
\hline $\mathrm{p}=1,000$ & & & & & &
\end{tabular}

\subsubsection{Estudo do HBV e HCV em conjunto com outras variáveis}

A distribuição segundo tempo da pena total é mostrada na Tabela 16. Percebe-se que a positividade ao HBV concentrou-se mais (50/65) nos indivíduos com pena maior que 5 anos. A presença da infecção pelo vírus da hepatite B mostra-se diretamente proporcional ao tempo de pena, com $16,1 \%$ naqueles com até 5 anos e 20,8\% entre os condenados a mais de 5 anos. A análise estatística não mostra associação entre as variáveis (teste exato de Fisher: $p=0,359$ ). Em relação ao HCV, os infectados são em maior quantidade em números absolutos (19/29) nos participantes com pena total acima de 5 anos, porém, em números relativos, há mais portadores nos indivíduos com até 5 anos de pena. Não há significância estatística entre HCV e tempo da pena total (teste exato de Fisher: $p=0,395$ ). 
Tabela 16 - Distribuição dos presidiários segundo tempo da pena total e infecção do HBV e HCV. Penitenciária de Ribeirão Preto, 2003.

\begin{tabular}{c|ccc|cccc}
\hline TEMPO & \multicolumn{3}{|c|}{$\mathrm{HBV}^{*}$} & \multicolumn{3}{c}{ HCV** } \\
\cline { 2 - 8 } $\begin{array}{c}\text { DA PENA } \\
\text { TOTAL }\end{array}$ & $(+)$ & $\mathrm{n}$ & $\mathrm{Pos}(\%)$ & $(+)$ & $\mathrm{n}$ & $\mathrm{Pos}(\%)$ \\
\hline Até 5 anos & 15 & 93 & $(16,1)$ & 10 & 93 & $(10,8)$ \\
Acima de 5 anos & 50 & 240 & $(20,8)$ & 19 & 240 & $(7,9)$ \\
\hline Total & 65 & 333 & $(19,5)$ & 29 & 333 & $(8,7)$ \\
\hline
\end{tabular}

$\mathrm{Na}$ Tabela 17, vale destacar o elevado número de presos (269/333) com pena cumprida até 5 anos. Os indivíduos que estão encarcerados acima de 5 anos representam 25\% de infectados pelo HBV, enquanto nos até 5 anos, 18,2\%. Na avaliação estatística, não ocorreu significância ( $\chi^{2}(1 \mathrm{GL})$ $=1,51 ; p=0,218)$. Para o HCV, os presidiários infectados por este vírus que cumpriram mais de 5 anos da pena são 15,6\%, enquanto os de pena cumprida de até 5 anos são 7\%. Ocorreu associação estatística entre essas variáveis $\left(\chi^{2}{ }_{(1 \mathrm{GL})}=4,76 ; \mathrm{p}=0,029\right)$.

Tabela 17 - Distribuição dos presidiários segundo tempo da pena já cumprida e infecção do HBV e HCV. Penitenciária de Ribeirão Preto, 2003.

\begin{tabular}{c|ccc|cccc}
\hline \multirow{2}{*}{$\begin{array}{c}\text { TEMPO DA PENA } \\
\text { CUMPRIDA }\end{array}$} & \multicolumn{3}{|c|}{ HBV* } & \multicolumn{3}{c}{ HCV** } \\
\cline { 2 - 8 } & $(+)$ & $\mathrm{n}$ & $\mathrm{Pos}(\%)$ & $(+)$ & $\mathrm{n}$ & $\mathrm{Pos}(\%)$ \\
\hline Até 5 anos & 49 & 269 & $(18,2)$ & 19 & 269 & $(7,0)$ \\
Acima de 5 anos & 16 & 64 & $(25,0)$ & 10 & 64 & $(15,6)$ \\
\hline Total & 65 & 333 & $(19,5)$ & 29 & 333 & $(8,7)$ \\
\hline${ }^{*} \mathrm{p}=0,218 \quad * * \mathrm{p}=0,029$ & & & & &
\end{tabular}


Antecedente de DST é referido por mais de um terço (34,2\%) dos participantes (114/333), entre os quais a positividade ao vírus B da hepatite alcança 24,6\% (Tabela 18). Entre os que não apresentam antecedentes de tal doença, a prevalência do HBV atinge 16,9\%. A análise estatística não mostra associação entre as variáveis $\left(\chi^{2}{ }_{(1 G L)}=2,34 ; p=0,126\right)$. Já relacionado à infecção pelo vírus da hepatite $\mathrm{C}$, o índice de expostos a este vírus que relataram DST prévia atinge $14,0 \%$. Dos anti-HCV reagentes, mais da metade já tiveram pelo menos um tipo de DST (16/29). Existe significância estatística ao teste do Chi quadrado entre estas variáveis $\left(\chi^{2}\right.$ $(1 \mathrm{GL})=5,21 ; p=0,022)$.

Tabela 18 - Distribuição dos presidiários segundo DST prévia e infecção do HBV e HCV. Penitenciária de Ribeirão Preto, 2003.

\begin{tabular}{c|ccc|cccc}
\hline \multirow{2}{*}{ DST PRÉVIA } & \multicolumn{3}{|c|}{$\mathrm{HBV}^{*}$} & \multicolumn{4}{c}{$\mathrm{HCV}^{* *}$} \\
\cline { 2 - 8 } & $(+)$ & $\mathrm{n}$ & $\mathrm{Pos}(\%)$ & $(+)$ & $\mathrm{n}$ & Pos(\%) \\
\hline Sim & 28 & 114 & $(24,6)$ & 16 & 114 & $(14,0)$ \\
Não & 37 & 219 & $(16,9)$ & 13 & 219 & $(5,9)$ \\
\hline Total & 65 & 333 & $(19,5)$ & 29 & 333 & $(8,7)$ \\
\hline${ }^{*} p=0,126 \quad{ }^{* *} p=0,022$ & & & & &
\end{tabular}

O destaque da Tabela 19 é a presença de apenas um participante assumir sua preferência homossexual e que é o único preso infectado pelo HCV. Com relação aos portadores do vírus da hepatite B (65), a totalidade tem preferência heterossexual, apresentando 19,2\% de prevalência. Por conta disso, com estas variáveis não ocorre significância estatística (teste exato de Fisher: $p=1,000$ ). Já pelo teste estatístico aplicado a preferência sexual e HCV, não ocorre associação, embora esteja próximo do limite da significância (teste exato de Fisher: $p=0,087$ ). 
Tabela 19 - Distribuição dos presidiários segundo preferência sexual e infecção do HBV e HCV. Penitenciária de Ribeirão Preto, 2003.

\begin{tabular}{c|ccc|cccc}
\hline \multirow{2}{*}{$\begin{array}{c}\text { PREFERÊNCIA } \\
\text { SEXUAL }\end{array}$} & \multicolumn{3}{|c|}{$\mathrm{HBV}^{*}$} & \multicolumn{3}{c}{$\mathrm{HCV}^{* *}$} \\
\cline { 2 - 8 } & $(+)$ & $\mathrm{n}$ & $\mathrm{Pos}(\%)$ & $(+)$ & $\mathrm{n}$ & $\mathrm{Pos}(\%)$ \\
\hline Heterossexual & 65 & 332 & $(19,2)$ & 28 & 332 & $(8,4)$ \\
Homossexual & 00 & 01 & $(0,0)$ & 01 & 01 & $(100,0)$ \\
\hline Total & 65 & 333 & $(19,5)$ & 29 & 333 & $(8,7)$ \\
\hline$* \mathrm{p}=1,000 \quad * * \mathrm{p}=0,087$ & & & & &
\end{tabular}

Chama atenção na tabela 20, os quase $80 \%$ (264/333) dos presos negarem uso de preservativo na visita íntima. Os percentuais dos expostos aos dois vírus foram maiores no grupo que relatou uso de preservativo $(23,2$ e 13,4\%). Não foi encontrada associação estatística para HBV ((teste exato de Fisher: $p=0,155$ ) nem para HCV (teste exato de Fisher: $p=0,396$ ).

Tabela 20 - Distribuição dos presidiários segundo uso de preservativo na visita íntima e infecção do HBV e HCV. Penitenciária de Ribeirão Preto, 2003.

\begin{tabular}{c|ccc|cccc}
\hline USO DE & \multicolumn{3}{|c|}{ HBV* $_{\text {PRESERVATIVO }}$} & \multicolumn{3}{|c}{ HCV** } \\
\cline { 2 - 8 } NA VISITA ÍNTIMA & $(+)$ & $\mathrm{n}$ & $\mathrm{Pos}(\%)$ & $(+)$ & $\mathrm{n}$ & $\mathrm{Pos}(\%)$ \\
\hline Sim & 16 & 69 & $(23,2)$ & 09 & 69 & $(13,4)$ \\
Não & 49 & 264 & $(18,6)$ & 20 & 264 & $(7,6)$ \\
\hline Total & 65 & 333 & $(19,5)$ & 29 & 333 & $(8,7)$ \\
\hline
\end{tabular}

* $p=0,155 \quad$ ** $p=0,396$ 
Conforme mostrado na Tabela 21, um percentual de 45,6\% dos participantes (152/333) revela história de relacionamento sexual com parceira usuária de drogas ilícitas. As positividades aos marcadores HBV e HCV ocorrem em $23,0 \%$ e $11,8 \%$, respectivamente, daqueles com este antecedente. Já os presos que negam este comportamento, a prevalência ao HBV é $16,6 \%$ e ao $\mathrm{HCV} 6,1 \%$. O resultado do teste estatístico não demonstra associação entre o comportamento e o HBV $\left(\chi^{2}{ }_{(1 \mathrm{GL})}=2,18 ; \mathrm{p}=\right.$ $0,139)$ e nem ao $\mathrm{HCV}\left(\chi^{2}{ }_{(1 \mathrm{GL})}=3,45 ; p=0,063\right)$.

Tabela 21 - Distribuição dos presidiários segundo já ter tido relações sexuais com usuária de drogas ilícitas e infecção do HBV e HCV. Penitenciária de Ribeirão Preto, 2003.

\begin{tabular}{c|ccc|cccc}
\hline $\begin{array}{c}\text { SEXO COM } \\
\text { USUÁRIA } \\
\text { DE DROGAS ILÍCITAS }\end{array}$ & \multicolumn{3}{|c|}{$\mathrm{HBV}^{*}$} & \multicolumn{4}{c}{$\mathrm{HCV}^{* *}$} \\
\cline { 2 - 8 } & $(+)$ & $\mathrm{n}$ & $\mathrm{Pos}(\%)$ & $(+)$ & $\mathrm{n}$ & $\mathrm{Pos}(\%)$ \\
\hline Sim & 35 & 152 & $(23,0)$ & 18 & 152 & $(11,8)$ \\
Não & 30 & 181 & $(16,6)$ & 11 & 181 & $(6,1)$ \\
\hline Total & 65 & 333 & $(19,5)$ & 29 & 333 & $(8,7)$ \\
\hline$* p=0,139$ & $* * \mathrm{p}=0,063$ & & & & &
\end{tabular}

A Tabela 22 demonstra, como já enfatizado nas Tabelas 7 e 8, o marcante uso prévio da droga ilícita não injetável entre os presos (271/333). Porém, nestes, a taxa dos contaminados pelo HBV foi semelhante (19,6\%) aos que não utilizaram a droga anteriormente. Estatisticamente, as variáveis não tem associação $\left(\chi^{2}{ }_{(1 \mathrm{GL})}=0,0013 ; p=0,971\right)$. Na infecção pelo vírus da hepatite $\mathrm{C}$, todos os participantes contaminados por este agente foram usuários prévios de drogas ilícitas não injetáveis, apresentando uma prevalência de 10,7\%. Estas duas variáveis mostraram significância estatística (teste exato de Fisher: $p=0,004$ ). 
Tabela 22 - Distribuição dos presidiários segundo uso de drogas ilícitas não injetáveis no passado e sorologia HBV e HCV. Penitenciária de Ribeirão Preto, 2003.

\begin{tabular}{|c|c|c|c|c|c|c|}
\hline \multirow{2}{*}{$\begin{array}{c}\text { PASSADO } \\
\text { DE } \\
\text { DROGAS NÃO } \\
\text { INJETÁVEIS }\end{array}$} & \multicolumn{3}{|c|}{$\mathrm{HBV}^{*}$} & \multicolumn{3}{|c|}{$\mathrm{HCV}^{* *}$} \\
\hline & $(+)$ & $\mathrm{n}$ & Pos(\%) & $(+)$ & $\mathrm{n}$ & Pos(\%) \\
\hline Sim & 53 & 271 & $(19,6)$ & 29 & 271 & $(10,7)$ \\
\hline Não & 12 & 62 & $(19,4)$ & 00 & 62 & $(0,0)$ \\
\hline Total & 65 & 333 & $(19,5)$ & 29 & 333 & $(8,7)$ \\
\hline
\end{tabular}

O destaque da tabela 23 é o elevado número de 44,8\% (13/29) de exusuários de drogas ilícitas injetáveis que apresentaram sorologia reagente ao HCV. Já os presidiários sem este comportamento correspondem apenas a 5,3\% dos contaminados. A tabela ainda mostra uma positividade ao HBV quase duas vezes e meia mais elevada entre os 29 indivíduos com história de uso de drogas ilícitas injetáveis, quando comparada com o valor apresentado pelos que nunca as utilizaram (44,8 e 17,1\%, respectivamente). As análises estatísticas entre drogas injetáveis no passado e HCV (teste exato de Fisher: $p=0,000)$ e HBV $\left(\chi^{2}{ }_{(1 \mathrm{GL})}=12,95 ; p=0,000\right)$ revelam importantes associações entre as variáveis.

Tabela 23 - Distribuição dos presidiários segundo uso de drogas ilícitas injetáveis no passado e infecção do HBV e HCV. Penitenciária de Ribeirão Preto, 2003.

\begin{tabular}{|c|c|c|c|c|c|c|}
\hline \multirow{2}{*}{$\begin{array}{c}\text { PASSADO DE } \\
\text { DROGAS INJETÁVEIS }\end{array}$} & \multicolumn{3}{|c|}{$\mathrm{HBV}^{*}$} & \multicolumn{3}{|c|}{$\mathrm{HCV}^{\star *}$} \\
\hline & $(+)$ & $\mathrm{n}$ & Pos(\%) & $(+)$ & $\mathrm{n}$ & Pos(\%) \\
\hline Sim & 13 & 29 & $(44,8)$ & 13 & 29 & $(44,8)$ \\
\hline Não & 52 & 304 & $(17,1)$ & 16 & 304 & $(5,3)$ \\
\hline Total & 65 & 333 & $(19,5)$ & 29 & 333 & $(8,7)$ \\
\hline
\end{tabular}


Como visto na tabela 24, um pequeno número de participantes (11, ou $3,3 \%$ ) afirma ter história de compartilhamento de agulhas em algum momento da vida. Todavia, acima da metade e quase dois terços destes indivíduos mostram infecção ao $\operatorname{HBV}(54,5 \%)$ e ao $\operatorname{HCV}(72,7)$, respectivamente, entre eles. Os participantes que não referiram compartilhamento apresentaram prevalência quase três vezes menor ao HBV $(18,3 \%)$ e acima de onze vezes menor ao HCV (6,5\%), comparados aos que relataram tal antecedente. Tanto relacionado ao vírus da hepatite $\mathrm{B}$ (teste exato de Fisher: $p=0,009$ ) e ao vírus da hepatite $C$ (teste exato de Fisher: $p=0,000$ ), a variável compartilhamento prévio de agulha mostra ser fortemente significante.

Tabela 24 - Distribuição dos presidiários segundo compartilhamento de agulha no passado e infecção do HBV e HCV. Penitenciária de Ribeirão Preto, 2003.

\begin{tabular}{|c|c|c|c|c|c|c|}
\hline \multirow{2}{*}{$\begin{array}{c}\text { COMPARTILHAMENTO } \\
\text { DE } \\
\text { AGULHA NO PASSADO }\end{array}$} & \multicolumn{3}{|c|}{$\mathrm{HBV}^{*}$} & \multicolumn{3}{|c|}{$\mathrm{HCV}^{\star *}$} \\
\hline & $(+)$ & $\mathrm{n}$ & Pos(\%) & $(+)$ & $\mathrm{n}$ & $\operatorname{Pos}(\%)$ \\
\hline Sim & 06 & 11 & $(54,5)$ & 08 & 11 & $(72,7)$ \\
\hline Não & 59 & 322 & $(18,3)$ & 21 & 322 & $(6,5)$ \\
\hline Total & 65 & 333 & $(19,5)$ & 29 & 333 & $(8,7)$ \\
\hline
\end{tabular}

Antecedentes de transfusão sanguínea (Tabela 25) foram referidos por 9,6\% (32/333) dos participantes. Embora a positividade ao HBV neste grupo mostre um valor $(28,1 \%)$ mais elevado do que entre aqueles que não apresentam história desta exposição (18,6\%), a análise estatística não revela associação entre as variáveis $\left(\chi^{2}{ }_{(1 \mathrm{GL})}=1,66 ; p=0,196\right)$. Já em relação ao $\mathrm{HCV}$, as prevalências entre os que se submeteram e os que não se submeteram a transfusão são aproximadas $(9,4$ e $8,6 \%$, respectivamente). Neste caso, também, o teste estatístico não mostra associação (teste exato de Fisher: $p=0,750$ ). 
Tabela 25 - Distribuição dos presidiários segundo transfusão sanguínea no passado e infecção do HBV e HCV. Penitenciária de Ribeirão Preto, 2003.

\begin{tabular}{|c|c|c|c|c|c|c|}
\hline \multirow{2}{*}{$\begin{array}{l}\text { TRANSFUSÃO } \\
\text { SANGUINEA }\end{array}$} & \multicolumn{3}{|c|}{$\mathrm{HBV}^{*}$} & \multicolumn{3}{|c|}{$\mathrm{HCV}^{* *}$} \\
\hline & $(+)$ & $\mathrm{n}$ & Pos(\%) & $(+)$ & $\mathrm{n}$ & Pos(\%) \\
\hline Sim & 09 & 32 & $(28,1)$ & 03 & 32 & $(9,4)$ \\
\hline Não & 56 & 301 & $(18,6)$ & 26 & 301 & $(8,6)$ \\
\hline Total & 65 & 333 & $(19,5)$ & 29 & 333 & $(8,7)$ \\
\hline
\end{tabular}

História prévia de hepatite (Tabela 26) foi relatada por 8,1\% dos participantes (27/333), e entre eles a infecção pelo HBV é maior do que no grupo sem este antecedente (29,6 e 18,6\%, respectivamente), assim como aos contaminados ao $\mathrm{HCV}(29,6$ e 6,9\%, respectivamente). A análise estatística entre história prévia de hepatite e HBV revela um valor de "p" sem significância $\left(\chi^{2}{ }_{(1 \mathrm{GL})}=1,91 ; p=0,167\right)$, contudo, quando a primeira variável se relaciona com o HCV, há intensa associação estatística $\left(\chi^{2}{ }_{(1 \mathrm{GL})}=16,17\right.$; $p=0,001)$.

Tabela 26 - Distribuição dos presidiários segundo passado de hepatite e infecção do HBV e HCV. Penitenciária de Ribeirão Preto, 2003.

\begin{tabular}{|c|c|c|c|c|c|c|}
\hline \multirow{2}{*}{$\begin{array}{l}\text { ANTECEDENTE DE } \\
\text { HEPATITE }\end{array}$} & \multicolumn{3}{|c|}{$\mathrm{HBV}^{*}$} & \multicolumn{3}{|c|}{$\mathrm{HCV}^{* \star}$} \\
\hline & $(+)$ & $\mathrm{n}$ & Pos(\%) & $(+)$ & $\mathrm{n}$ & Pos(\%) \\
\hline Sim & 08 & 27 & $(29,6)$ & 08 & 27 & $(29,6)$ \\
\hline Não & 57 & 306 & $(18,6)$ & 21 & 306 & $(6,9)$ \\
\hline Total & 65 & 333 & $(19,5)$ & 29 & 333 & $(8,7)$ \\
\hline
\end{tabular}


Em relação ao passado de icterícia (Tabela 27), 7,2\% dos participantes relatam tal antecedente (24/333). As presenças do HBV $(29,2 \%)$ e HCV $(25,0 \%)$ nestes, alcança valor mais elevado do que o observado no grupo que não afirmou este antecedente (18,8 e 7,4\%, respectivamente). A análise estatística não mostra associação entre as variáveis passado icterícia e HBV (teste exato de Fisher: $p=0,281$ ), entretanto, mostra entre aquela e o HCV (teste exato de Fisher: $p=0,011$ ).

Tabela 27 - Distribuição dos presidiários segundo antecedente de icterícia e infecção do HBV e HCV. Penitenciária de Ribeirão Preto, 2003.

\begin{tabular}{|c|c|c|c|c|c|c|}
\hline \multirow{2}{*}{$\begin{array}{c}\text { ANTECEDENTE } \\
\text { ICTERÍCIA }\end{array}$} & \multicolumn{3}{|c|}{$\mathrm{HBV}^{*}$} & \multicolumn{3}{|c|}{$\mathrm{HCV}^{\star \star *}$} \\
\hline & $(+)$ & $\mathrm{n}$ & Pos(\%) & $(+)$ & $\mathrm{n}$ & Pos(\%) \\
\hline Sim & 07 & 24 & $(29,2)$ & 06 & 24 & $(25,0)$ \\
\hline Não & 58 & 309 & $(18,8)$ & 23 & 309 & $(7,4)$ \\
\hline Total & 65 & 333 & $(19,5)$ & 29 & 333 & $(8,7)$ \\
\hline
\end{tabular}

Observa-se na tabela 28 que mais de um terço dos presos tem tatuagem (120/333). As prevalências para HBV e HCV maiores nos reclusos que referiram presença de tatuagem, 32,5 e 19,2\%, respectivamente. Vale ressaltar, os quase $80 \%$ de expostos ao HCV que são tatuados (23/29). O estudo estatístico para o HBV não mostrou associação significativa $\left(\chi^{2}(1 \mathrm{GL})=\right.$ 0,5506; $p=0,458$ ). Para o HCV, a análise ficou próxima do limite de significância $\left(\chi^{2}(1 \mathrm{GL})=3,2457 ; p=0,072\right)$. 
Tabela 28 - Distribuição dos presidiários segundo tatuagem e infecção do HBV e HCV. Penitenciária de Ribeirão Preto, 2003.

\begin{tabular}{c|ccc|cccc}
\hline \multirow{2}{*}{ TATUAGEM } & \multicolumn{3}{|c|}{ HBV* } & \multicolumn{3}{c}{ HCV** } \\
\cline { 2 - 8 } & $(+)$ & $\mathrm{n}$ & $\mathrm{Pos}(\%)$ & $(+)$ & $\mathrm{n}$ & $\mathrm{Pos}(\%)$ \\
\hline Sim & 39 & 120 & $(32,5)$ & 23 & 120 & $(19,2)$ \\
Não & 26 & 213 & $(12,2)$ & 06 & 213 & $(2,8)$ \\
\hline Total & 65 & 333 & $(19,5)$ & 29 & 333 & $(8,7)$ \\
\hline * $\mathrm{p}=0,458 \quad * * p=0,072$ & & & & &
\end{tabular}

Na tabela 29, há uma prevalência de 5,7 de portadores do HIV entre os participantes. A co-infecção com o vírus da hepatite B é de $36,8 \%$ destes, enquanto os monoinfectados pelo vírus B são 18,5\%. Estas variáveis apresentam-se no limite da significância segundo teste estatístico aplicado $\left(\chi_{(1 \mathrm{GL})}^{2}=3,84 ; \mathrm{p}=0,050\right)$. Os portadores do HIV apresentam contaminação de até $42,1 \%$ pelo HCV, enquanto os não reagentes ao HIV mostram 6,7\%. O cálculo estatístico revela expressiva significância entre HCV e HIV (teste exato de Fisher: $p=0,000)$.

Tabela 29 - Distribuição dos presidiários segundo infecção do HIV e infecção do HBV e HCV. Penitenciária de Ribeirão Preto, 2003.

\begin{tabular}{c|ccc|cccc}
\hline \multirow{2}{*}{$\begin{array}{c}\text { INFECÇÃO } \\
\text { PELO HIV }\end{array}$} & \multicolumn{3}{|c|}{$\mathrm{HBV}^{*}$} & \multicolumn{3}{c}{ HCV** } \\
\cline { 2 - 8 } & $(+)$ & $\mathrm{n}$ & $\mathrm{Pos}(\%)$ & $(+)$ & $\mathrm{n}$ & $\mathrm{Pos}(\%)$ \\
\hline Sim & 07 & 19 & $(36,8)$ & 08 & 19 & $(42,1)$ \\
Não & 58 & 314 & $(18,5)$ & 21 & 314 & $(6,7)$ \\
\hline Total & 65 & 333 & $(19,5)$ & 29 & 333 & $(8,7)$ \\
\hline * $\mathrm{p}=0,050$ & $* * p=0,000$ & & & & &
\end{tabular}


Existe co-infecção HBV-HCV (Tabela 30) acima de 40\% entre os encarcerados. Portar os dois vírus correspondeu a 18,5\% (12/65) de todos com HBV, ao passo que os sem este agente, a taxa foi de 81,5\% (53/65). Ao término do cálculo estatístico, evidenciou-se significância na associação das variáveis $\left(\chi^{2}{ }_{(1 \mathrm{GL})}=9,66 ; p=0,002\right)$.

Tabela 30 - Distribuição dos presidiários segundo infecção do HBV e infecção do HCV. Penitenciária de Ribeirão Preto, 2003.

\begin{tabular}{ccccccc}
\hline & \multicolumn{7}{c}{ INFECÇÃO HBV } \\
\cline { 2 - 7 } INFECÇÃO & \multicolumn{7}{c}{ POSITIVO } & NEGATIVO & \multicolumn{2}{c}{ Total } \\
\cline { 2 - 7 } & $\mathrm{n}$ & $\%$ & $\mathrm{n}$ & $\%$ & $\mathrm{n}$ & $\%$ \\
\cline { 2 - 7 } Sim & 12 & 41,4 & 17 & 58,6 & 29 & 100,0 \\
Não & 53 & 17,4 & 251 & 82,6 & 304 & 100,0 \\
\hline \multirow{2}{*}{ Total } & 65 & 19,5 & 268 & 80,5 & 333 & 100,0 \\
\hline $\mathrm{p}=0,002$ & & & & & &
\end{tabular}

\subsection{Análise Multivariada}

Todas as variáveis que na análise univariada anteriormente descrita mostraram um valor de "p" igual ou menor que 0,25 foram selecionadas para análise multivariada, mediante a aplicação de um modelo de regressão logística, onde a variável resposta é a presença ou não da infecção do HBV e $\mathrm{HCV}$ e as co-variáveis estão aqui listadas com seus códigos correspondentes: 
4.3.1 Co-variáveis relacionadas com HBV:

1 Idade

1 = 31 a 69 anos; 0 = Até 30 anos

2 Escolaridade

1 = Até 8 anos; 0 = Acima de 8 anos

3 Tempo da pena cumprido

1 = Até 5 anos; 0 = Acima de 5 anos

4 DST prévia

$1=\operatorname{sim} ; 0$ = não

5 Relação sexual com usuário de drogas ilícitas

$1=\operatorname{sim} ; 0$ = não

6 Uso de drogas ilícitas injetáveis no passado

$1=\operatorname{sim} ; 0$ = não

7 Compartilhamento de agulha no passado

$1=\operatorname{sim} ; 0$ = não

8 Transfusão sanguinea

1 =sim; 0 = não

9 Antecedentes de hepatite

$1=\operatorname{sim} ; 0=$ não

10 Antecedentes de icterícia

$1=\operatorname{sim} ; 0$ = não

11 Infecção pelo HIV

$1=\operatorname{sim} ; 0$ = não

12 Infecção pelo HCV

$1=\operatorname{sim} ; 0$ = não 
4.3.2 Co-variáveis relacionadas com HCV:

1 Idade

1 = 31 a 69 anos; 0 = Até 30 anos

2 Tempo da pena cumprido

1 = Até 5 anos; $0=$ Acima de 5 anos

3 DST prévia

$1=\operatorname{sim} ; 0$ = não

4 Uso de drogas ilícitas não injetáveis previamente *

$1=\operatorname{sim} ; 0$ = não

5 Preferência sexual *

$1=\operatorname{sim} ; 0$ = não

6 Uso de preservativo na visita íntima

1 = sim; 0 = não

7 Relação sexual com usuário de drogas ilícitas

$1=\operatorname{sim} ; 0$ = não

8 Uso de drogas ilícitas injetáveis no passado

$1=\operatorname{sim} ; 0=$ não

9 Compartilhamento de agulha no passado

$1=\operatorname{sim} ; 0=$ não

10 Antecedentes de hepatite

$1=\operatorname{sim} ; 0$ = não

11 Antecedentes de icterícia

$1=\operatorname{sim} ; 0=$ não

12 Presença de tatuagem

$1=\operatorname{sim} ; 0=$ não

13 Infecção pelo HIV

$1=\operatorname{sim} ; 0$ = não

14 Infecção pelo HBV

$1=\operatorname{sim} ; 0=$ não

* variáveis excluídas da análise, apesar de p<0,25, por apresentarem freqüência zero em suas caselas. 
Nas Tabela 31 e 32, apresentamos os resultados obtidos através do modelo de regressão logística para o HBV e HCV, respectivamente.

\subsubsection{Análise multivariada para HBV}

Observa-se na Tabela 31 que a variável sexo com usuários de drogas ilícitas apresenta Odds Ratio (OR) maior que "1", indicando que existe uma associação de risco na presença desta variável em relação ao HBV. Entretanto, seus intervalos contêm o valor "1", significando que esta variável aumenta em uma vez (nada) as chances do presidiário ter sido exposto ao vírus da Hepatite B. Já o contrário ocorreu para as variáveis passado de drogas injetáveis e idade. Se o presidiário usou droga injetável no passado, a chance de ser classificado como contactante do HBV é de 2,7 comparado àquele que não as usou. No caso da idade, a chance é acima de três vezes maior para o indivíduo com idade acima de 30 anos comparado àquele abaixo de 30 anos.

Tabela 31 - Modelo de regressão logística para determinantes de prevalência para HBV. Penitenciária de Ribeirão Preto, 2003.

\begin{tabular}{l|cc}
\hline Variável & OR (95\% IC) & P \\
\hline Idade & $3,3(1,8 ; 6,1)$ & 0,0001 \\
passado drogas injetáveis & $2,7(1,9 ; 6,4)$ & 0,0220 \\
sexo com usuárias de drogas ilícitas & $1,5(0,8 ; 2,7)$ & 0,1740 \\
\hline
\end{tabular}




\subsubsection{Análise multivariada para HCV}

$\mathrm{Na}$ análise multivarida do $\mathrm{HCV}$ (Tabela 32), as variáveis idade, antecedentes de hepatite, tatuagem, passado de drogas injetáveis e compartilhamento de agulhas no passado apresentam OR maior que "1" e intervalos de confiança sem "1", indicando associação de risco na presença destas variáveis em relação ao HCV. Os presidiários que relataram hepatite previamente e uso de drogas injetáveis previamente possuem, aproximadamente, quatro vezes mais chances (3,8 e 4,1, respectivamente) de serem classificados como expostos do vírus da Hepatite C quando comparados aos que não relataram. Participantes com tatuagens, idade acima de 30 anos e passado de compartilhamento de agulhas apresentaram chances, respectivas, a contato com HCV de 3,2, 7,2 e 11,8.

Tabela 32 - Modelo de regressão logística para determinantes de prevalência para HCV. Penitenciária de Ribeirão Preto, 2003.

\begin{tabular}{l|cc}
\hline Variável & OR(95\% IC) & P \\
\hline Idade & $7,2(2,4 ; 21,3)$ & 0,0003 \\
antecedente hepatite & $3,8(1,1 ; 12,9)$ & 0,0317 \\
Tatuagem & $3,2(1,05 ; 10,0)$ & 0,0404 \\
passado droga injetável & $4,1(1,1 ; 14,2)$ & 0,0258 \\
passado compartilhamento de agulhas & $11,8(1,7 ; 82,8)$ & 0,0126 \\
\hline
\end{tabular}




\section{DISCUSSÃO}

\subsection{Considerações Gerais}

A materialização de um plano de pesquisa se conduz por uma série de passos, que inclui a escolha do objeto de estudo, elaboração do projeto, permissão para desenvolvê-lo, suporte logístico e financeiro, realização do trabalho de campo, análise dos dados e redação final do texto.

A idéia inicial da pesquisa era estudar algum grupo de indivíduos com risco elevado para aquisição de HIV, hepatite $B$, hepatite C e DSTs, como prostitutas, meninos de rua, presidiários, caminhoneiros, entre outros. Tais grupos já apresentam programas específicos de prevenção, junto à Coordenação Nacional de DST/AIDS, com relativo sucesso. A opção pelos presidiários se fez pela grande relevância do problema entre eles e pelo fato de constituírem uma população confinada, com acesso potencialmente mais fácil. Além disso, os estudos similares no Estado de São Paulo já datam de pelo menos sete anos, o que estimulava a realização de uma nova pesquisa que pudesse fornecer um instantâneo atual da infecção pelo HIV e das hepatites virais na população encarcerada. Adicionalmente, a idéia contava com o apoio do Programa de DST/AIDS da Secretaria Municipal de Saúde de Ribeirão Preto, que se dispôs a financiar a realização do teste sorológico para o HIV, bastando encontrar quem realizasse os testes para os vírus B e vírus $\mathrm{C}$ da hepatite, o que foi conseguido, posteriormente, junto ao Centro de Referência Nacional de Hepatites Virais da FIOCRUZ. O Programa de DST/AIDS da Prefeitura de Ribeirão Preto mantém trabalhos de assistência e prevenção nas três unidades prisionais da cidade, o que facilitou o contato com uma delas, a Penitenciária de Ribeirão Preto. Inaugurada há sete anos, esta instituição ainda não tinha sido objeto de estudo semelhante.

O projeto de pesquisa foi prontamente aceito pela divisão médica da Penitenciária, facilitando o aval por parte da sua diretoria. Apesar disso, o 
primeiro e mais importante impasse aconteceu neste momento. Não obstante a aquiescência da direção, havia a necessidade da concordância formal de órgãos superiores do Governo do Estado de São Paulo para a execução do projeto. A solicitação da permissão para a realização do trabalho foi entregue em meados de outubro de 2002, mas o consentimento se formalizou apenas no início de 2003. Esta espera de quase sete meses foi bastante angustiante, uma vez que sem a autorização das autoridades estaduais o projeto não poderia ter a sua aprovação final pelo Comitê de Ética em Pesquisa do Hospital das Clínicas de Ribeirão Preto.

\subsubsection{Divulgação da pesquisa entre os presidiários}

Existem comitês educacionais, comandados por professores da rede de ensino pública, que desenvolvem atividades de ensino e cultura junto aos presos. Estes educadores, por estarem em contato diário com boa parte dos encarcerados, foram o ponto inicial da divulgação da pesquisa. Todavia, logo no início dos procedimentos de campo percebeu-se que praticamente nenhum dos primeiros entrevistados tinha conhecimento adequado da natureza da investigação, o que exigiu que se pensasse na execução de algum trabalho prévio que viesse a sanar esta lacuna.

Os auxiliares de enfermagem do serviço lançaram a idéia de conversar com os assim chamados "enfermeiros" de cada um dos quatro pavilhões, representados por presos que tem um conhecimento básico da área da saúde e exercem ascendência perante os demais. Na verdade, estes indivíduos têm um papel de elo entre os colegas e a enfermaria, repassando as necessidades relacionadas à saúde do grupo, tais como: presença de medicações básicas, melhor assistência médica e odontológica, atenção aos presos mais debilitados, etc. Costumam, ainda, encaminhar pequenos rascunhos com manuscritos individuais (conhecidos como "pipa") de solicitação de algum tipo de atendimento ou realização de um determinado exame. 
A participação de tais "enfermeiros" levou a que boa parte dos presos já demonstrasse conhecimento sobre a natureza da pesquisa, ao chegar ao primeiro contato com a equipe. Mesmo assim, alguns desistiram de participar após tomarem ciência plena através das informações contidas no termo de consentimento.

\subsubsection{Inclusão dos participantes}

Como descrito na metodologia, a participação se deu por intermédio de um sorteio que envolveu 100 presos de cada um dos quatro pavilhões. A lista com os nomes dos sorteados era passada ao agente penitenciário plantonista responsável pela enfermaria, que a repassava aos seus colegas de plantão naquele determinado pavilhão. Os participantes vinham em grupos de três a quatro e, enquanto um era contatado, os outros aguardavam em uma pequena cela ao fundo da enfermaria.

Cada pessoa era abordada individualmente pelo pesquisador, que expunha todo o trabalho através de leitura das informações do termo de consentimento e complementava, se necessário, esclarecendo dúvidas que surgissem. As informações constavam basicamente de explicações sobre formas de contaminação, sinais de manifestação clínica das doenças em estudo (sífilis, infecção pelo HIV, hepatites B e C) e finalizava com a proposta de colher sangue para realização destas sorologias e responder a um questionário com dados pessoais.

Os sentenciados sorteados que não compareceram ao chamado ou compareceram, mas não se dispuseram a participar, foram repostos por outros em novo sorteio, sempre com o objetivo de alcançar 100 presidiários por pavilhão.

Percebeu-se que a grande motivação da adesão à pesquisa foi o oferecimento do teste sorológico para o HIV, embora este exame seja oferecido de rotina a todo preso, ao adentrar a penitenciária. Mesmo já no cumprimento da pena, o teste pode ser realizado por qualquer um que venha a solicitá-lo aos funcionários da divisão médica. Entretanto, ficou claro que 
mais importante do que disponibilizar a sorologia era a garantia do retorno do resultado em mãos, tendo alguns manifestado a queixa de que resultados de exames anteriores, realizados nesta ou em outras penitenciárias, não foram jamais retornados nem oralmente, muito menos devolvidos através de um documento que pudesse ser mantido em seu poder. De uma maneira geral, percebeu-se que as formas de contaminação pela hepatite $B$ e hepatite $\mathrm{C}$, ou mesmo, de estar infectado - e suas conseqüências - por estes vírus eram ignorados. Esse comportamento reflete o sentimento da população em geral, aonde exposições (sexual, sanguíneas, etc) conduziriam ao "mal maior" da infecção ao HIV, desconhecendo os riscos (muitas vezes maiores) destas práticas para outras doenças.

Ao mesmo tempo em que funcionava como estímulo para a maioria, a realização do anti-HIV surgiu como uma barreira à participação de outros. Alguns demonstraram receio de se submeter ao exame ou acreditavam não estar sob qualquer risco de contaminação. Outros evidenciaram um enorme pavor, recusando terminantemente realizar a sorologia. Dois chegaram a comentar sobre as conseqüências desastrosas de tomar conhecimento de um eventual resultado positivo nas condições de vida que levavam.

\subsubsection{Acesso e contato com os presidiários}

Quem nunca se expôs a um ambiente de presídio e nele nunca desempenhou qualquer trabalho, não tem condições de avaliar todas as peculiaridades de tal meio e as dificuldades que se colocam à execução das tarefas de uma investigação científica. Inicialmente, há o temor instintivo pelas condições de segurança pessoal, bastante presente nos primeiros dias e que foi se diluindo à medida que o tempo passava e que se percebia uma boa aceitação do trabalho por parte dos reclusos. De qualquer maneira, não se pode perder de vista que sempre existe certo componente de risco, o que torna necessário uma estrita observância das orientações fornecidas pelos funcionários. 
Para se alcançar a enfermaria, local onde foram executados os procedimentos da investigação, há necessidade de se passar por oito portões e dois detectores de metais. Além da distância, o tempo gasto podia ser aumentado se houvesse alguma viatura chegando ou algum caminhão descarregando materiais, uma vez que todos os indivíduos e veículos necessitam revista individual.

A prática de campo contrariou a idéia inicial de que o acesso aos participantes seria facilitado, por tratar-se de população confinada. Pelo contrário, inúmeros entraves acabaram por dificultar este acesso. Entre eles, a disponibilidade nem sempre constante de escolta para acompanhar o pesquisador, a necessidade da presença contínua de um agente penitenciário na enfermaria e, de modo especial, a dependência da disposição dos agentes dos pavilhões para arrebanhar os escolhidos do dia. Situações eventuais também contribuíram para inviabilizar o acesso em alguns momentos, tais como o dia em que ocorreu uma revista geral em todas as celas pela tropa de choque da Polícia Militar e uma tarde de quinta feira que coincidiu com o televisionamento de uma partida da seleção brasileira de futebol, fazendo com que nenhum dos sorteados do dia comparecesse à enfermaria.

De maneira geral, todavia, o contato com os presidiários se produziu de forma extremamente tranqüila, sem haver, em nenhum momento, qualquer tipo de estresse ou apreensão. Com raríssimas exceções, todos foram educados e se portaram de modo muito respeitoso. Caminhavam sempre com mãos para trás e cabeça abaixada, e eram orientados a somente se pronunciar se fossem inquiridos. Em determinados momentos se notava que alguns presos demonstravam receio de negar a participação, acreditando na possibilidade de advir alguma forma de prejuízo à sua pessoa. Este fato tende a ocorrer sempre que se trabalha com populações que se sintam com algum grau de dependência em relação à instituição executora da pesquisa ou ao investigador, exigindo da parte desse um investimento adicional de tempo no sentido de garantir ao indivíduo o seu absoluto direito de recusa, sem qualquer ameaça de represália. 
Os participantes apresentaram boa compreensão e aceitação do que foi proposto como objetivo da investigação. Claro que não se acredita que a participação ocorreu exclusivamente por reconhecimento da relevância de um estudo soroepidemiológico em uma população de risco. Muitos aproveitaram a oportunidade para pleitear um atendimento médico junto ao pesquisador ou reclamar de alguma carência que os afligissem. Outros solicitaram, a título de auxílio, um empenho para conseguir uma medicação, um atendimento especializado ou, até mesmo, melhor colchão para dormir. O pesquisador ajudou na medida do possível, inclusive fazendo atendimento de casos que surgiam quando não havia médico disponível, em situações como emergência hipertensiva, traumas leves, pequenos cortes e avaliação de ferida infectada. Numa ocasião, prestou assistência até aos funcionários, assinando solicitação de exames para uma dupla de agentes carcerários.

Durante a entrevista, os encarcerados demonstraram um surpreendente grau de conhecimento das formas de transmissão de DSTs e, sobretudo, do HIV, contudo, o mesmo não foi evidenciado em relação às hepatites virais. Por outro lado, essa percepção do risco de contaminação às DSTs não se traduziu no uso constante de preservativo em visita íntima, referida por apenas $20,7 \%$ deles. Outro ponto contraditório, avaliado aqui de forma subjetiva, foi a recusa em se submeter ao exame anti-HIV porque a companheira já o realizara previamente em alguma gestação, com resultado não reagente. Estes desistentes utilizaram raciocínio formal para justificar a não adesão: "se a pessoa com quem mantenho relação sexual não tem nada, eu também não tenho".

\subsubsection{Considerações sobre a aplicação do questionário}

Por conter perguntas íntimas que são essenciais na investigação de fatores de risco para DSTs e hepatites virais, já se esperava que a aplicação do questionário pudesse gerar dificuldades. Em condições ideais, a entrevista deveria se fazer em ambiente de total privacidade e com a garantia de absoluto sigilo. Infelizmente, tais condições nem sempre são 
alcançadas em um estudo com essas características - onde o espaço é dividido com funcionários da Instituição, forçando, algumas vezes, a interrupção da entrevista pela entrada de terceiros à sala.

Assim, é de se esperar algumas limitações no que diz respeito à confiabilidade de algumas questões. Contribuem para isso não só as dificuldades relacionadas ao ambiente de trabalho, mas também o estigma social que acompanha algumas práticas comportamentais. Intuitivamente, no entanto, considera-se que a confiabilidade geral das informações trabalhadas seja de um nível aceitável, em decorrência de todos os esforços empregados no sentido de se maximizá-la.

\subsubsection{Coleta dos exames de sangue}

No início da investigação, adotou-se como regra que os participantes seriam entrevistados no primeiro contato com o investigador, deixando-se a coleta de sangue para outro dia. Como este procedimento era realizado por uma auxiliar de enfermagem da penitenciária, que cumpria outras atividades e não estava integralmente disponível para a coleta, ele só podia ser executado uma ou duas vezes por semana. Com isso, alguns presos não compareceram à coleta nos dias subseqüentes, representando a perda de 12 indivíduos que já haviam sido submetidos ao questionário. A adoção de outra metodologia, em que uma enfermeira passou a ser levada diariamente ao presídio com vistas a colher a amostra de sangue logo após a entrevista, eliminou por completo o índice de perdas devidas a não retornos.

\subsection{Discussão dos Resultados}

\subsubsection{Aspectos descritivos da população estudada}

Conforme descrição anterior, a participação na pesquisa foi incrementada após envolvimento dos "enfermeiros" de cada pavilhão. A despeito deste auxílio, o de número 4 teve a menor contribuição de 
participantes em relação aos demais $(32,9 \%)$, porque muitos sorteados recusaram participar e vários desistiram da coleta de sangue. Segundo os funcionários do presídio, a baixa adesão era esperada em virtude destes presos apresentarem maior dificuldade na comunicação e relacionamento, além de problemas de indisciplina, deficiências de higiene e resistência ao desempenho de atividades relacionadas ao trabalho. A participação expressiva do pavilhão $1(46,0 \%)$ reflete a destacada atuação de seus integrantes em áreas diversas da penitenciária. Conforme relato de assistente social, estes sentenciados têm marcante envolvimento nas atividades de re-inserção à sociedade e estão sempre interessados em desempenhar alguma espécie de trabalho. Como exemplo, todos os que compõem a cozinha são integrantes desse pavilhão.

No que diz respeito a variável idade, percebe-se que a população estudada é basicamente jovem, com maior número de indivíduos de 19 a 30 anos (61,0\%). A idade média dos presidiários (30,1 anos) ficou acima dos valores verificado no Carandiru (29 anos) (MASSAD et al., 1999) e na Casa de Detenção de São Paulo (28 anos) (GUIMARÃES et al., 2001). Em outros países, encontraram-se médias de 27,2 em prisões da Cantabria (Espanha) (PALLÁS et al., 1999a); 28 anos em Nyborg (Dinamarca) (CHRISTENSEN et al., 2000) e 32,9 anos em prisões australianas (MILLER; BI; RYAN, 2006). A amplitude de variação da idade é larga, indo de um mínimo de 19 anos, onde concentra boa parte dos sentenciados, ao máximo de 69 anos, representado por um único preso. Esses achados confirmam que as atividades criminais (furto, roubo, homicídio, etc) são cometidas, majoritariamente, por indivíduos jovens.

Praticamente há uma divisão pela metade entre os participantes que nasceram na cidade de Ribeirão Preto e região (52,9\%), e os de outras áreas do Estado de São Paulo e outros Estados (47,1\%). Isso é conseqüência do recebimento de muitos presos de outras instituições do Estado por conta de super lotação de algumas delas, ou inativação de outras, como as prisões do Complexo do Carandiru. Quando se analisam estas regiões como local de residência, se constata que muitos moram em 
Ribeirão Preto e região (34,8\% e 40,9\%, respectivamente). Este achado pode ser em razão do grande potencial econômico da região de Ribeirão Preto, empregando milhares de migrantes vindos de outros Estados e regiões do Estado de São Paulo. Soma-se a isso, o deslocamento das famílias dos presos de outras regiões, sobretudo da cidade de São Paulo, transferidos para esta penitenciária para morar mais próximo dos seus. Assim, quando inquiridos sobre local de residência, os participantes referem aquele onde se localiza a sua família no momento atual, elevando os percentuais correspondentes à cidade e à região. O município que melhor representa esta situação é o de Serrana, onde muitos familiares se instalaram provenientes da Grande São Paulo acompanhando seus parentes originários do Carandiru. Como comparação, $65,8 \%$ dos reclusos no Carandiru referiu ter nascido no Estado de São Paulo (MASSAD et al., 1999).

Foram considerados como tendo parceria fixa e estável todos aqueles que referiram ser casados ou amasiados. Vale o destaque para os últimos, que representam quase metade de todos os participantes $(49,0 \%)$. Isto denota o alto nível de união civil informal, provavelmente reflexo da mesma ocorrência fora dos muros da prisão. Informalmente, alguns presos relataram que o início de um relacionamento algumas vezes se dá dentro do próprio presídio, com mulheres que seriam amigas ou parentas de colegas encarcerados. Se estes encontros persistirem nas próximas visitas, o preso já se considera "amasiado" e exige o mesmo grau de compromisso da parceira. Neste estudo, a divisão entre "casados" e "não-casados" mostra predomínio do primeiro (58\%), com um valor maior que o encontrado (48\%) em Ghaziabad, na Índia (SINGH; PRASAD; MOHANTY, 1999).

A ocorrência de doenças infecciosas entre presidiários é bastante elevada, tanto entre os que entram, como entre os que permanecem e os que saem das prisões. Este fato é demonstrado por dados de 1997 referentes à totalidade da população americana, na qual HAMMETT, HARMON e RHODES (2002) mostraram que já haviam passado pelo 
sistema penal cerca de 20 a 26\% dos portadores de HIV, 29 a 43\% dos portadores de hepatite C e $40 \%$ dos que tiveram tuberculose.

Como nossa situação certamente não se mostra melhor, intervenções se tornam necessárias para beneficiar não somente aos sentenciados e suas parcerias, mas a todo o sistema carcerário. Com este pensamento, a Penitenciária de Ribeirão Preto procura desenvolver, periodicamente, programas preventivos de DSTs e doenças transmitidas por contato com sangue. Além disso, há uma preocupação especial em fazer investigação de doenças, principalmente as mencionadas acima, entre os que adentram ao presídio. À entrada, o preso se submete a uma avaliação médica e à aplicação de um questionário com perguntas a respeito de sua saúde. Entre elas, se é portador do HIV e se já realizou testes para este vírus. Ao final, é oferecida a possibilidade deste exame, mesmo que o sentenciado se declare não portador. Esta prática explica o elevado percentual de participantes $(58,3 \%)$ que já havia sido submetido a pelo menos um exame anti-HIV. Mesmo que uma parte destes exames tenha sido feita fora da prisão, observa-se uma política de busca ativa de portadores do HIV, dentro de um contexto intimamente favorável à sua presença. Esta mesma preocupação não ocorre em relação às hepatites virais, sendo um reflexo do que ocorre na sociedade que há anos negligencia estas infecções, sobretudo o HCV, em detrimento ao HIV, tendo inclusive prevalência maior do primeiro do que do segundo em ambos os setores. A prática de oferecimento de sorologia para o HCV e HBV, além de prevenir novos casos, diminuiria a necessidade de recursos financeiros para assistência e tratamento de futuros portadores, trazendo vantagens econômicas. Mesmo assim, este oferecimento deve ser acompanhado de esclarecimentos sobre as doenças para evitar o baixo número de adesões como relatado por HORNE et al. (2004), onde apenas $12 \%$ de 3034 presos aceitou se submeter a sorologia do HCV em prisão inglesa.

$\mathrm{Na}$ população estudada, o consumo de drogas ilícitas não injetáveis no passado englobou fundamentalmente três produtos - maconha, cocaína de uso inalatório e o crack -, usados de modo isolado ou combinado. Outros 
tipos usados em menor escala foram cola, LSD, haxixe e ectasy. O percentual de uso dessas drogas foi extremamente elevado $(81,4 \%)$, com predomínio acentuado na população de até 30 anos $(p=0,001)$, apesar de uso considerável também naqueles acima desta idade. Este valor está acima do encontrado em duas unidades da FEBEM, em São Paulo (70\%) (CARVALHO et al., 2003). Na Casa de Detenção de São Paulo do Complexo do Carandiru, o uso de drogas ilícitas alcançou 73,9\% (GUIMARÃES et al., 2001).

Isoladamente, a maconha foi utilizada por $39,8 \%$ dos participantes que usaram algum tipo de droga. Este percentual sobe para 46,5\% quando ela é associada a outras drogas. Em prisão de Gana na África, observou-se taxa bem mais elevada com $83,2 \%$ dos presos que relataram utilizar maconha antes do encarceramento (ADJEl et al., 2006).

A maconha, Cannabis sativa, é a droga ilícita mais largamente consumida em muitas sociedades, principalmente ocidentais, não obstante seu uso ser proibido por lei. Seus efeitos para a saúde não são bem compreendidos e permanecem objeto de muita discussão, com opiniões polarizadas, inclusive no que concerne à legalização. Seu uso é intermitente e geralmente termina dos 25 aos 30 anos. Seus efeitos adversos podem ser agudos ou crônicos, com manifestação de bronquite crônica, ansiedade, pânico, distúrbios de memória e de atenção (HALL; SOLOWIJ, 1998). A iniciação da maconha é precedida pelo uso de substâncias lícitas (tabaco e álcool) e geralmente é a primeira droga ilícita consumida. Se utilizada precocemente (antes dos 17 anos), pode aumentar o risco de progressão para dependência ou para uso de outros tipos de substâncias (KANDEL, 2003). Paralelamente a isso, esta seqüência de drogas a partir da maconha pode também estar associada a diversos fatores, tais como pressão dos amigos, influência do tráfico, disponibilidade da droga e outras (SANCHEZ; NAPPO, 2002). Os delitos que levam a uma condenação estão intrinsecamente relacionados ao uso de drogas, com crimes como homicídios, roubos e furtos sendo, em grande parte, praticados sob sua influência. Todavia, prisões e condenações relacionadas a infrações por 
porte ou uso de maconha não necessariamente significam redução em sua utilização, podendo mesmo levar a um incremento em seu consumo (FERGUSSON; SWAIN-CAMPBELL; HORWOOD, 2003).

Chama a atenção o baixo consumo de crack, que atinge apenas 1,8\% dos participantes como droga usada isoladamente, e $22,2 \%$ quando se associa a outros tipos. Apesar de ter sido introduzido no Brasil no final da década de 1980 e início da década de 1990, o seu uso está bastante difundido e acha-se intimamente ligado à baixa escolaridade, baixo nível socioeconômico, desemprego e, sobretudo, a uma taxa mais elevada de criminalidade.

Diferentemente da elevada distribuição das drogas ilícitas não injetáveis, o uso das injetáveis anteriormente ao encarceramento foi referido por 8,7\%, mostrando uma distribuição maior entre indivíduos acima dos 30 anos $(p=0,008)$. A título de comparação com o passado recente, Lourenço, em pesquisa realizada em 1990, constatou predomínio de UDI na população de até 30 anos (79\%) (LOURENÇO, 1992). Trazendo esta faixa etária para os dias de hoje, percebe-se que é correspondente a mais prevalente nesta pesquisa. Aparentemente, o consumo dessas drogas constituía um hábito comum no passado, porém bem menos freqüente entre os mais jovens atuais. Importante lembrar que este consumo estava fortemente associado a compartilhamento de agulhas e seringas, prática que vem sendo alvo de constantes campanhas com vistas a reduzir o risco de contração de doenças transmitidas por contato sangüíneo. O oposto é encontrado em países da Ásia Central e Leste Europeu, aonde o consumo de drogas injetáveis vem mostrando elevação, e se estima que acima de $1 \%$ da população sobretudo a camada mais jovem -, utiliza drogas injetáveis. Um estudo entre estudantes secundaristas da cidade de Moscou mostrou que 4\% são UDIs, muitos com idade entre 13 e 14 anos (UNAIDS, 2002). Na presente pesquisa, chama à atenção a ausência de UDIs acima de 45 anos, o que talvez decorra do reduzido número de participantes neste grupo etário (15). 


\subsubsection{Resultados do estudo de associação de marcadores do HBV e HCV com fatores de risco.}

Diversas pesquisas de prevalência do HBV e HCV em presidiários têm permeado o meio epidemiológico. Para ilustrar bem a importância deste tema, acima de $40 \%$ de indivíduos norte americanos com hepatite viral crônica já passou por encarceramento pelo menos uma vez na vida (HAMMETT; HARMON; RHODES, 2002)

As primeiras pesquisas sobre presença da infecção do HBV nas prisões mostravam valores menores (1,5 a 8,9\%) (HOK et al., 1970; KLIMAN, 1971; KROTOSKI, 1972; MUÑIZ; MALAYSKA; LEVIN, 1971) do que este trabalho estimou (19,5\%), em virtude de avaliarem, àquela época, exclusivamente o marcador HBsAg, já que ainda não estava disponível a sorologia de contato anti-HBc. Por conseguinte, o diagnóstico era apenas feito dos casos crônicos - ou agudos - não havendo a oportunidade de serem avaliados os indivíduos contaminados que não evoluíram para a cronicidade, ou seja, a maioria dos infectados.

A investigação sobre a hepatite C no sistema carcerário se inicia, ainda antes da disponibilidade da sorologia para o HCV, em 1985 e em 1987, onde Brewer et al. (1988) realizaram pesquisa de transmissão do HIV entre presidiários. Após alguns anos, Vlahov et al. (1993) utilizaram o soro estocado nos dois estudos e demonstrou prevalência de $38,1 \%$ no primeiro e incidência de 1,1 por 100 pessoas-anos em prisão, ou seja comprovou a transmissão do HCV intra prisional. Análise realizada, logo em seguida ao início da utilização da pesquisa de anticorpos para HCV, mostrou taxa de 30,8\% em Victoria na Austrália (FAIRLEY et al., 1990).

No Brasil, os 19,5\% de prevalência para HBV achados aqui se situam abaixo dos 26,4\% encontrado por Martelli et al. (1990) em prisão de Goiás, entretanto, estão acima dos 1,89\% achados em Londrina (JABUR; BALDY; QUESADA, 1991), dos 16\% da Fundação CASA em São Paulo (CARVALHO et al., 2003) e dos 17,5\% do interior de Minas Gerais (CATALAN-SOARES; ALMEIDA; PROIETTI, 2000). Levantamento realizado na Casa de Detenção 
e na Penitenciária do Estado em 920 presidiários encontrou prevalência de $3,6 \%$ para HBsAg e $32,3 \%$ para anti-HBs, contudo esta sorologia foi realizada em apenas dois quintos dos participantes (MINKOVES, 1992).

As escassas informações sobre hepatite $C$ na população prisional brasileira se principiam com duas pesquisas distintas realizadas por volta de 1993 a 1994 no Complexo do Carandiru e na Casa de Detenção de São Paulo que apresentaram taxas de prevalências elevadas de 34\% (MASSAD et al., 1999) e 41\% (GUIMARÃES et al., 2001), respectivamente. Em outras investigações são encontrados valores semelhante a este trabalho (8,7\%): prisão de Manhuaçu-MG 6,3\% (CATALAN-SOARES; ALMEIDA; PROIETTI, 2000) e na Fundaçâo CASA, em dois momentos separados, estimativas entre adolescentes de 6\% (CARVALHO et al., 2003) e 5,9\% (ZANETTA et al., 1999). Mesmo no sexo feminino, a hepatite $C$ entre presas tem importância significativa. Strazza et al. (2007) encontraram taxa de 16,2\% entre mulheres encarceradas em uma penitenciária da Cidade de São Paulo.

Apesar da ausência de dados reais sobre as prevalências de hepatite $B$ e hepatite $C$ no nosso País, pode-se afirmar que as taxas encontradas aqui para esses vírus são superiores a da população geral. A se valer dos 5,94\% para vírus B e 1,42\% para vírus C estimados por Focaccia et al. (1998) no Município de São Paulo, essa pesquisa encontrou valores que estão mais de três vezes acima para o primeiro agente e pouco acima de seis vezes para o segundo. Da análise dos achados nas prisões do Brasil, percebe-se que as prevalências são acentuadamente maiores nas prisões de cidades do Estado de São Paulo, sobretudo em relação à infecção do HCV. Em relação a contaminação por este vírus, excetuando-se algumas populações (renais crônicos, hemofílicos), há intensa associação com os UDIs, especialmente nos indivíduos encarcerados. Esta forma de uso de drogas tem mudado para outros tipos (fumar ou inalar), o que trouxe impacto às incidências e prevalências de doenças de transmissão sanguínea, como demonstrado por Burattini et al. (2005). A migração do UDI para outros modos de uso é decorrente, ao mesmo tempo, do programa de combate a aids que veio trazer noções de segurança à contaminação do HIV, levando 
como conseqüência, atrelado, atenuações dos riscos de infecção do HBV e $\mathrm{HCV}$, principalmente relacionado à transmissão pelo sangue. $\mathrm{O}$ exemplo para isso é o programa de redução de danos que tem como um dos pilares a prática de trocas de agulhas e seringas para os UDIs.

Em prisões e penitenciárias norte americanas, a hepatite B e, mais recentemente, hepatite C são alvos de diversos estudos epidemiológicos. Com uma população carcerária - a maior do mundo - que ultrapassa a casa dos 2,2 milhões de indivíduos, os EUA têm a mais elevada taxa de aprisionamento (acima de 700 por 100.000 habitantes), alcançada em junho de 2006 (SABOL; MINTON; HARRISON, 2007). Nos EUA, a taxa para marcadores de hepatite $B$ nas prisões é 13 a 47\% com portadores crônicos estimados em 1,0 a 3,7\%, sendo este valor duas a seis vezes maior que a prevalência da população geral norte americana (CDC, 2003). A maior parte destes casos é de indivíduos que adquiriram o HBV na comunidade. Porém, há casos de contaminação dentro das próprias dependências da prisão, como relatado pelo CDC (2001), onde um homem preso há mais de dois anos teve hepatite $B$ aguda, tendo como único fator de risco relatado relação sexual desprotegida com colega de cela - que se descobriu ser portador crônico do vírus $B$ na investigação - nos seis meses precedentes à doença. Números de prevalência para infecção prévia ou atual pelo HBV em prisões dos EUA são 32,8\% no Estado da Virgínia (TUCKER et al., 1987) e 43\% no Estado de Massachusetts (BARRY et al., 1990). Números semelhantes a esta pesquisa (19,5\%) foram encontrados com 25,2\% no Estado de Maryland (SOLOMON et al., 2004); 20,5\% no Estado da Geórgia (KHAN et al., 2005); 20,2\% no Estado de Rhode Island (MACALINO et al., 2004a). Em relação ao HCV, Hammett, Harmon e Rhodes (2002) estimaram que sua prevalência fosse de 17 a $25 \%$ no sistema prisional norte americano, no ano de 1997. Neste país diversos trabalhos ilustram esta alta prevalência. Prisões do Estado de Rhode Island tiveram um número de 23,1\% em relação ao HCV (MACALINO et al., 2004a). No Estado da Califórnia, 34,3\% dos encarcerados apresentaram anti-HCV reagente (FOX et al., 2005). Três instituições do Estado do Texas tiveram prevalências que variaram de 27 a 
29,7\% (BAILLARGEON et al., 2003). No Estado de Maryland o valor calculado resultou em 29,7\% (SOLOMON et al., 2004).

Em outras partes do mundo, as prevalências para hepatite $B$ e Hepatite $C$ nas prisões também apresentam índices expressivos. Para o HBV e HCV, as taxas são respectivamente de 6,2\% e 21,8\% em Dublin na República da Irlanda (LONG et al., 2001); 4,4\% e 10\% em Durango no México (ALVARADO-ESQUIVEL et al., 2005); dois levantamentos da Austrália mostram valores de $31 \%$ e $37 \%$ em Nova Gales do Sul (BUTLER et al., 1997) e 33\% e 39\% em Victoria (CROFTS et al., 1995); em pesquisa nacional, a Inglaterra, em oito prisões, relata valores de 8\% e 7\% (WEILD et al., 2000); em outro estudo na Itália, também em oito unidades prisionais, são relatados expressivos valores de $38 \%$ e $52,7 \%$ (BABUDIERI et al., 2005) e em Leiria, Portugal, 40\% e 42\% (PASSADOURO, 2004). Para investigação apenas de hepatite C, em Hamedan no Irã, encontrou-se 30\% (ALIZADEH et al., 2005) e no Canadá, em duas análises, foram registrados 16,6\% em Quebec (POULIN et al., 2007) e 15,9\% em Ontário (CALZAVARA et al., 2007).

O achado de maior prevalência para o HBV ocorre na faixa etária a partir dos 31 anos. Este dado tem semelhança com as notificações do SINAN (BRASIL, 2007a) que apresentou $52,6 \%$ dos casos de hepatite B na população de 20 a 39 anos, seguido pela faixa de 40 a 59 anos com 31,6\%, notificados de 2001 a 2006. Este dado é compatível com o encontrado por Martelli et al. (1990) em Goiânia com 37,5\% dos infectados no grupo de 30 a 39 anos. Em prisões da Inglaterra o predomínio de infectados foi na faixa etária acima de 41 anos (44,4\%) (WEILD, 2000). Na República da Irlanda $32,1 \%$ dos contaminados tinham acima de 30 anos (LONG, 2001). Esta informação de maior prevalência do vírus da hepatite $B$ nos indivíduos acima dos 30 anos também é confirma por outros levantamentos. (BARRY et al.,1990; CHIARAMONTE et al.,1982; CHRISTESEN et al., 2000; HULL et al., 1985). A distribuição pela variável idade tem grande importância no estudo da epidemiologia do HBV, principalmente por refletir aspectos comportamentais de risco ao longo da vida, como atividade sexual 
desprotegida e uso de drogas ilícitas, sobretudo as injetáveis, além de mostrar população vacinada ou não. Na presente pesquisa, a variável idade mostrou associação significante no estudo uni e multivariado. Neste último, o risco de contágio do HBV nos presidiários acima de 30 anos foi acima de três vezes àqueles com idade menor de 30 .

A faixa de idade de 40 a 59 anos corresponde a um pouco mais da metade $(51,7 \%)$ dos casos notificados de hepatite C pelo SINAN (BRASIL, 2007a) no território brasileiro de 2001 a 2006. Este valor aproxima-se do mostrado no presente trabalho com $48,3 \%$ de contaminados na faixa etária acima de 36 anos (14 casos). Dados contrários a este - ou seja, indivíduos jovens à infecção do HCV - foram encontrados por Guimarães et al. (2001), onde ter idade menor que 28 anos era fator de risco ao HCV e Pallás et al. (1999b) que demonstraram presidiários de 26 a 30 anos com maior quantidade de infectados a este vírus (32\%). Já a maioria dos trabalhos apresenta prevalência ao HCV mais elevada no grupo etário a partir - de pelo menos - 30 anos, variando de 22,1 a 58,5\% (ADJEl et al., 2006; CALZAVARA et al., 2007; MACALINO et al., 2004a; MILLER; BI; RYAN, 2006; RUIZ et al., 1999; SOLOMON et al., 2004). A idade acima dos 40 anos está relacionada à infecção pelo HCV pelo maior tempo de exposição ao longo da vida, especialmente nos usuários de drogas ilícitas. Também neste estudo, semelhante ao HBV, a idade foi fator de risco importante para aquisição do HCV na população de encarcerados acima dos 30 anos.

Merece comentário o nível extremamente reduzido do grau de educação da população do estudo. Praticamente $60 \%$ dos envolvidos tinham menos de 6 anos de escolaridade, o que mostra uma dificuldade de acesso à escola ou, mais provavelmente, o abandono precoce. A retirada do individuo da sociedade para a prisão, ou o próprio envolvimento em atividades ilícitas, também podem funcionar como determinantes de um baixo nível de escolaridade. Vale salientar, a presença de investigados que referiram ter dado continuidade aos estudos, ou mesmo concluído o ensino fundamental, dentro da própria instituição penal. Segundo Fonseca et al. (2000), renda, ocupação e nível educacional são importantes indicadores 
das condições de saúde da população. Este último é o de maior valor entre todos, por ser mais fácil de ser obtido e ter grande peso como determinante de saúde. De forma consistente com isso, na presente pesquisa verificou-se maior concentração de positivos ao HBV e HCV nos sentenciados de baixa escolaridade (até 8 anos de estudo), muito embora essa diferença não tenha atingido o limite da significância estatística dos cálculos uni e multivariados. Informações sobre relação do HBV e/ou HCV com nível de escolaridade de presidiários são investigados em pesquisas de soroprevalência. Encontramse resultados equivalentes, aos daqui estimados, em relação a esta variável em prisão do Irã (ALIZADEH, 2005) e do Estado norte americano da Geórgia (KHAN et al., 2005).

Alguns estudos implicam as variáveis "história prévia de encarceramento" e "múltiplos encarceramentos" com importante correlação estatística com infecção pelo HCV (BUTLER et al., 1997; MACALINO et al., 2004b; MALLIORI et al., 1998), resultado da associação com uso de drogas ilícitas, onde os UDIs são mais propensos de serem presos diversas vezes e por longas sentenças. Ainda segundo Macalino et al. (2004b), uma explicação alternativa é o encarceramento ser fator de risco independente para contração da infecção pelo vírus da hepatite C. Durante a prisão, os encarcerados são mais susceptíveis a traumas por brigas, compartilhamento de barbeadores e outras exposições onde possa ocorrer contato sangue a sangue, conduzindo à contaminação pelo HCV. Hull et al. (1985) encontraram associação com tempo total de pena acima de 5 anos e infecção pelo HBV. Tempo de pena cumprido foi fator de risco independente à infecção pelo HCV na Casa de Detenção de São Paulo (acima de 130 meses) (GUIMARÃES et al., 2001) e em Gana (acima de 3 anos) (ADJEI et al., 2007). A presente investigação não encontrou associação das presenças dos vírus da hepatite $\mathrm{B}$ e $\mathrm{C}$ com a variável tempo da pena total nos estudos uni e multivariados. Já em relação ao tempo de pena cumprido não houve associação estatística entre positividade ao HBV, todavia a infecção do HCV teve significância no cálculo univariado, não se confirmando no multivariado. 
Os encarcerados têm risco aumentado à contaminação de DSTs, comparado população geral. Altas taxas de gonorréia, clamídia e sífilis são descritas entre presidiários que praticam sexo sem preservativo com múltiplos (as) parceiros (as) (WEINBAUM; SABIN; SANTIBANEZ, 2005; WOLFE et al., 2001). É consenso que as DSTs elevam a disseminação do HIV, hipótese sugerida pela primeira vez por Piot et al. (1984). Para as hepatite B e hepatite $C$, esta correlação direta com DSTs não é evidente, podendo ocorrer não de forma independente, porém associado com outros fatores de risco, como população de usuários de drogas ilícitas na forma injetável. Como exemplo, Murray et al. (2003) encontraram associação entre história prévia de DSTs e risco aumentado para o HCV em população de infectados que também era UDIs. Para a presente pesquisa, foram feitas inicialmente perguntas a respeito de DSTs ulcerativas e não ulcerativas. Contudo, para fins de análise, foram juntadas em apenas uma variável denominada DST (qualquer tipo) prévia. Nesse novo formato, história prévia de DST não teve relação estatística, na análise univariada, com HBV, porém teve com HCV, que não foi confirmado na regressão logística. A possível explicação para esta não associação seria o baixo número de presos que relataram DST do tipo ulcerativa (mais efetiva a transmissão viral através da lesão ulcerada), dois no grupo do HBV e quatro no do HCV. Outros trabalhos que também investigaram DST e hepatites na prisão, apresentaram resultados compatíveis (ADJEl et al., 2006; ALIZADEH et al., 2005).

Vários relatos mencionam contato sexual entre os encarcerados, dentro das prisões, inclusive associado a uso de drogas injetáveis (GORE; BIRD; HUTCHINSON, 1998). O presente estudo não apontou nada neste sentido, e uma possível explicação pode estar relacionada ao estigma associado ao assunto, fazendo com que as pessoas negassem essa prática. Adicionalmente, há que se considerar que a preferência sexual naquele ambiente poderia ser circunstancial. $O$ indivíduo estaria e não seria homossexual, por uma série de motivos, entre os quais predominaria a coerção. Minkoves (1992) afirma em seu levantamento de hepatite B no Complexo do Carandiru que a pergunta sobre comportamento sexual gerou 
inibição por parte dos presos, não se podendo confiar totalmente nestes dados. Outro fato que justificaria essa ausência é o aprisionamento dos homossexuais (travestis, garotos de programa, etc) na ala do "seguro", onde abriga os que necessitam de isolamento por questões de segurança. Isso poderia ser considerado um viés na resposta desta variável, já que alguma parcela dos que assumem essa condição não tiveram condições de participação. $O$ único recluso que assumiu sua condição homossexual apresentou sorologia reagente para o HCV e, também, para o HIV. Essa quantidade inexpressiva de participantes pode explicar sua não associação estatística com os marcadores do HBV e HCV. Ressalta-se que esta última, não obstante o valor de $p(0,087)$ na análise univariada, não participou do estudo multivariado por apresentar freqüência zero, o que inviabilizou a análise. No entanto, são em maior quantidade os trabalhos relatando presidiários homossexuais com prática dentro dos presídios (ALLRIGHT et al., 2000; CALZAVARA et al., 2007; FOX et al., 2005; LOURENÇO, 1992; MASSAD et al., 1999; PALLÁS et al., 1999a).

Merece destaque o relato de baixo percentual $(20,7 \%)$ de uso de preservativo na visita íntima (69/333). Provavelmente, este achado esteja associado à idéia de irrestrita confiança em relação a uma companheira que supostamente tem somente o próprio presidiário como parceiro. Nessas condições, a utilização da camisinha traria à relação sexual certo caráter de suspeição. Tourinho e Dourado (2002) mostraram que o conhecimento dos modos de transmissão do HIV não foi acompanhado pela prática sexual segura, com 59,5\% dos estudados não usando proteção nas suas relações. No presente estudo, alguns participantes informaram que não utilizavam camisinhas por não serem distribuídas pela instituição, acusação essa rebatida pela direção da penitenciária, que afirma que o fornecimento é constante e sem limite de quantidade. Em conversas informais, os agentes penitenciários relatavam sobre presença de prostitutas em dias de visita na penitenciária que fazem programas sexuais com presos e muitos desses não solicitam preservativos, fato também relatado em prisões da França e Inglaterra (GREEN et al., 2003; ROTILY et al., 1997). Mesmo com a vasta 
maioria dos participantes referindo não usar preservativos em visitas íntimas, não ocorreram associações estatísticas entre as variáveis nas duas análises (uni e multivariada). Uma explicação possível para este fato seria que os expostos ao HBV e ao HCV, em sua maioria, podem ter sido infectados antes do aprisionamento. Em relação ao HCV, uma explicação adicional seria também a baixa eficácia da sua transmissão pela via sexual.

Apesar de não ter sido discriminado o tipo de droga consumida pelas parcerias dos presos, é de se supor que grande parte usava drogas não injetáveis. As análises uni e multivariadas não demonstraram associações estatísticas com relacionamento sexual com usuários de drogas ilícitas. Este achado, também foi observado por Adjei et al. (2006). Pode-se supor que a não associação em relação ao HBV deva-se ao fato de que, nesta população específica, a transmissão estar mais relacionada a outro tipo de exposição. Para o HCV, a explicação poderia ser, como já mencionado, a pouca eficiência de transmissão deste vírus por via sexual. Vale ressaltar, que o número dos presidiários que efetivamente teriam relacionamento sexual com usuárias de drogas ilícitas poderia ser mais elevado que o observado por meio da análise das respostas ao questionário, uma vez que o uso dessas substâncias por parcerias eventuais poderia passar despercebido aos seus contactantes, o que seria ainda mais relevante em relação à transmissão do HBV.

O consumo prévio de drogas ilícitas não injetáveis é algo marcante nesta pesquisa, como já comentado acima. Há vínculo consistente entre esta população e o uso destas substâncias, principalmente porque o seu uso é considerado delito criminal em nosso país. Nesta forma de utilização de drogas ilícitas, o risco para infecções por hepatite, especialmente do tipo C, pode estar associado ao uso intranasal. Se o instrumento utilizado para a aspiração da droga (geralmente um canudo) contiver sangue, este pode transmitir o vírus através da mucosa nasal lesada para a corrente sanguínea (CONRY-CANTILENA et al., 1996). Outra forma de exposição dos usuários de drogas à hepatite é pela via sexual. Estes indivíduos tendem a ter múltiplos (as) parceiros (as) sexuais, procuram mais por profissionais do 
sexo, usam menos preservativos e têm mais DSTs (ROSS et al., 2003; SHARMA; AGGARVAL; DUBEY, 2002;). Diferentemente destes achados, Massad et al. (1999) afirmam que a influência do abuso de drogas na sexualidade é negativa, levando a impotência e diminuição da libido, tendo como conseqüência a não mais procura de parceiros para sexo. $\mathrm{Na}$ análise univariada, não ocorreu associação com HBV, porém houve uma associação bastante significativa para o HCV. No entanto, esta associação não pôde ser analisada por regressão logística, já que apresentou freqüência zero.

A investigação sobre drogas injetáveis se baseou em seu uso em algum momento da vida, no passado e/ou no presente. $O$ fato de nenhum participante ter relatado essa prática no presente levanta alguns questionamentos sobre possibilidade de viés de resposta. A negativa de uso no interior do presídio pode, primeiramente, ser em virtude do estigma associado a esse comportamento - reprovado pelo senso comum e punido criminalmente - e, em seguida, o temor por represálias ao assumir uma conduta ilegal. Soma-se a isso, o fato da aplicação do questionário ter sido feita em ambiente não totalmente confidencial, induzindo o recluso a respostas falsamente negativas. As exposições ao HBV e $\mathrm{HCV}$ foram demasiadamente maiores nos presos que admitiram uso passado de drogas injetáveis e os que assumiram o compartilhamento de agulhas mostrando forte associação estatística para ambas as variáveis $(p=0,000)$ no estudo univariado. Quando há o controle das outras variáveis na regressão logística, o HBV confirma essa associação, com chance de quase três vezes ä sua infecção. O uso de drogas injetáveis e compartilhamento passado de agulhas apresentaram ao cálculo multivariado uma chance acima de quatro vezes e de quase doze vezes, respectivamente, à infecção do HCV. Estas variáveis funcionaram como os fatores que mais intensamente se mostraram capazes de predizer de modo independente a positividade a este vírus. Estes resultados estão de acordos com a literatura que demonstra a infecção do HCV ser adquirida mais rapidamente, depois da iniciação às drogas injetáveis, do que nas contaminações do HBV ou HIV (WEINBAUM; SABIN; SANTIBANEZ, 2005). Esta vigorosa relação entre encarcerados que 
foram ou são UDIs e infecção pelos vírus da hepatite B e, em especial, hepatite $C$ se confirma em diversas pesquisas (ALLWRIGHT et al., 2000; ANDA et al., 1985; CHAMPION et al., 2004; DECKER et al., 1984; HULL et al., 1985; LONG et al., 2001; MALLIORI et al., 1998; MINKOVES, 1992; POULIN et al., 2007; WEILD et al., 2000)

Transfusão sanguínea não se mostrou estatisticamente associada à exposição pelo HBV nem HCV, não obstante as prevalências tenham sido mais elevadas nos que relataram tal história. Embora a transfusão seja a mais eficiente forma de transmissão de ambos os vírus, seus riscos, atualmente, são incomuns, como conseqüência dos procedimentos de triagem sorológica realizados nos bancos de sangue. Fox et al. (2005) encontraram associação entre transfusão sanguínea e HCV nos presidiários não UDIs. No entanto, a maioria dos trabalhos não a encontrou (ALIZADEH et al., 2005; MARTELLI et al., 1990; MURRAY et al., 2003).

No relato de hepatite no passado foi considerada a alegação do presidiário ter sido acometido pela doença em qualquer fase anterior da sua vida, não precisando o seu momento exato. Já na averiguação sobre icterícia, pode ter havido dificuldade no entendimento exato do termo, já que a palavra "tiriça", dentro do presídio, é utilizada para designar "coceira". De qualquer forma, houve números bastante aproximados (27 e 24), entre as duas variáveis, de participantes que as relataram. Vale lembrar que o diagnóstico de hepatite $\mathrm{B}$ e/ou hepatite $\mathrm{C}$ ocorre muitas vezes casualmente (doação de sangue, busca espontânea de seu status sorológico) ou quando se instala quadro agudo, cuja manifestação clínica de maior destaque é a icterícia. Hepatite aguda ictérica pelo vírus $\mathrm{B}$ e, principalmente, vírus $\mathrm{C}$ incide em pequena quantidade de pessoas, diferentemente do HAV que apresenta tal quadro em mais da metade dos casos. Por conta disso, podese deduzir que estes $8,1 \%$ (27/333) que relataram hepatite prévia, podem ter tido como etiologia o vírus da hepatite $A$. Isto poderia explicar a não associação do HBV com o antecedente de hepatite na análise univariada e pela regressão logística. Todavia, para o HCV, houve significância estatística no teste univariado e, ainda, foi capaz de predizer de forma independente a 
presença desse vírus no multivariado. Este achado é compatível com os resultados de penitenciária em Durango, México (ALVARADO-ESQUIVEL et al., 2005). Antecedente de icterícia não se mostrou associado à infecção do HBV e HCV, tendo como explicação a dificuldade de entendimento do significado da palavra, apesar das tentativas de esclarecimento.

Para a variável tatuagem, perguntou-se sobre sua presença, ou não, independente ter sido feita na prisão ou fora desta. Tatuagem tem sido descrito como um fator de risco importante para aquisição de hepatite B e hepatite $\mathrm{C}$ como de outras doenças de contato com sangue, especialmente, na população dos encarcerados. Esse risco se eleva quando a tatuagem é realizada dentro da própria instituição penal, já que envolve utilização de aparelhos e objetos sem o mínimo de condições higiênicas, que pode levar a transmissão de hepatite C como já foi relatado na literatura (TSANG; HOROWITZ; VUGIA, 2001). Algumas pesquisas comparam presidiários com tatuagens feitas fora e dentro do sistema prisional e mostram que estes apresentam risco bem mais incrementado à contaminação do HBV e HCV do que aqueles (HELLARD; AITKEN; HOCKING, 2007; HELLARD; HOCKING; CROFTS, 2004; SAMUEL et al., 2005). Na presente investigação, não houve relação entre HBV e tatuagem, fato também apontado por Anda et al. (1985) e Hull et al. (1985). Para a hepatite C, o resultado da análise univariada ficou próximo ao limite da significância e, com o controle das variáveis de confusão, a presença de tatuagem se associou com um risco acima de três vezes de infecção por este vírus.

Co-infecção do HIV com HBV ou HCV apresenta descrições de prevalências predominantemente elevadas, variando de acordo com a via de exposição (RODRÍGUEZ-MÉNDEZ et al., 2003; TREITINGER et al., 2000). As relações HBV-HCV, HIV-HCV e HIV-HBV apresentam significância estatística (esta última no seu limite), mostrando afinidades nas suas vias de contaminação. Seis presidiários com sorologias reagentes ao HIV-HCV, referiam também ser UDIs. Desses, cinco compartilhavam agulhas. Também, seis indivíduos com HBV-HCV eram UDIs e quatro 
compartilhavam. De cinco co-infectados com HBV-HCV-HIV, quatro relataram ser UDIs.

\subsection{Considerações Finais}

Planos de prevenção às hepatites B e C têm ficado agregados ao Programa de DST/Aids, no nosso pais, sem uma abordagem específica. Desde o início da epidemia do HIV, as pessoas confinadas têm sido objeto de grande preocupação por parte dos programas de controle, uma vez que reúnem riscos comportamentais e ambientais que as conduzem à elevada probabilidade de infecção. As prisões brasileiras sintetizam de modo eloqüente esta situação. Atrelada a essa situação, a precária prevenção das hepatites virais, dentro das prisões, tem se aproveitado do trabalho de combate à contaminação do HIV, já que as fontes de aquisição são, basicamente, as mesmas. A detecção dos portadores do HBV e HCV é muito débil, visto que não são oferecidos de rotina aos presos testes para diagnóstico no inicio do aprisionamento, como ocorre com o HIV. Números elevados de prevalência do HBV e HCV nos encarcerados surgiram desde o início da década de 1990, mas até o momento não existe uma contabilização total da realidade do País. A verdadeira situação é desconhecida, em parte pela pouca priorização conferida a estudos epidemiológicos entre presidiários, e em parte porque grande parte dos presos se concentra em instituições prisionais menores do que as penitenciárias, como cadeias públicas, delegacias de policia (DPS) e centros de detenções provisórias (CDPs). Estes estabelecimentos, ao invés de serem usadas para detenção de suspeitos logo após sua prisão, e por um curto espaço de tempo, mantêm detentos por longos períodos, até mesmo anos.

No entanto, os escassos dados disponíveis apontam para o fato de que as hepatites virais, especialmente a causada pelo vírus $C$, no sistema penal estão vinculadas à origem socioeconômica dos detentos, sua baixa escolaridade, pela freqüência de práticas de risco representadas pelo uso de drogas e múltiplas relações sexuais não protegidas. A estes determinantes 
sociais, somam-se as condições institucionais desfavoráveis ao desenvolvimento de programas educativos.

A carência de serviços de saúde estruturados é notória, mesmo em prisões previamente definidas com estes dispositivos. As atividades de prevenção e assistência necessitam de incremento, sobretudo no que se refere a profissionais capacitados para executá-las. Além da falta de recursos, esta situação é fruto de reduzido número de programas educacionais para a saúde e falta de articulação com o Sistema Único de Saúde (SUS). Mesmo assim, algumas instituições, como a Penitenciária de Ribeirão Preto e outras, têm superado barreiras e procurado fazer frente a estes obstáculos.

A penitenciária em estudo tem um serviço de saúde razoável, com boa disponibilidade de materiais básicos. Apresenta, no entanto, falta de recursos humanos em diversas (médico, enfermeiro, farmacêutico, auxiliar de enfermagem, e outros). Dessa forma, as atividades de assistência e prevenção são limitadas e não contínuas.

De forma geral, os presidiários têm ciência dos mecanismos de transmissão do HIV, porém o conhecimento é reduzido para os vírus das hepatites. Dessa forma, faz-se necessário o desenvolvimento e manutenção de atividades agressivas com vistas à educação continuada e o aconselhamento. Esta última atividade, sem dúvida, reúne um enorme potencial de produzir impactos positivos na luta contra as infecções pelo HBV, HCV e HIV, uma vez que estabelece uma relação de confiança orientada para a transmissão de conteúdos informativos, mais facilmente captados e incorporados pelos presidiários. A possibilidade de realizá-lo também em grupos abre a possibilidade de troca de experiências e informações, enriquecendo substancialmente o processo.

Finalmente, há clara necessidade da continuidade de estudos epidemiológicos que forneçam informações atualizadas sobre o estado de saúde dos presidiários. A grande marginalização desse segmento populacional se reflete na pouca priorização a ele concedida por parte de pesquisadores e de serviços de saúde. 


\section{CONCLUSÕES}

O presente estudo demonstrou que a infecção pelo HBV e pelo HCV entre os presidiários da Penitenciária de Ribeirão Preto está associada às seguintes covariáveis:

\section{HBV}

- $\quad$ Idade acima de 30 anos;

- $\quad$ Passado de drogas injetáveis;

\section{HCV}

- $\quad$ Idade acima de 30 anos;

- $\quad$ Antecedentes de hepatite;

- Tatuagem;

- $\quad$ Passado de drogas injetáveis;

- $\quad$ Passado de compartilhamento de agulhas;

Estes achados atestam a relevância do problema em nosso meio e apontam para importância de ações educativas no controle da disseminação destes vírus nesta comunidade. 


\section{REFERÊNCIAS BIBLIOGRÁFICAS}

- Acedo A, Campos A, Bauzá J, Ayala C, Jover M, Herrero L, Cañigral G, Tascón A. HIV infection, hepatitis and syphilis in spanish prisons. Lancet 1989;22:226.

- Adjei AA, Armah HB, Gbagbo F, Ampofo WK, Quaye IKE, Hesse IFA, Mensah $G$. Prevalence of human immunodeficiency virus, hepatitis $B$ virus, hepatitis $\mathrm{C}$ virus and syphilis among prison inmates and officers at Nsawam and Accra, Ghana. J Med Microbiol 2006;55:593-7.

- Alizadeh AH, Alavian SM, Jafari k, Yazdi N. Prevalence of hepatitis C virus infection and its related risk factors in drug abuser prisoners in Hamedan--Iran. World J Gastroenterol 2005;11:4085-9.

- Allright S, Bradley F, Long J, Barry J, Thornton L, Parry J V. Prevalence of antibodies to hepatitis B, hepatitis $C$ and HIV and risk factors in Irish prisoners: results of a national cross sectional survey. BMJ 2000;321(8):78-82.

- Alter HJ, Purcell RH, ShiH JW, Meldolder JC, Houghton M, Choo QL, Kuo G. Detection of antibody to hepatitis C virus in prospectively followed transfusion recipients with acute and chronic non- $A$, non-B hepatitis. N Engl J Med 1989;321:1494-1500.

- Alter HJ. Discovery of non-A, non-B hepatitis and identification of its etiology. Am J Med 1999;107(suppl. 2):16S-20S.

- Alter MJ. Epidemiology of hepatitis B in Europe and worldwide. J Hepatol 2003a;39:S64-S69.

- Alter MJ. Epidemiology and prevention of hepatitis B. Semin Liver Dis 2003b;23:39-46. 
- Alter MJ. Epidemiology of hepatitis C. Hepatology 1997;26(issue S3):62S-65S.

- Alter MJ, Margolis HS, The emergence of hepatitis B virus as a sexually transmitted disease. Med Clin N Am 1990;74:1529-41.

- Alvarado-Esquivel C, Sablon E, Martinez-Garcia S, Estrada-Martinez S. Hepatitis virus and HIV infections in inmates of a state correctional facility in Mexico. Epidemiol Infect 2005;133:679-85.

- Anda RF, Perlman SB, D'Alessio DJ, Davis JP, Dodson VN. Hepatitis $B$ in Wisconsin male prisoners: considerations for serologic screening and vaccination. Am J Public Health 1985;75:1182-5.

- Azevedo RA, Silva AE, Ferraz ML, Marcopito LF, Baruzzi RG. Prevalência dos marcadores sorológicos dos vírus da hepatite $B$ e $D$ em crianças da tribo Caiabi e Txucarramãe do Parque Indígena do Xingu, Brasil Central. Rev Soc Bras Med Trop 1996;29:431-9.

- Bader T. Hepatitis B carriers in the prison population. N Engl J Med 1983;308:281.

- Babudieri S, Longo B, Sarmati I, Starnini G, Dori L, Suligoi B, Carbonara S, Monarca R, Quercia G, Florenzano G, Novati S, Sardu A, lovinella V, Casti A, Romano A, Uccella I, Maida I, Brunetti B, Mura MS, Andreoni M, Rezza G. Correlates of HIV, HBV, and HCV infections in a prison inmate population: results from a multicentre study in Italy. J Med Virol 2005;76:311-7.

- Baillargeon J, Wu H, Kelley MJ, Grady J, Linthicum L, Dunn K. Hepatitis $C$ seroprevalence among newly incarcerated inmates in the Texas correctional system. Public Health 2003;117:43-8.

- Barry MA, Gleavy D, Herd K, Schwingl PJ, Werner BG. Prevalence of markers for hepatitis $B$ and hepatitis $D$ in a municipal house of correction. Am J Public Health 1990;80:471-3.

- Beasley RP. Hepatitis B virus. The major etiology of hepatocellular carcinoma. Cancer 1988;61:1942-1956. 
- Bensabath G, Leão RN. Epidemiologia na Amazônia Brasileira. In: Focaccia R, editor. Tratado de hepatites virais. São Paulo: Editora Atheneu; 2003. p. 11-26.

- Black FL, Pandey JP, Capper RA. Hepatitis B epidemiology and its relation to immunogenetic traits in south american indians. Am $\mathbf{J}$ Epidemiol 1986;123:336-43.

- Blajchman MA, Bull SB, Feinman SV. Post-transfusion hepatitis: impact of non-A, non-B hepatitis surrogates tests. Lancet 1995;345:21-5.

- Blumberg BS, Alter HJ, Visnich S. A "new" antigen in leukemic serum. JAMA 1965;191:541-6.

- Bond WW, Favero MS, Petersen NJ, Gravelle CR, Ebert JW, Maynard JE. Survival of hepatitis B virus after drying and storage for one week [Letter]. Lancet 1981;1:550-1.

- Boutwell AE, Allen SA, Rich JD. Opportunities to address the hepatitis C epidemic in the correctional setting. Clin Infect Dis 2005;40(suppl 5):S367-S371.

- Brasil. Ministério da Saúde. Secretaria de Vigilância em Saúde. Sistema de informação de agravos de notificação - SINAN. 2007a. Disponível em http://dtr2004.saude.gov.br/sinanweb/. Acessado em 11/11/2007.

- _ _ Ministério da Saúde. Secretaria de Vigilância em Saúde. Sistema de informação de agravos de notificação - SINAN. Vigilância Epidemiológica. Situação das doenças transmissíveis no Brasil. 2004 Ago. Disponível em http://portal.saude.gov.br/portal/saude/visualizar texto.cfm?idtxt=2192 o Acessado em 11/11/2007.

- _ Ministério da Justiça. Secretaria Nacional de Justiça. Departamento Penitenciário Nacional. Sistema Integrado de Informações Penitenciárias - InfoPen. Jun 2007b. Disponível em: www.mi.gov.br/depen/data/Pages/MJD574E9CEITEMIDC37B2AE94C 6840068B1624D28407509CPTBRIE.htm Acessado em 11/11/2007. 
- Brewer T, Vlahov D, Taylor E, Hall H, Munoz A, Polk B. Transmission of HIV-1 within a statewide prison system. AIDS 1988;2:363-7.

- Bronowicki JP, Venard V, Botté C, Monhoven N, Gastin I, Choné L, Hudziak H, Rhin B, Delanoé C, Lefaou A, Bigard MA, Gaucher P. Patient-to-patient transmission of hepatitis $\mathrm{C}$ virus during colonoscopy. N Engl J Med 1997;337:237-40.

- Burattini M, Strazza L, Paoliello AA, de Carvalho HB, de Azevedo RS, Coutinho FA, Massad E. The change from intravenous to crack cocaine and its impact on reducing HIV incidence in Brazilian prison. Int J STD AIDS 2005;16:836-7.

- Butler TG, Dolan KA, Ferson MJ, McGuinness LM, Brown PR, Robertson PW. Hepatitis B and C in New South Wales prisons: prevalence and risk factors. Med J Aust 1997;166:127-30.

- Butler TG, Spencer J, Cui J, Vickery K, Zou J, Kaldor J. Seroprevalence of markers for hepatitis B, C and $G$ in male and female prisoners-NSW, 1996. Aust N Z J Public Health 1999;23:377.

- Callender ME, White YS, Williams R. Hepatitis B virus infection in medical and health care personnel. Br Med J 1982;284:324-6.

- Calzavara L, Ramuscak N, Burchell AN, Swantee, C, Myers T, Ford P, Fearon M, Raymond S. Prevalence of HIV and hepatitis C vírus infections among inmates of Ontario remand facilities. CMAJ 2007;177:257-61.

- Carvalho HB, Seibel SD, Burattini MN, Massad E, Reingold A. Vulnerabilidade às infecções pelo HIV, hepatite B e C e sífilis entre adolescentes infratores institucionalizados na Cidade de São Paulo, Brasil. J Bras Doenças Sex Transm 2003;15:41-5.

- Catalan-Soares B, Almeida R, Proietti A. Prevalence of HIV-1/2, HTLV-I/II, hepatitis B virus (HBV), hepatitis C virus (HCV), Treponema pallidum and Trypanosoma cruzi among prison inmates at Manhuaçu, Minas Gerais State, Brazil. Rev Soc Bras Med Trop 2000;33(1):2730. 
- Cavalheiro NP. Hepatite C: transmissão entre casais. 2004, 111p. Dissertação (Doutorado) - Faculdade de Medicina, Universidade de São Paulo, São Paulo, 2004.

- Centers for Diseases Control and Prevention. Viral hepatitis and injection drug users. Idu/Hiv/Prevention. September,2002. Disponível em: www.cdc.gov/idu/hepatitis/viral hep drug use.pdf Acessado em 11/11/2007.

- Centers for Diseases Control and Prevention. Hepatitis B outbreak in a state correctional facility, 2000. Morbid Mortal Weekly Rep. 2001;50:529-32.

- Centers for Diseases Control and Prevention. Prevention and control of infections with hepatitis virus in correctional settings. Morbid Mortal Weekly Rep. 2003;52(RR-01):1-33.

- Centers for Diseases Control and Prevention. Transmission of hepatitis B virus among persons undergoing blood glucose monitoring in long-term-care facilities. Morbid Mortal Weekly Rep 2005;54:2203.

- Champion JK, Taylor A, Hutchinson S, Cameron S, McMenamin J, Mitchell A, Golberg D. Incidence of hepatitis C virus infection and associated risk factors among Scottish prison inmates: A cohort study. Am J Epidemiol 2004;159:514-9.

- Chauduri AKR, Follet EA. Hepatitis B virus infection in medical and health care personnel [Letter]. Br Med J 1982;284:1408.

- Chiaramonte M, Trivello R, Renzulli G, Zampieri L, Fanecco A, Naccarato R. Hepatitis B virus infection in prisons. A seroepidemiological survey in prisoners and attending staff. J Hyg (Lond) 1982;89:53-8.

- Choo QL, Kuo G, Weiner AJ, Overby LR, Bradley DW, Houghton M. Isolation of a cDNA clone derived from a blood-borne non-A, non-B viral hepatitis genome. Science 1989;244:359. 
- Christensen PB, Krarup HB, Niesters HGM, Norder H, Georgsen J. Prevalence and incidence of bloodborne viral infections among Danish prisoners. Eur J Epidemiol 2000;16:1043-9.

- Coimbra JC, Santos RV, Yoshida CF, Baptista ML, Flowers NM, do Valle AC. Hepatitis B epidemiology and cultural practices im Amerindian populations of Amazonia: The Tupi-Monde and the Xavante from Brazil. Soc Sci Med 1996;42:1735-43.

- Conry-Cantilena C, VanRaden M, Gibble J, Melpolder J, Shakil AO, Viladomiu L, Cheung L, DiBisceglie A, Hoofnagle J, Shih JW, Kaslow R, Ness P, Alter HJ. Routes of infection, viremia, and liver disease in blood donors found to have hepatitis C virus infection. Routes of infection, viremia, and liver disease in blood donors found to have hepatitis C virus infection. N Engl J Med 1996;334:1691-6.

- Crofts N, Hopper JL, Bowden DS, Breschkin AM, Milner R, Locarnini SA. Hepatitis $C$ virus infection among a cohort of Victorian injecting drug users. Med J Aust 1993;159:237-41.

- Crofts N, Stewart T, Hearne P, Ping XY, Breschkin AM, Locarnini SA. Spread of bloodborne viruses among Australian prison entrants. BMJ 1995;310:285-8.

- Custer B, Sullivan SD, Hazlet TK, lloeje U, Veenstra DL, Kowdley KV. Global epidemiology of hepatitis B virus. J Clin Gastroenterol 2004;38(suppl. 3):S158S-S168.

- Darani M, Gerber M. Hepatitis B antigen in vaginal secretions. Lancet 1974;2:1008.

- Dean AG, Dean JA, Coulombir D, Brendel KA, Smith DC, Burton AH, et al. Epi Info, version 6: a word processing database and statistics programs for epidemiology on microcomputers. Atlanta, Georgia: Centers for Disease Control and Prevention;1994.

- Decker MD, Vaughn WK, Brodie JS, Hutcheson RH, Schaffner W. Seroepidemiology of hepatitis B in Tennessee prisoners. J Infect Dis 1984;150:450-9. 
- Denes AE, Smith JL, Maynard JE, Doto IL, Berquist KR, Finkel AJ. Hepatitis $B$ infection in physicians: results of a nationwide seroepidemiologic survey. JAMA 1978;239:210-2.

- Donahue JG, Munoz A, Ness PM, Brown DE, Yawn DH, McAllister HA, Reitz BA, Nelson KE. The declining risk of post-transfusion hepatitis C virus infection. N Engl J Med 1992;327:369-73.

- Esteban JI, Gómez J, Martell M, Cabot B, Quer J., Camps J, González A, Otero T, Moya A, Esteban R, Guardia J. Transmission of hepatitis C virus by a cardiac surgeon. N Engl J Med 1996;334:555-60.

- Fairley CK, Leslie DE, Nicholson S, Gust ID. Epidemiology and hepatits C vírus in Victoria. Med J Aust 1990;153:247-9.

- Fay $\mathrm{OH}$. Hepatitis B in Latin America: epidemiological patterns and eradication strategy. The Latin American Regional Study Group. Vaccine 1990;8(suppl. 1):S100-S106.

- Feinstone SM, Kapikian AZ, Purcell RH, Alter HJ, Holland PV. Transfusion-associated hepatitis not due to viral hepatitis A or B. N Engl J Med 1975;292-767-70.

- Fergusson DM, Swain-Campbell NR, Horwood LJ. Arrests and convictions for cannabis related offences in a New Zealand birth cohort. Drug Alcohol Depend 2003;70:53-63.

- Ferrari JO, Ferreira MU, Tanaka A, Mizokami M. The seroprevalence of hepatitis $B$ and $C$ in an Amerindian population in the southwestern Brazilian Amazon. Rev Soc Bras Med Trop 1999;32:299-302.

- Focaccia R, Baraldo DC, Souza FV. Epidemiologia. In: Focaccia R, editor. Tratado de hepatites virais. São Paulo: Editora Atheneu; 2003. p. 221-9.

- Focaccia R, da Conceição OJ, Sette HJr, Sabino E, Bassit L, Nitrini DR, Lomar AV, Lourenço R, Vieira de Souza F, Kiffer CR, Santos EB, Gonzales MP, Saez-Alquezar A, Riscal JR, Fischer D. Estimated prevalence of viral hepatitis in the general population of the municipality of São Paulo, measured by a serologic survey of a 
stratified, randomized and residence-based population. Braz J Infect Dis 1998;2:269-84.

- Fonseca JCF. Relatório do grupo de estudo da Sociedade Brasileira de Hepatologia. Epidemiologia da infecção pelo vírus da hepatite C no Brasil. GED 1999;18(Suppl. 1):S3-S8.

- Fonseca MG, Bastos FI, Derriço M, Andrade CLT, Travassos C, Szwarcwald CL. AIDS e grau de escolaridade no Brasil: evolução temporal de 1986 a 1996. Cad Saúde Pública 2000;16(Suppl.1):S77S87.

- Fox RK, Currie SL, Evans J, Wright TL, Tobler L, Phelps B, Busch MP, Page-Shafer KA. Hepatitis $C$ virus infection among prisoners in the California state correctional system. Clin Infect Dis 2005;41:177-86.

- Francis DP, Favero MS, Maynard JE. Transmission of hepatitis B virus. Semin Liver Dis 1981;1:27-32

- Franco VS, Guimarães RX, Franco LJ, Baruzzi RG, Novo NF. Marcadores sorológicos da hepatite viral B e alfa 1 antitripsina em índios da tribo Mekranhotire. Rev Paul Med 1985;103:223-7.

- Frank C, Mohamed MK, Strickland GT, Lavanchy D, Arthur RR, Maqder LS, El Khoby T, Abdel-Wahab Y, Aly Ohn ES, Anwar W, Sallam I. The role of parenteral antischistosomal therapy in the spread of hepatitis C virus in Egypt. Lancet 2000;355:887-91.

- Freitas J. Perspectivas históricas. In: Cotter J. Hepatites Víricas. Guimarães: Núcleo de Gastroenterologia dos Hospitais Distritais; 2003. p. $15-41$.

- Gayotto LC, Quarentei AA, Cabral GL. Soroepidemiologia das hepatites A e B nas regiões dos rios Biá e Alto Juruá, Amazônia Ocidental. GED 1984;3:106-12.

- Giles JP, McCollum RW, Berndstrom LW Jr, Krugman S. Viral hepatitis: relationship of Australia-SH antigen to the Willowbrook MS-2 strain. N Engl J Med 1969;281:119-22.

- Gore SM, Bird AG, Hutchinson SJ. Injector-inmates and anal sex with another man in prison. Int J STD AIDS 1998;9:781. 
- Graf JP, Moeschlin P. Risk to contacts of a medical practitioner carryng HBsAg. N Engl J Med 1975;293:197.

- Green J, Heuston J, Whiteley C, Strang J. Heterosexual activity of male prisoners in England and Wales. Int J STD AIDS 2003;14:24852.

- Guimarães T, Granato CF, Varella D, Ferraz ML, Castelo A, Kallas EG. High prevalence of hepatitis $C$ infection in a brazilian prison: identification of risk factors for infection. Braz J Infect Dis 2001;5:1118.

- Halfon P, Riflet H, Renou C, Quentin Y, Cacoub P. Molecular evidence of male-to-female sexual transmission of hepatitis $C$ virus after vaginal e anal intercourse. J Clin Microbiol 2001;39:1204-6.

- Hall W, Solowij N. Adverse effects of cannabis. Lancet 1998;352:1611-6.

- Hammett TM, Harmon MP, Rhodes W. The burden of infectious disease among inmates of and releases from US correctional facilities, 1997. Am J Public Health 2002;92:1789-94.

- Hauri AM, Armstrong GL, Hutin YJ. The global burden of disease attributable to contaminated injections given in health care settings. Int J STD AIDS 2004;15:7-16.

- Heathcote J, Gateau P, Sherlock S. Role of hepatitis B antigen carriers in non-parenteral transmission of hepatitis B virus. Lancet 1974;2:370-1.

- Heathcote J, Cameron CH, Dane DS. Hepatitis B antigen in saliva and semen. Lancet 1974;1:71-3.

- Hellard ME, Aitken CK, Hocking JS. Tattooing in prisons--not such a pretty picture. Am J Infect Control 2007;35:477-80.

- Hellard ME, Hocking JS, Crofts N. The prevalence and the risk behaviours associated with the transmission of hepatitis $C$ virus in Australian correctional facilities. Epidemiol Infect 2004;132:409-15. 
- Henderson DK. Mananging occupational risks for hepatitis C transmission in the health care setting. Clin Microbiol Rev 2003;16:546-68.

- Hersch T, Melnick JI, Goyal RK, Hollinger MD. Nonparenteral transmission of viral hepatitis type B (Australia antigen-associated serum hepatitis). N Engl J Med 1971;285:1363-4.

- Hindman SH, Gravelle CR, Murphy BL, Braddley DW, Budge WR, Maynard JE. "e" antigen, Dane particles and serum DNA polymerase activity in HBsAg carriers. Ann Intern Med 1976;85:458-60.

- Hok KA, Nieman R, Lackey JO, Cabasso VJ. Australia antigen in a closed adult population monitored for serum glutamic oxalacetic transaminase. Appl Microbiol 1970;20:6-10.

- Holsen DS, Harthug S, Myrmel H. Prevalence of antibodies to hepatitis $C$ vírus and associations with intravenous drug abuse and tattooing in a national prison in Norway. Eur $\mathbf{J}$ Clin Microbiol Infect Dis 1993;12:673-6.

- Horne JA, Clements AJ, Drennan P, Stein K, Cramp ME. Screening for hepatitis $C$ virus in the Dartmoor prison population: an observational study. J Public Health (Oxf) 2004;26:372-5.

- Hosmer JR, Lemeshow D. Applied Logistic Regression, 2ed., New York: John Willey \& Sons, 2000.

- Houghton M, Weiner AJ, Kuo G, Choo QL. Molecular biology of the hepatitis C viruses: implications for diagnosis, devolopment and control. 1991 Hepatology 14: 381-8.

- Hull HF, Lyons LH, Mann JM, Hadler SC, Steece R, Skeels MR. Incidence of hepatitis B in the penitentiary of New Mexico. Am J Public Health 1985;75:1213-4.

- Jabur A, Baldy JLS, Quesada RMB. AIDS, hepatite B e sífilis: prevalência da infecção em 158 presidiários da cadeia pública de Londrina. Rev Soc Bras Med Trop 1991;24(2suppl.II):169. [Presented at XXVII Congresso da Sociedade Brasileira de Medicina Tropical; 1991. Feb 24-28; Uberaba]. 
- Johnson IL and Hepatits B Outbreak Investigation Team. An outbreak of hepatitis B associated with reusable subdermal electroencephalogram electrodes. CMAJ 2000;162:1127-31.

- Kandel DB. Does marijuana use of other drugs? JAMA 2003;289:4823.

- Kao JH, Hwang YT, Chen PJ, Yang PM, Lai MY, Wang TH, Chen DS. Transmission of hepatitis $C$ virus between spouses: the important role of exposure duration. Am J Gastroenterol 1996;91:2087-90.

- Kent GB, Brondum J, Keenlyside RA, LaFazia LM, Scott HD. A large outbreak of acupuncture-associated hepatitis B. Am J Epidemiol 1988;127:591-8.

- Kew M, François G, Lavanchy D, Margolis H, Van Damme P, Grob P, Hallauer J, Shouval D, Leroux-Roels G, Meheus A. Prevention of hepatitis C virus infection. J Viral Hepat 2004;11:198-205.

- Khan AJ, Simard EP, Bower WA, Wurtzel HL, Khristova M, Wagner KD, Arnold KE, Nainan OV, LaMarre M, Bell BP. Ongoing transmission of hepatitis $B$ virus infection among inmates at a state correctional facility. Am J Public Health 2005;95:1793-9.

- Kibby T, Devine J, Love C. Prevalence of hepatitis B among men admitted to a federal prison. N Engl J Med 1982;306:175.

- Kiffer CR, Viana GB, Cheinquer H. Epidemiologia. In: Focaccia R, editor. Tratado de hepatites virais. São Paulo: Editora Atheneu; 2003. p. 127-32.

- Kiyosawa K, Sodeyama T, Tanaka E, Nakano Y, Furuta S, Nishioka K, Purcell RH, Alter HJ. Hepatitis $\mathrm{C}$ in hospital employees with needlestick injuries. Ann Intern Med 1991;115:367-9.

- Kliman A. Australia antigen in volunteers and paid blood donors. N Engl J Med 1971;284:109.

- Koplan JP, Walker JA, Bryan JA. Prevalence of hepatitis B surface antigen and antibody at a state prison in Kansas. J Infect Dis 1978;137:505-6. 
- Krotoski WA. Hepatitis in prisoner blood donors. N Engl J Med 1972;286:159.

- Krugman S, Giles JP, Hammond J. Infectious hepatitis. Evidence for two distinctive clinical, epidemiological, and immunological types of infection. JAMA 1967;200:365-73.

- Kumar RM, Shahul S. Role of breast-feeding in transmission of hepatitis C virus to infants of HCV-infected mothers. J Hepatol 1998;29:191-7.

- Lai CL, Ratziu V, Yuen MF, Poynard T. Viral hepatitis B. Lancet 2003;362:2089-94.

- Lam JP, McOmish F, Burns SM, Yap PL, Mok JY, Simmonds P. Infrequent vertical transmission of hepatitis $C$ virus. J Infect Dis 1993;167:572-6.

- Lauer GM, Walker BD. Hepatitis C virus infection. N Engl J Med 2001;345:41-52.

- Lee C, Gong Y, Brok J, Boxall EH, Gluud C. Effect of hepatitis B immunization in newborn infants of mothers positive for hepatitis $B$ surface antigen: systematic review and meta-analysis. BMJ 2006;332:328-36.

- Lee WM. Hepatitis B virus infection. N Engl J Med 1997;337:1733-45.

- Leon P, Venegas E, Bengoechea L, Rojas E, López JA, Elola C, Echevarría JM. Prevalencia de las infecciones por virus de las hepatitis B, C, D y E in Bolivia. Rev Panam Salud Publica 1999;5:144-51.

- Levin ML, Maddrey CW, Wands JR. Hepatitis B transmission by dentists JAMA 1974;228:1139-40.

- Lewis DK, Watters JK, Case P. The prevalence of high-risk sexual behavior in male intravenous drug users with steady female partners. Am J Public Health 1990;80:465-6. 
- Lewis TL, Alter HJ, Chalmers TC, Holland MD, Purcell RH, Alling DW, Young D, Frenkel LD, Lee SL, Lamson ME. A comparison of the frequency of hepatitis $B$ antigen and antibody in hospital in hospital and non-hospital personnel. N Engl J Med 1973;289:647-51.

- Limentani AE, Elliott LM, Noah ND, Lamborn JK. An outbreak of hepatitis B from tattooing. Lancet 1979;2:86-8.

- Liou TC, Chang TT, Young KC, Lin XZ, Lin CY, Wu HL. Detection of HCV RNA in saliva, urine, seminal fluid, and ascites. J Med Virol 1992;37:192-202.

- Long J, Allwright S, Barry J, Reynolds SR, Thornton L, Bradley F, Parry JV. Prevalence of antibodies to hepatitis B, hepatitis C, and HIV and risk factors in entrants to Irish prisons: a national cross sectional survey. BMJ 2001;323:1209-13.

- Lourenço R. Epidemiologia da infecção pelo VIH-1 nas instituições carcerárias masculinas do Complexo Penitenciário do Carandiru - São Paulo, SP. 1992. Dissertação (Mestrado) Escola Paulista de Medicina, Universidade Federal de São Paulo, 1992.

- Lu L, Li C, Fu Y, Thaikruea L, Thongswat S, Maneekarn N, Apichartpiyakul C., Hotta H, Okamoto H, Netski D, Pybus OG, Murphy D, Hagedorn $\mathrm{CH}$, Nelson KE.Complete genomes for hepatitis $\mathrm{C}$ virus subtypes $6 \mathrm{f}, 6 \mathrm{i}, 6 \mathrm{j}$ and $6 \mathrm{~m}$ : viral genetic diversity among Thai blood donors and infected spouses. J Gen Virol 2007;88:1505-18.

- Lunel F, Cadranel JF, Rosenheim M, Dorent R, Di-Martino V, Payan C, Fretz C, Ghoussoub JJ, Bernard B, Dumont B, Perrin M, Gandjbachkh I, Huraux JM, Stuyver L, Opolon P. Hepatitis virus infections in heart transplant recipients: epidemiology, natural history, characteristics, and impact on survival. Gastroenterology 2000;119:1064-74. 
- Macalino GE, Vlahov D, Sanford-Colby S, Patel S, Sabin K, Salas C, Rich JD. Prevalence and incidence of HIV, hepatitis B virus, and hepatitis $\mathbf{C}$ virus infection among males in Rhode Island Prisons. Am J Public Health 2004a;94:1218-23.

- Macalino GE, Hou JC, Kumar MS, Taylor LE, Sumantera IG, Rich JD. Hepatitis C infection and incarcerated populations. Int J Drug Policy 2004b;15:103-14.

- Mahoney FJ. Update on diagnosis, management, and prevention of hepatitis B virus infection. Clin Microbiol Rev 1999;12:351-66.

- Malliori M, Sypsa V, Psichogiou M, Touloumi G, Skoutelis A, Tassopoulos N, Hatzakis A, Stefanis C. A survey of bloodborne viruses and associated risk behaviours in Greek prisons. Addiction 1998;93:243-51.

- Martelli CM, Andrade Al, Cardoso DD, Sousa LC, Silva SA, Sousa MA, Zicker F. soroprevalência e fatores de risco para a infecção pelo vírus da hepatite $B$ pelos marcadores AgHBs e anti-HBs em prisioneiros e primo doadores de sangue. Rev Saúde Pública 1990;24:270-6.

- Massad E. HIVIAIDS no sistema prisional brasileiro. In: A epidemia de AIDS no Brasil - Situações e Tendências. Ministério da Saúde, 1997;87-104.

- Massad E, Rozman M, Azevedo RS, Silveira ASB, Takey K, Yamamoto Y I, Strazza L, Ferreira MMC, Carvalho HB, Burattini MN. Seroprevalence of HIV, HCV and syphilis in Brazilian prisoners: Preponderance of parenteral transmission. Eur $\mathbf{J}$ Epidemiol 1999;15:439-45.

- Matheï C, Buntinx F, Van Damme P. Seroprevalence of hepatitis C markers among intravenous drug users in western European countries: a systematic review. J Viral Hepat 2002;9:157-73.

- McCallum FO, Bauer DJ. Homologus serum hepatitis. Lancet 1947;ii 691-2. 
- Meheus A. Teenager's lifestyle and risk of exposure to hepatitis B virus. Vaccine 2000;18(suppl. 1):S26-S29.

- Memon MI, Memon MA. Hepatitis C: an epidemiological review. J Viral Hepat 2002;9:84-100.

- Mendel I, Muraine M, Riachi G, Forzli F, Bertin C, Colin R, Brasseur G, Buffet-Janvresse C. Detection and genotyping of the hepatitis C RNA in tear fliud from patients with chronic hepatitis C. J Med Virol 1997;51:231-3.

- Miller ER, Bi P, Ryan P. The prevalence of HCV antibody in South Australian prisoners. J Infect 2006;53:125-30.

- Minkoves R. Estudo da soroprevalência da hepatite B em 02 (duas) prisões da Cidade de São Paulo. 1992, 103p. Dissertação (Mestrado) - Departamento de Medicina, Escola Paulista de Medicina, São Paulo, 1992.

- Mitsui T, Iwano K, Masuko K, Yamazaki C, Okamoto H, Tsuda F, Tanaka T, Mishiro S. Hepatitis C virus infection in medical personnel after needlestick accident. Hepatology 1992;16:1109-14.

- Mosley JW, Edwards VM, Casey BS. Hepatitis virus infection in dentists. N Engl J Med 1975;293:729-34.

- Muñiz FJ, Malayska H, Levin WC. Au antigen in blood from prisoners. N Engl J Med 1971;284:501-2.

- Murray KF, Richardson LP, Morishima C, Owens JW, Gretch DR. Prevalence of hepatitis $C$ virus infection and risk factors in an incarcerated juvenile population: a pilot study. Pediatrics 2003;111:153-7.

- Ogasawara S, Kage M, Kosai K, Shimamatsu K, Kojiro M. Hepatitis C virus RNA in saliva and breastmilk of hepatitis C carrier mothers. Lancet 1993;341:561.

- Ohto H, Terezawa S, Sasaki N, Sasaki N, Hino K, Ishiwata C, Kako M, Ujiie $\mathrm{N}$, Endo $\mathrm{C}$, Matsui $\mathrm{A}$, Okamoto $\mathrm{H}$, Mishiro $\mathrm{S}$, The vertical transmission of hepatitis $\mathbf{C}$ virus collaborative study group. $\mathbf{N}$ Engl $\mathbf{J}$ Med 1994;330:744-50. 
- Okada K, Kainiyama I, Inometa M, Imai M, Miyakawa Y. e Antigen and anti-e in the serum of asymptomatic carrier mothers as indicators of positive and negative transmission of hepatitis $B$ virus in their infants. N Engl J Med 1976;294:746-9.

- Pallás JR, Fariñas-Álvarez C, Prieto D, Delgado-Rodriguez M. Coinfections by HIV, hepatitis $B$ and $C$ in imprisoned injecting drug users. Eur J Epidemiol 1999a;15:699-04.

- Pallás JR, Fariñas-Álvarez C, Prieto D, Llorca J, Delgado-Rodriguez M. Risk factors for monoinfections and coinfections with HIV, hepatitis $B$ and hepatitis $C$ viruses in northern Spanish prisoners. Epidemiol Infect 1999b;123:95-102.

- Paraná R, Almeida D. HBV epidemiology in Latin America. J Clin Virol 2005;34(suppl. 1):S130-S133.

- Passadouro R. Prevalência e factores de risco das VIH, hepatite B e C num estabelecimento prisional de Leiria. Acta Med Port 2004;17:3814.

- Piot P, Quinn TC, Taelman H, Feinsod FM, Minlangu KB, Wobin O, Mbendi N, Mazebo P, Ndangi K, Stevens $\mathrm{W}$, et al. Acquired immunodeficiency syndrome in a heterosexual population in Zaire. Lancet 1984;2:65-9.

- Poulin C, Alary M, Lambert G, Godin G, Landry S, Gagnon H, Demers E, Morarescu E, Rochefort J, Claessens C. Prevalence of HIV and hepatitis C vírus infections among inmates of Quebec provincial prisons. CMAJ 2007;177:252-6.

- Prince AM, Brotman B, Grady GF, Kuhns WJ, Hazzi C, Levine RW, Millian SJ. Long-incubation post-transfusion hepatitis without serological evidence of exposure to hepatitis-B virus. Lancet 1974;2:241-6.

- Prince AM. An antigen detected in the blood during the incubation period of serum hepatitis. Proc Natl Acad Sci USA 1968a;60:814-21.

- Prince AM. Relation of Australia and SH antigens. Lancet 1968b;2:462-3. 
- Redd JT, Baumbach J, Kohn W, Nainan O, Khristova M, Williams I. Patient-to-patient transmission of hepatitis B virus associated with oral surgery. J Infect Dis 2007;195:1311-14.

- Reindollar RW. Hepatitis C and correctional population. Am J Med 1999;107(suppl. 2):S100-S103.

- Resti M, Azzari C, Mannelli F, Moriondo M, Novembre E, Martino M, Vierucci $A$ and Tuscany study group on hepatitis $C$ virus infection on children. Mother to child transmission of hepatitis $C$ virus: Prospective study of risk factors and timing of infection in children born to women seronegative for HIV-1. BMJ 1998;317:437-41.

- Reuben A. Landmarks in hepatology - The thin red line. Hepatology 2002;36(3):770-3.

- Robinson WS. Hepatitis B virus e Hepatitis D virus. In: Mandell GL; Bennett JE; Douglas RG, editors. Principles and Practice of Infectious Diseases $5^{\text {th }}$ ed., New York; 2000.

- Rodríguez-Méndez ML, González-Quintela A, Aguilera A, Carballo E, Barrio E. Hepatogastroenterology 2003;50):2093-7.

- Rosenheim M, Cadrane JF, Stuyver L, Dorent R, Golliot F, Astagneau P, Di Martino V, Delcourt A, Gandjbakhch I, Huraux JM, Lunel F. Nosocomial transmission of hepatitis $B$ virus associated with endomyocardial biopsy. Gastroenterol Clin Biol 2006;30:1274-80.

- Ross L, Kohler CL, Grimley DM, Bellis J. Intention to use condoms among three low-income, urban African American subgroups: cocaine users, noncocaine drug users, and non-drug users. J Urban Health 2003;80:147-60.

- Rotily M, Vernay-vaisse C, Bourliére M, Galinier-Pujol A, Rousseau SO. HBV and HIV screening and hepatitis B immunization programme in the prison of Marseille, France. Int J STD AIDS 1997;8:753-9. 
- Roudot-Thoraval F, Pawlotsky JM, Thiers V, Deforges L, Girollet PP, Guillot F, Huraux C, Aumont P, Brechot C, Dhumeaux D. Lack of mother-to-infant transmission of hepatitis $C$ virus in human immunodeficiency virus-seronegative women: a prospective study with hepatitis C virus RNA testing. Hepatology 1993;17:772-7.

- Ruiz JD, Molitor F, Sun RK, Mikanda J, Facer M, Colford JM, Rutherford GW, Ascher MS. Prevalence and correlates of hepatitis C virus infection among inmates entering the California Correctional System. West J Med 1999;170:156-60.

- Sabol WJ, Minton TD, Harrison PM. Bureau of Justice Statistics Bulletin. Prison and jail inmates at Midyear 2006. $2003 \mathrm{NCJ}$ 217675. Disponível em www.ojp.usdoj.gov/bjs/pub/pdf/pjim06.pdf Acessado em 06/10/2007.

- Samuel MC, Bulterys M, Jenison S, Doherty P. Tattoos, incarceration and hepatitis $B$ and $C$ among sreet-recruited injection drug users in New Mexico, USA: update. Epidemiol Infect 2005;133:1146-8.

- Sanchez ZM, Nappo SA. Seqüência de drogas consumidas por usuários de crack e fatores interferentes. Rev Saúde Pública 2002;36:420-30.

- Santos AK, Ishak MO, Santos SE, Ishak R. A possible correlation between the host genetic background in the epidemiology of hepatitis $B$ virus in the Amazon Region of Brazil. Mem Inst Oswaldo Cruz 1995;90:435-41.

- São Paulo. Secretaria da Administração Penitenciária. População carcerária do Estado de São Paulo - Ano de 2006. 2006 Dez. Disponível em http://www.sap.sp.gov.br/common/dti/estatisticas/populacao mensal.h tm Acessado em 11/11/2007.

- Sartori M, La Terra G, Aglietta M, Manzin A, Navino C, Verzetti G. Transmission of hepatitis $\mathbf{C}$ via blood splash into conjunctiva. Scand J Infect Dis 1993;25:270-1. 
- Schmunis GA, Zicker F, Pinheiro F, Brandling-Bennett D. Risk for transfusion-transmitted infectious diseases in Central and South America. Emerging Infec Dis 1998;4:1-12.

- Sharma AK, Aggarval OP, Dubey KK. Sexual behavior of drug-users: is it different? Prev Med 2002;34:512-5.

- Shepard CW, Simard EP, Finelli L, Fiore AE, Bell PB. Hepatitis B virus infection: epidemiology and vaccination. Epidemiol Rev 2006;28:11225.

- Shepard CW, Finelli L, Alter MJ. Global epidemiology of hepatitis C virus infection. Lancet Infect Dis 2005;5:558-67.

- Silveira TR, Fonseca JC, Rivera L, Fay OH, Tapia R, Santos JI, Urdeneta E, Clemens SA. Hepatitis seroprevalence in Latin América. Rev Panam Salud Publica 1999;6:378-83.

- Singh S, Prasad R, Mohanty A. High prevalence of sexually transmitted and blood-borne infections amongst the inmates of a district jail in Northern India. Int J STD AIDS 1999;10:475-8.

- Smith $\mathrm{Cl}$, Patterson F, Goulston KJ, Chapuis PH, Chapman G, Tait $A D$. Evidence of hepatitis virus infection among Australian prisoners war during World War II. Med J Aust 1987;147:229-30.

- Sodeyama T, Kiyosawa K, Urushihara A, Matsumoto A, Tanaka E, Furuta S, Akahane $\mathrm{Y}$. Detection of hepatitis $\mathrm{C}$ virus markers and hepatitis C virus genomic-RNA after needlestick accidents. Arch Intern Med 1993;153:1565-72.

- Solomon L, Flynn C, Muck K, Vertefeuille J. Prevalence of HIV, syphilis, hepatitis B, and hepatitis C among entrants to Maryland correctional facilities.

J Urban Health 2004;81:25-37.

- StataCorp. 1999. Stata Statistical Software: release 6.0. College Station, Texas: Stata Corporation;1999.

- Stevens CE, Beasley RP, Tsui J, Lee WC. Vertical transmission of hepatitis B antigen in Taiwan. N Engl J Med 1975;292:771-4. 
- Strazza L, Massad E, Azevedo RS, Carvalho HB. Estudo de comportamento associado ä infecção pelo HIV e HCV em detentas de um presídio de São Paulo, Brasil. Cad Saúde Pública 2007;23:197205.

- Tanaka J. Hepatitis B epidemiology in Latin America. Vaccine 2000;18:S17-S19).

- Tedder RS, Gilson RJ, Briggs M, Loveday C, Cameron CH, Garson JA, Kelly GE, Weller IV. Hepatitis C virus: evidence for sexual transmission. BMJ 1991;302:1299-302.

- Thomas DL, Lemon SM.. Hepatitis C. In: Mandell GL; Bennett JE; Douglas RG, editors. Principles and Practice of Infectious Diseases $5^{\text {th }}$ ed., New York; 2000.

- Thomas DL, Villano SA, Riester K, Hershow R, Mofenson LM, Landesman SH, Hollinger FB, Davenny K, Riley L, Diaz C, Tang HB, Quinn TC. Perinatal transmission of hepatitis $C$ virus from human immunodeficient virus type 1-infected mothers. J Infect Dis 1998;177:1480-8.

- Tourinho DR, Dourado I. Safe sex in the prison system in Salvador, Brazil: it is possible? In: International AIDS Conference, XIV, 2002, Barcelona. Anais eletrônico Disponível em: http://www.aids2002.com/include/printabstract $\quad$ Acessado em 31/08/2003.

- Treitinger A, Spada C, Ferreira LA, Neto MS, Reis M, Verdi JC, de Miranda AF, de Oliveira OV, Van der Sander Silveira M, Abdalla DS. Hepatits $B$ and hepatitis $C$ prevalence among blood donors and HIV-1 infected patients in Florianópolis-Brazil. Braz J Infect Dis 2000;4:1926.

- Tsang THF, Horowitz E, Vugia DJ. Transmission of hepatitis C through tattooing in a United States Prison. Am J Gastroenterol 2001;96:1304-5. 
- Tucker RM, Gaffey MJ, Fisch MJ, Kaiser DL, Guerrant RL, Normansell DE. Seroepidemiology of hepatitis D (delta agent) and hepatitis B among Virginia State prisoners. Clin Ther 1987;9:622-8.

- UNAIDS - Joint United Nations Programme on HIVIAIDS and World Health Organization (WHO). Eastern Europe and Central Asia. Fact Sheet 2002. 2002;dec:1-2.

- Utsumi T, Hashimoto E, Okumura Y, Takayanagi M, Nishikawa H, Kigawa M, Kumakura N, Toyokawa $\mathrm{H}$. Heterosexual activity as a risk factor for the transmission of hepatitis $C$ virus. J Med Virol 1995;46:122-5.

- Vazquéz-Martínez JL, Coreño-Juárez MO, Montaño-Estrada LF, Attlan M, Gómez-Dantés H. Seroprevalence of hepatitis $B$ in pregnant women in Mexico. Salud Publica Mex 2003;45:165-70.

- Veronesi R, Camargo Filho FC, Schechtmann M, Neitzer E, Souza LNX, Zampieri G, Franco BN, Santos O. Aids entre presidiários brasileiros: considerações sobre o possível papel dos vírus HTLV-1 e HBV como co-fatores implicados na patogênese da Aids. Rev Bras Med 1993;50:488-95.

- Vlahov D, Nelson KE, Quinn TC, Kendig N. Prevalence and incidence of hepatitis $C$ virus infection among male prison inmates in Maryland. Eur J Epidemiol 1993;9:566-9.

- Wasley A, Alter MJ. Epidemiology of hepatitis C: Geographic differences and temporal trends. Semin Liver Dis 2000;20:1-16.

- Weild AR, Gill ON, Bennett D, Livingstone SJM, Parry JV, Curran L. Prevalence of HIV, hepatitis $B$, and hepatitis $C$ antibodies in prisoners in England and Wales: a national survey. Commun Dis Public Health 2000;3:121-6.

- Weinbaum CM, Sabin KM, Santibanez SS. Hepatitis B, hepatitis C, and HIV in correctional populations: a review of epidemiology and prevention. AIDS 2005;19(suppl 3):S41-S46. 
- Weiner AJ, Thaler MM, Crawford K, Ching K, Kansopon J, Chien DY, Hall JE, Hu F, Houghton M. A unique, predominant hepatitis C virus variant found in a infant born to a mother with multiple variants. $\mathbf{J}$ Virol 1993;67:4365-8.

- Werner BG, Grady GF. Accidental hepatitis-B-surface-antigen-positive inoculations: use of e antigen to estimate infectivity. Ann Intern Med 1982;97:367-9.

- Wolfe MI, Xu F, Patel P, O'Cain M, Schillinger JA, St Louis ME, Finelli L. Am J Public Health 2001;91:1220-5.

- Wong PN, Fung TT, Mak SK, Lo KY, Tong GM, Wong Y, Loo CK, Lam EK, Wong AK. Hepatitis virus infection in dialysis patients. J Gastroenterol Hepatol 2005;20:1641-51.

- World Health Organization. Hepatitis C: global prevalence. Weekly Epidemiological Record Geneva, Switzerland 1999;74:421-8.

- Xu ZY, Liu CB, Francis DP, Purcell RH, Gun ZL, Duan SC, Chen RJ, Margolis SM, Huang $\mathrm{CH}$, Maynard JE the United States-China Cooperative Study Group on Hepatitis B. Prevention of perinatal acquisition of hepatitis $B$ virus carriage using vaccine: preliminary report of a randomized, double-blind placebo-controlled and comparative trial. Pediatrics 1985;76:713-8.

- Yeung LT, King SM, Roberts EA. Mother-to-infant transmission of hepatitis C virus. Hepatology 2001;34:223-9.

- Zanetta DMT, Stazza L, Azevedo RS, Carvalho HB, Massad E, Menezes RX, Ferreira DP, Burattini MN. HIV infection and related risk behaviors in a disadvantaged youth institution of São Paulo, Brazil. Int J STD AIDS 1999;10:98-104.

- Zanetti AR, Tanzi E, Newell ML. Mother-to-infant transmission of hepatitis C virus. J Hepatol 1999;31(suppl 1):96-100. 
APÊNDICE 1 


\title{
HOSPITAL DAS CLÍNICAS DA FACULDADE DE MEDICINA DE RIBEIRÃO PRETO DA UNIVERSIDADE DE SÃO PAULO TERMO DE CONSENTIMENTO PÓS-INFORMACÃO
}

\author{
NOME DA PESQUISA: \\ "PREVALÊNCIA E FATORES DE RISCO PARA A INFECÇÃO DO \\ HIV NA POPULAÇÃO CARCERÁRIA MASCULINA DA PENITENCIÁRIA DE \\ RIBEIRÃO PRETO.
}

\section{PESQUISADOR RESPONSÁVEL:}

\section{Dr. HARNOLDO COLARES COELHO CRM 80946}

\section{INFORMAÇOES DADAS AOS PACIENTES:}

1. O Sr. está sendo convidado a participar de uma pesquisa para saber quem está contaminado com o vírus da AIDS, com o vírus da hepatite $\mathrm{B}$, com 0 vírus da hepatite $C$ e com a sífilis.

2. Estas doenças são muito encontradas nos presos das cadeias de todo o país.

3. A AIDS se pega em relação sexual sem camisinha ou tomando sangue contaminado quando a pessoa é internada em hospital e tomando pico na veia com a mesma agulha que foi usada por muitas pessoas. A hepatite $B$ se pega da mesma maneira da AIDS. A hepatite $C$ se pega em tomando pico na veia com a mesma agulha que foi usada por muitas pessoas e tomando sangue contaminado em hospital. A sífilis se pega em relação sexual sem camisinha.

4. O vírus da AIDS causa queda da resistência da pessoa e ela pode ficar doente com várias infecções. Os vírus da hepatite $B$ e da hepatite $C$ causam inflamação no fígado e pode deixar a pessoa doente toda amarelada ou não. A sífilis é uma doença que se pega na relação sexual e pode causar feridas no pinto, na boca e manchas em todo corpo.

5. As pessoas podem ter qualquer um desses bichinhos que causam essas doenças e não sentir nada e nem ter nenhuma alteração no corpo. Dessa maneira, quem estiver contaminado vai poder se tratar antes de ficar doente se fizer os exames adequados.

6. Para fazer esses exames o Sr. vai ter que tirar sangue do braço. O Sr. vai sentir uma pequena dor no local da picada como se fosse tomar uma injeção. Vai ser tirado um tanto de sangue que cabe mais ou menos numa colher de sopa. Nos tubinhos que tiver o seu sangue vai ter um número e a primeira letra do seu nome e do seu sobrenome. Ninguém fora da cadeia vai saber que o Sr. fez exames. Nós garantimos que o resultado será dado só para o Senhor.

7. Essa pesquisa pode beneficiar o Sr., porque se nós descobrirmos uma dessas infecções no seu sangue, nós encaminharemos para tratamento adequado. Além disso, os resultados da pesquisa poderão, no futuro, fazer com que as autoridades possam estabelecer maneiras de prevenir e tratar outras pessoas.

8. O Senhor participará da pesquisa se quiser, podendo desistir a qualquer momento, sem que isso o prejudique. 


\title{
TERMO DE CONSENTIMENTO
}

$\mathrm{Eu}$,

após tomar conhecimento sobre o projeto "Prevalência e fatores de risco para a infecção do HIV na população carcerária masculina da Penitenciária de Ribeirão Preto", entendi e concordo em participar da pesquisa, autorizando a coleta de uma amostra de meu sangue para estudo dessas doenças, cujos resultados poderei conhecer e aos quais terei acesso individual e sigiloso. Autorizo a utilização e divulgação dos resultados, embora exija sigilo absoluto quanto á minha identidade.

OBS: O estudo me oferece também a pesquisa de marcadores para Hepatites B e C, também de modo sigiloso.

Ribeirão Preto de de

\author{
PESQUISADOR RESPONSÁVEL \\ Dr. Harnoldo Colares Coelho \\ Cremesp 80946 \\ Fone de contato 602-2695
}


APÊNDICE 2 


\section{QUESTIONÁRIO}

DATA _ I I -

1. NOME

2. NASCIMENTO

IDADE $\square$

3. ESTADO CIVIL

1.casado 2. solteiro 3. amasiado

4. viúvo 5.

Divorc./separ.

4. FILHOS

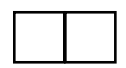

5. LOCAL NASC.

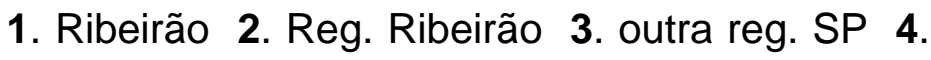
outro estado

6. LOCAL RESID. outro estado

1. Ribeirão 2. Reg. Ribeirão 3. outra reg.SP 4.

7. ESCOLARIDADE

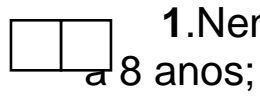

1.Nenhuma; 2. até 2 anos; 3. 2 a 5 anos; 4.5

5. colegial incompleto; 6. colegial completo; 7. superior incompleto;

8. superior completo

8. TEMPO TOTAL DA PENA

9.TEMPO JÁ CUMPRIDO

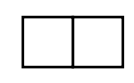

10. JÁ INTERNOU EM REFORMAT./FEBEM

1. sim; 2. não; 3. não sabe

11. DSTS PRÉVIA ULCERATIVA

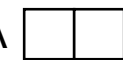

1. não; 2. uma vez;

3. mais de uma vez

12. ONDE TRATOU

1.médico;

2. não tratou;

3. não se aplica 
13. DSTs PRÉVIA NÃO ULCERATIVA $\square \square$ 1.não; 2. uma vez; 3. mais de uma vez

14. ONDE TRATOU

15. CIRCUNCIDADO 1.médico; 2. não tratou; 3 . não se aplica

1. sim; 2. não

16. TATUAGEM

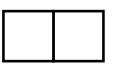

1. sim; 2. não

17. PIERCING 1. sim; 2. não; 3. não sabe

18. JÁ FEZ TESTE ANTI-HIV $\square \square$ 1. não; 2. uma vez; 3. mais de uma vez; 4. ñ sabe

19. RESULTADO

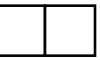

1. positivo;

2. negativo; 3.

3. não sabe; 4. não se aplica

20. TRANSF. SANGUÍNEA

1. não 2. uma vez 3. mais de uma vez 4.não sabe

21. SEXO COM USUÁRIOS DE DROGAS

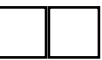

1. sim;

2. não; 3. não sabe

22. USO DE DROGAS ILÍCITAS NÃO INJETÁVEIS AGORA OU PASSADO $\square \square$ 1. sim; 2. não 3. não sabe QUE TIPO

23. USO DE DROGAS ILÍCITAS INJETÁVEIS NO PASSADO

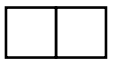

1. freqüentemente; 2 . às vezes; 3 .raramente; 4. uma vez; 5 . nunca; 6 não se aplica 
24. QUANTO TEMPO DE USO

1. mais de 5 anos; 2. 3 a 5 anos; 3.1 a 3 anos; 4. menos de 1 ano;

5. não se aplica

25. COMPARTILHAMENTO NO PASSADO DE AGULHAS/SERINGAS PARA USO DE DROGAS ILÍCITAS

1. freqüentemente; 2. às vezes; 3.raramente; 4. uma vez; 5. nunca;

6. não se aplica

26. USO ATUAL DE DROGAS ILÍCITAS INJETÁVEIS

1. freqüentemente; 2 . às vezes; 3 . raramente; 4. uma vez; 5. nunca ;

6. não se aplica

27. COMPARTILHAMENTO ATUAL DE AGULHAS/SERINGAS PARA USO DE DROGAS ILÍCITAS

1. freqüentemente; 2 . às vezes; 3.raramente; 4. uma vez; 5. nunca;

6. não se aplica

28. PREFER. SEXUAL $\square$ 1. Heterossex.; 2. Homossex.; 3. Bissex.;

4. Desconhecido

29. QUANTOS PARCEIROS TEVE UM ANO ANTES DA PRISÃO

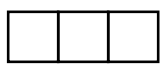

30. VISITA ÍNTIMA $\square \square$ 1. sim; 2. não

31. USO DE PRESERVATIVO NA VISITA ÍNTIMA

1. sempre; 2. às vezes; 3. nunca; 4. não se aplica

32. SEXO C/ COLEGAS NA PRISÃO

1. freqüentemente; 2. às vezes; 3. raramente; 4. uma vez; 5. nunca ;

6. não sabe 
33. FORMA $\square$. ativo 2. Pas.. 3. ativo/pas. 4. só oral 5. só masturb.; 6. não se aplica

34. USO DE PRESERVATIVO QUANDO FAZ SEXO COM COLEGAS 1. sempre; 2. às vezes; 3. nunca; 4. não se aplica 35. JÁ TEVE ICTÉRICIA 1. sim; 2. não; 3. não sabe 36. JÁ TEVE HEPATITE 1. sim; 2. não; 3. não sabe 37. USO DE TABACO 1. sim; 2. não; 3. não sabe

\section{Resultados de exames para hepatite B e hepatite C} HBsAg $\square \square$ 1. reagente; 2. não reagente; 3. Indeterminado Anti-HBs $\square \square$ 1. reagente; 2. não reagente; 3. Indeterminado Anti-HBc total $\square \square$ 1. reagente; 2. não reagente; 3. Indeterminado Anti-HCV $\square \square$ 1. reagente; 2. não reagente; 3. Indeterminado 